\title{
Análise socioeconômica dos sistemas de uso de terra por pequenos produtores agrários na Amazônia oriental
}

Thomas Hurtienne - Professor e pesquisador do Núcleo de Altos Estudos da Amazônia/ UFPA.

\section{Resumo}

O objetivo deste artigo é observar a dinâmica dos sistemas de uso agrícola por pequenos proprietários de terra ao nordeste do estado do Pará. No intuito de relacionar formas específicas de agricultura itinerante e de indústria extrativa na Amazônia com os processos endógenos de tomada de decisão econômica. Teve repercussão sobre a dinâmica destes sistemas e as políticas governamentais que a partir de 1970 voltaram-se para a modernização agrícola e a criação de lavouras permanentes, contribuindo para que fossem atingidas barreiras agroecológicos e agroeconômicas. Com base nessas novas dinâmicas, os pequenos empreendimentos familiares na Amazônia defrontam-se com ações públicas e privadas que fragilizam essa estabilidade.
Palavras-chave

Política Produtiva, Amazônia.

\section{Abstract}

This article examines the dynamics of agricultural systems used by small farmers in the northeast of the State of Pará (Brazil). Its goal is to relate specific forms of shifting cultivation and extractive industry in Amazonia with endogenous processes of economic decision making. It has resonated on the system dynamics, and public policies, which as of the 70's have focused on agricultural modernization and creation of permanent crops, thus contributing to the achievement of agro-ecologic and agro-economic barriers. Based on the new dynamics, small family enterprises in Amazonia have to cope with public and private actions, which undermine their stability.

\section{Keywords}

Public policies, Amazonia. 


\section{INTRODUÇÃO}

Todas as análises detalhadas da dinâmica do sistema de uso de terra por pequenos produtores agrários, que tentaram relacionar o contexto agroecológico e socioeconômico com os processos internos de tomada de decisão econômica na Amazônia, especialmente no Noroeste do Pará, têm enfrentado o problema da inexistência de uma base de dados suficiente.

Isso afeta a caracterização dos agroecossistemas dos pequenos produtores agrários existentes em antigos assentamentos e em fronteiras agrícolas mais recentes e de sua sustentabilidade socioeconômica e ecológica, em comparação com outros sistemas agrícolas de uso de terra (FEARNSIDE, 1988a; RUTHENBERG, 1980; SERRÃO; HOMMA, 1993). A té o momento, um dos grandes problemas é o indiscriminado uso do conceito de slash-and-burn shifting cultivation ou agricultura itinerante ou nômade para caracterizar diversos sistemas de uso da terra (BURGER; KITAMURA, 1987; CAMARGO, 1948a; GOUROU, 1950; KITAMURA, 1982; PENTEADO, 1967; SERRÃ O; HOMMA, 1993; WORLD BANK, 1992). Assim, sistemas contrastantes de uso da terra, como os utilizados pelos grupos indígenas, pelos grupos dispersos ao longo dos rios (os caboclos ou ribeirinhos), pelos colonos da Zona Bragantina e pelos colonos vindo do sul e do nordeste brasileiro para as regiões de fronteira agrária, têm sido representados como um conjunto homogêneo sob a denominação um tanto vaga de agricultura itinerante (COSTA, 1989; PARKER, 1985; SAWYER, 1979a).

Por muito tempo, a agricultura itinerante e a indústria extrativa, próprias da economia primitiva da idade da pedra, foram vistas como responsáveis pela falta de desenvolvimento socioeconômico na Amazônia (GOUROU, 1950; MAHAR, 1978; WAGLEY, 1953). As políticas governamentais de modernização tentaram, em diversos momentos, introduzir uma agricultura "ordenada" na Amazônia, à imagem daquela existente na Europa e no Sul do Brasil (COSTA, 1992a). Uma vez que tais iniciativas falharam - mais espetacularmente no caso da Transamazônica - por volta da década de 70, espalhou-se a opinião de que as formas tradicionais de uso da terra, praticadas pelos grupos indígenas e pelos caboclos, caracterizadas por uma combinação de produtos extrativos florestais e de cultivo pós-queimada, seriam ecológica e economicamente sustentáveis devido à baixa densidade populacional e a uma limitada integração de mercado com baixos níveis de produção (MORAN, 1981; SMITH, 1982). 0 resultado foi que a agricultura itinerante de roçado foi associada a uma imagem negativa de ineficiência econômica e de ecologia não sustentável, especialmente nas regiões de assentamentos mais antigos, como a Zona Bragantina, 
e nas áreas de assentamentos mais novos, próximas às agrofronteiras, onde a densidade populacional e o acesso ao mercado já havia atingido - ou poderia atingir brevemente - a capacidade de carga (ALVIM, 1977; FEARNSIDE, 1986).

Na fase forçada de modernização agrícola, a partir dos anos 70, tal opinião serviu para legitimar a) a promoção unilateral de grandes empreendimentos pecuários e de plantações permanentes de porte médio mediante vultosas transferências e subvenções, distribuídas pelas agências governamentais de desenvolvimento, como a Superintendência de Desenvolvimento da Amazônia (SUDAM) e o Banco da Amazônia S.A. (BASA), e b) o trabalho unilateral de pesquisa agrícola feito pela Empresa Brasileira de Pesquisa Agropecuária (EMBRAPA) e pela Empresa de Assistência Técnica e Extensão Rural (EMATER), centralizado na modernização agrícola intensiva em capital, especialmente com os pacotes tecnológicos da Revolução Verde (HALL, 1989; BROWDER, 1988; HECHT, 1983, 1985).

A expansão de áreas de pastagem para o gado, subsidiada pelo governo, e os parcos resultados econômicos nas áreas produtivas levaram a um gigantesco desastre ecológico: mais da metade das áreas de floresta primária destruída nas décadas de 70 e 80 para abrir caminho às pastagens estava tão degradada após o primeiro ciclo de 6-8 anos que as terras tiveram de ser abandonadas, enquanto o restante das áreas tornava-se não lucrativa, com uma densidade de apenas 0,5 cabeças de gado por hectare (BUSCHBACHER; UHL; SERRÃO, 1988). A pecuária extensiva representa apenas um caso particular de agricultura itinerante (WORLD BANK, 1992).

O inegável fracasso da modernização agrícola por parte das grandes empresas agropecuarias levou a EMBRAPA-CPATU a limitar o desenvolvimento da pecuária ao uso intensivo de áreas já degradadas. Após 1990, sem a disponibilidade dos grandes subsídios, essa intensificação foi possível apenas com a ajuda do rendimento obtido com a extração de toras das reservas de floresta residual, ou por meio de novos programas de crédito subsidiado (desde 1991), como o FNO (um fundo de desenvolvimento para a Amazônia, administrado pelo BASA) (BASA, 1997; MATTOS; UHL, 1994). O programa de crédito parece ter levado a uma rápida expansão de áreas de fazenda, de propriedade de grandes famílias, ao longo da Transamazônica e em Marabá.

Com a insustentabilidade das grandes fazendas de gado, os esforços de modernização feitos pelos órgãos governamentais voltaramse, no início dos anos 80, para a promoção da lavoura permanente em empresas de porte médio, intensivas no uso de capital, e, temporariamente, para as empresas familiares no Nordeste do Pará. Como vere- 
mos mais detalhadamente a seguir, assim como o ciclo extensivo da pecuaria, o cultivo permanente em grandes áreas também leva a um drástico crescimento de doenças causadas por fungos e ao aparecimento de plantas daninhas após 6 ou 8 anos. J unto com a queda dos preços no mercado de pimenta e cacau, a segunda parte dos planos governamentais de modernização atingiu barreiras agroecológicas e agroeconômicas, reforçadas pelos programas de apoio governamental.

Essas duas alternativas para a agricultura itinerante extensiva, concebidas como formas sustentáveis de uso da terra, provaram ser ainda menos sustentáveis do que se imaginava.

Somente após a agromodernização forçada ter-se tornado indesejável, os segmentos de agricultura itinerante que haviam se desenvolvido discretamente durante a década de 80 , dentro de empreendimentos familiares estáveis com integração parcial de lavouras permanentes, em áreas relativamente pequenas, voltaram à cena (COSTA, 1995; KITAMURA et. al., 1983). Apesar do crescente interesse por pequenos empreendimentos agrícolas de propriedade familiar, no início da década de 90 não havia uma clara distinção entre os diferentes tipos de pequenos agricultores, tanto nos antigos assentamentos como nos mais novos, de diferentes épocas, próximos às agrofronteiras. As tipologias (categorias) propostas especialmente por Sawyer (1979) e Costa (1989, 1992a), mas também por Fearnside (1985) jamais foram bem desenvolvidas e, mais do que isso, foram implementadas com dificuldade.

Na análise da situação da pesquisa e das estratégias de intervenção, realizada por Serrão e Homma (1993) para o Conselho Nacional de Pesquisa dos Estados Unidos, foi salientada a importância da agricultura itinerante como um sistema de uso da terra para a produção agrícola na região. Quase meio milhão de empreendimentos de agricultura itinerante foi identificado. Com exceção de algumas referências à Zona Bragantina e a regiões tradicionais de agrofronteira, a velha imagem da agricultura itinerante como um sistema de produção de subsistência, de baixa produção, caracterizado pela dependência da fertilidade natural do solo e do trabalho manual, ainda dominava o texto (KITAMURA, 1994). Para atender a necessidade de melhoria nas formas de lavoura para a região, alguns autores, o Banco Mundial e o Instituto do Homem e Meio Ambiente da Amazônia (IMAZON) propuseram como modelo o sistema de produção agroflorestal artificial e diversificado de Tomé-Açu, aliado a diversos cultivos permanentes e ao uso de mão-de-obra exter-

${ }^{1}$ Instituto independente de pesquisa, localizado em Belém, que trabal ha com questões agrícolas e florestais.

190 
na à propriedade e de fertilizantes (SUBLER; UHL, 1990; TONIOLO; UHL, 1996; WORLD BANK, 1992).

Projetos de pesquisa realizados primeiramente pela EMBRAPA e pelo Deutsche Gesellschaft Fur Technische Zucammenarbeit (GTZ) e, mais tarde, pelo Programa SHIFT (DENICH, 1989; DENICH; VLEK; FÖLSTER, 1995; EMBRAPA-CPATU; GTZ, 1986) fizeram um levantamento inicial das características dos agroecossistemas no trópico úmido. Esses projetos de pesquisa visavam determinar o papel do crescimento secundário no ciclo de pousio nos campos itinerantes de pequenos agricultores da Zona Bragantina (inicialmente em Capitão Poço e IgarapéAçu e depois somente em Igarapé-Açu).

Os resultados obtidos tornaram claro que uma detalhada análise socioeconômica dos sistemas de uso da terra utilizados pelos pequenos agricultores na Amazônia oriental deve servir de referência para estudos análogos sobre ecologia tropical. Com base nesses resultados, as formas específicas de uso da terra para fins agrícolas no trópico úmido e especialmente as utilizadas na Amazônia podem ser mais bem entendidas e satisfatoriamente analisadas em conjunto com fatores socioeconômicos.

Antes de estudar os resultados do Programa SHIFT de Göttingen e de concordar com outros estudos semelhantes, particularmente os de Nepstad e Vieira, devemos esboçar as características mais importantes da clássica visão ecológica tropical, que ainda embasa a análise das formas de uso agrícola da terra no trópico úmido.

\section{A clássica visão ecológica tropical}

A visão da ecologia tropical tornou-se um modelo explicativo coerente somente após a Segunda Guerra Mundial. De acordo com esse modelo, os ecossistemas no trópico úmido, especialmente os da Amazônia, funcionam como reguladores do clima global (CAUFIELD, 1987; J ORDAN, 1982, 1985a; RICHARDS, 1952; SIOLI, 1984c; WHITMORE, 1975, 1993). Somente após o reconhecimento dos perigos ambientais globais, como o efeito estufa, causado pelo aumento dos níveis de $\mathrm{CO}_{2}$ na atmosfera, e as mudanças globais do clima, é que as organizações internacionais e os órgãos responsáveis pelas políticas de desenvolvimento passaram a aceitar esse modelo. Um dos pontos principais desse modelo entrava em conflito com a supervalorização do potencial agrícola nos solos ${ }^{2}$ do trópico úmido, que estava na origem das

2 A vegetação luxuriante e a grande produção de biomassa nas florestas tropicais do trópico úmido motivaram esse exagero. 
diversas tentativas de forçar a modernização da agricultura na Amazônia (SIOLI, 1973, 1984).

O modelo ecológico tropical das condições funcionais especiais dos ecossistemas no trópico úmido é baseado nas seguintes suposições ${ }^{3}$ :

1. A alta diversidade de espécies e de biomassa na floresta amazônica deve-se mais às condições bastante vantajosas de crescimento existentes nos climas úmidos tropicais, como abundância de radiação solar, alta produção de carboidratos por meio da fotossíntese, temperaturas regularmente altas, altas taxas de precipitação e ausência de inverno, do que à existência de solos ricos em nutrientes. (SIOLI, 1984; REICHHOLF, 1990).

2. A maior parte dos solos amazônicos é extremamente pobre, possuindo baixo CEC e baixo pH (COCHRANE; SANCHEZ, 1982; FALESI, 1974a; SOMBROEK, 1966; WEISCHET; CAVIEDES, 1993), devido à sua idade geológica e a intensos processos de exposição às intempéries.

3. A imensa quantidade de biomassa e a dinâmica de crescimento das florestas amazônicas têm por base os eficientes mecanismos de reciclagem biológica, os quais mantêm os nutrientes essenciais em um ciclo acima do solo, dentro da biomassa (COCHRANE; SANCHEZ, 1982; FALESI, 1974b; SOMBROEK, 1966; WEISCHET; CAVIEDES, 1993). Com exceção do fósforo (P) e do nitrogênio (N), geralmente bem menos de $50 \%$ dos cátions de nutrientes encontram-se nos solos das florestas tropicais, ao passo que $60 \%$ deles são encontrados nos solos das florestas temperadas da Europa e no nordeste da América do Norte (STARK; J ORDAN, 1978; WENT; STARK, 1968). Um ciclo eficiente de nutrientes dentro da biomassa requer bastante energia solar, o que permite também ciclos regionais de precipitação bastante diferentes daqueles encontrados em regiões temperadas (REICHHOLF, 1990). Esse "pequeno" ciclo, por meio da evapotranspiração, (SALATI; VOSE, 1984) é responsável por até dois terços da precipitação em florestas tropicais. A grande atividade de fotossíntese nas florestas tropicais úmidas leva a uma superprodução de produtos do carbono e carboidratos e, devido ao

3 Ver CAMARGO, 1948b; J ORDAN, 1985, 1989; KLINGE et al., 1975; MEGGERS, 1954, 1971; SIOLI, 1956, 1973, 1983, 1984b. Para uma visão geral, ver HURTIENNE, 1988, 1993; REICHHOLF, 1990; ROOSEVELT, 1980; WEISCHET, 1980.

192 
Análise socioeconômica dos sistemas de uso de terra por pequenos produtores agrários na Amazônia oriental

limitado fornecimento de nutrientes, a uma baixa produção de proteína (ROOSEVELT, 1980). A proporção de biomassa animal fica, portanto, em menos de 1\% (KLINGE, 1973a).

4. Quando as florestas e os prados das zonas temperadas são convertidos em áreas agrícolas, os solos geralmente mantêm sua estrutura e seu conteúdo de nutrientes originais (WEISCHET, 1980). Os agroecossistemas emergentes podem tornar-se "monoculturas" bastante especializadas com plantas em fileiras, por meio da eliminação da competição natural provocada pela mecanização do processo de cultivo do solo e pela aplicação de agrotóxicos (NORGAARD, 1981). 0 sistema de cultivo permanente, com uso intenso de fertilizantes, pode levar a um crescimento da produção e, conseqüentemente, a uma capacidade de carga artificialmente alta do agroecossistema.

Nas áreas da floresta amazônica, onde as temperaturas são altas ao longo do ano todo, as grandes chuvas podem facilmente lavar os solos descobertos, e a alta radiação solar pode levar à compactação do solo; as áreas desmatadas perdem sua capacidade de aglutinar nutrientes, devolvendo-os ao ciclo de nutrientes para destruir ervas daninhas e pestes e dar apoio aos ciclos locais de precipitação. Devido à rápida diminuição da produção agrícola nas áreas desmatadas depois de poucos anos de cultivo, as populações indígenas e os grupos locais de colonos assentados (caboclos e ribeirinhos) desenvolveram um modelo de uso agrícola intensivo da terra, conhecido como agricultura itinerante. Em uma situação de densidade populacional extremamente baixa e de grande disponibilidade de terras, esse tipo de sistema de cultivo, caracterizado pela baixa produtividade, por longos períodos de pousio e pelo trabalho manual no solo, é otimamente adaptado às condições existentes nas áreas de floresta tropical.

Do ponto de vista ecológico, a agricultura itinerante (com desmatamento por queimada em pequenos trechos dispersos na floresta primária, até então "estável") apresenta-se como a forma mais sustentável de uso agrícola (REICHHOLF, 1990; SIOLI, 1984d). Foram os projetos de colonização da Amazônia elaborados pelo governo que levaram à profunda destruição da estabilidade do ecossistema, por meio do aumento da densidade populacional e da conseqüente demanda de alimentos e assentamentos rurais.

5. Segundo a clássica visão ecológica tropical da grande estabilidade e da limitada resiliência da floresta tropical, a substituição em 
larga escala da floresta primária por campos e pastagens, no esquema dos programas de assentamento do governo, resultou no colapso do ecossistema por causa das infestações por ervas daninhas, da compactação do solo, da lavagem dos nutrientes e da falha nos ciclos de água locais (J ORDAN, 1985b; ODUM, 1991; SIOLI, 1984b). Inicialmente, essas falhas parecem ter-se confirmado nas áreas de assentamento mais antigas da Amazônia: a Zona Bragantina, no nordeste do Pará (CAMARGO, 1948b; SIOLI, 1973). Entretanto, as falhas dos planos de assentamento ao longo da Transamazônica e em Rondônia tiveram maior importância no debate internacional sobre as questões brasileiras (MORAN, 1981). Embora solos melhores do que os da Zona Bragantina tenham sido diagnosticados e embora as políticas de colonização tenham dado prioridade à integração de lavouras anuais e permanentes, as restrições ecológicas, juntamente com os grandes erros nos trabaIhos de planejamento e a ausência de oportunidades de marketing, levaram à diminuição drástica da produção, após os primeiros anos de cultivo, e a um subseqüente êxodo rural (MARTINE, 1990; MORAN, 1981; SMITH, 1982).

A pós o fracasso do programa de assentamento de pequenos agricultores, o governo estimulou e subsidiou a destinação de grandes áreas para atividades pecuárias, vistas pela Food and Agriculture Organization (FAO) e pela EMBRAPA-CPATU como um sistema de utilização da terra ecologicamente adaptado. Isso resultou na degradação das pastagens após o primeiro ciclo de 6-8 anos. Enquanto isso, metade do total das áreas de pastagem, cerca de 20 milhões de hectares, estava sendo degradado (SERRÃ O; HOMMA, 1993). Em vez da esperada ofensiva de exportação, a Amazônia representa hoje uma rede de importação de carne de gado.

O óbvio fracasso dos programas de desenvolvimento agrícola confirmou a visão do modelo ecológico tropical, segundo a qual a floresta tropical úmida da Amazônia é frágil e tem pouca capacidade de resiliência. Esse fato, aliado ao surgimento de "novas" ameaças globais devido ao aumento da produção de $\mathrm{CO}_{2}$, em razão da crescente destruição das florestas, levou organizações internacionais como o Banco Mundial e os programas nacionais de desenvolvimento nos países industrializados a modificar abruptamente sua percepção da Amazônia. Os planos dominantes anteriores foram deixados de lado e, devido à influência do ponto de vista ecológico tropical, foram substituídos pelos planos de proteção da floresta tropical. Isso resultou na predomi- 
nância de aspectos protecionistas, em detrimento das possibilidades de uso sustentável. No projeto piloto do G7 para a proteção da floresta amazônica (PP-G7), por exemplo, um elo entre a proteção florestal e o uso sustentável somente parece possível nos grupos indígenas ou nas reservas extrativistas e nos sistemas agroflorestais dos caboclos e ribeirinhos (WORLD BANK, 1992; WORLD BANK; BRAZIL, 1996).

Como a pecuária em larga escala deixou de atrair os empresários (devido à suspensão dos subsídios, a partir de 1990, e à falta de competitividade das empresas nos mercados fora da Amazônia), as dinâmicas de uso da terra por pequenos agricultores tornaram-se outra vez o centro das atenções nas questões de desmatamento.

Embora o uso da terra por pequenos agricultores seja responsável por apenas $30 \%$ da área desmatada, no final da década de 80 , esse "desmatamento silencioso" (HOMMA; WALKER, 1996) passou a ser visto como o principal problema. Se considerarmos 500.000 pequenos agricultores praticando a agricultura itinerante, com uma área cultivada média de 20 ha, como fez a EMBRAPA ${ }^{4}$, isso representaria uma área desmatada de 10 milhões de hectares (SERRÃO, 1995a).

A Unidade de Floresta Tropical do Banco Mundial e as lideranças ecológicas propoem rígidas restrições à agricultura itinerante, por meio de planos de uso da terra (zoneamento econômico-ecológico), e reduzem a construção de estradas (com a conseqüente valorização da terra), além de diminuírem as permissões de desmatamento, por empresa, de $50 \%$ para $20 \%$ da área (que foi relaxado pelo governo federal em julho de 1996) e os fundos de compensação (SCHNEIDER, 1995; WORLD BANK, 1992; WORLD BANK; BRAZIL, 1996).

Ao contrário dos caboclos e ribeirinhos, os pequenos agricultores são geralmente identificados como migrantes do Nordeste e do Sul do Brasil (colonos), os quais - assim se presume -, devido à falta de conhecimento das condições naturais locais, ao baixo preço das terras e à rápida diminuição da produção, abrem seu caminho através da floresta, como um verdadeiro rolo compressor de agricultores itinerantes (COY, 1988b; FEARNSIDE, 1985). Ao final do ciclo nas agrofronteiras, os grandes pecuaristas compram as terras dos pequenos agricultores. Entretanto, na visão do Banco Mundial, esses colonos estão, como quaisquer outros usuários extensivos de terras, simplesmente praticando "mineração de nutrientes" (extração não-sustentável dos nutrientes encontrados no solo), o que, do ponto de vista microeconômico e em razão do

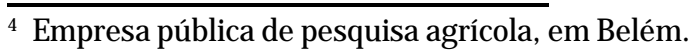


baixo preço das terras, poderia ser descrito até mesmo como um comportamento racional (SCHNEIDER, 1995; WORLD BANK, 1992).

0 diagnóstico de falta de sustentabilidade dos assentamentos de pequenos agricultores está de acordo com a clássica visão da ecologia tropical (J ORDAN, 1982, 1985; RICHARDS, 1973; UHL, 1983).

Modificações no clássico modelo ecológico tropical têm sido feitas ao longo dos anos, de forma relativamente despercebida pelas ciências políticas e sociais. Tais mudanças geralmente não questionam os postulados centrais do modelo teórico, mas corrigem algumas generalizações a respeito da floresta amazônica, bem como certas suposições sobre as conseqüências da substituição de espécies de florestas primárias por agroecossistemas mais pobres.

\section{Características das florestas amazônicas}

A caracterização das florestas pluvias amazônicas é resultado de estudos empíricos realizados em algumas localidades próximas a Belém (BLACK, 1950; CAIN et al., 1956; PIRES; DOBZHANSKY; BLACK et al., 1953) e especialmente em Manaus (FITTKAU, 1971; KLINGE, 1973b; KLINGE; BRÜNIG; FITTKAU, 1975; KLINGE et al., 1987 ), bem como em São Carlos, no Alto Rio Negro (HERRERA et al., 1978; J ORDAN, 1985b, 1989). A crença geral de que tais resultados poderiam ser aplicados a todos os diversos tipos de florestas da Amazônia começou a ser cada vez mais questionada, de um lado por estudos feitos em diferentes localidades amazônicas, particularmente na Amazônia oriental (Paragominas, Capitão Poço, Marabá, Peixe Boi, na Zona Bragantina) (DANTAS, 1989; GASH et al., 1996; NEPSTAD; UHL; SERRÃO, 1991; NEPSTAD et al., 1994, 1996; VIEIRA, 1996), e, de outro lado, pelos insights adquiridos graças aos estudos realizados em São Carlos (FRANCO; DEZZEO, 1994; J ORDAN, 1989) e Manaus (GASH et al., 1996). J ordan tornou bastante clara essa nova visão em seu livro de 1989, intitulado An Amazonian Rain Forest (Uma Floresta Amazônica), no qual estão listadas características que, em 1985, ainda eram consideradas como características gerais da floresta amazônica. As já conhecidas diferenças entre os diversos tipos de floresta amazônica, baseadas no clima variado e em fatores pedológicos, são aí colocadas em evidência.

De acordo com a visão ecológica tropical vigente, solos pobres em nutrientes, sem conteúdo mineral e com alto risco de lavagem (devido às taxas de precipitação permanentemente altas), eram indiscriminadamente ligados à predominância de um ciclo de nutrientes acima do solo, geralmente fechado em um conjunto florestal de três camadas, 
juntamente com raízes pouco profundas e fungos micorriza (KLINGE et al., 1975; RICHARDS, 1952, p. 219; SIOLI, 1984a). Num sentido estrito, essa visão baseia-se em uma floresta tropical perene, com clima tropical úmido (zonobioma equatorial com clima diurno) - em que a precipitação pluviométrica anual fica em torno de $2000 \mathrm{~mm}$, não caindo em nenhum mês abaixo de $100 \mathrm{~mm}$, e a precipitação excede a evapotranspiração não mais do que um mês por ano - e vegetação identificada como floresta perene das planícies (PIRES, 1978; RICHARDS, 1952; SCHIMPER, 1903; WALTER, 1973; WALTER; BRECKLE, 1984; WEISCHET, 1980; WEISCHET; CAVIEDES, 1993; WHITMORE, 1975, 1993). Alguns desvios dessa correlação estritamente implícita já haviam sido apontados por Sioli (1956), Pires, Dobzhansky e Black (1953) e pela Missão da FAO em Belém (GLERUM, 1965; HEINSDIJ K; BASTOS, 1963), no caso da Amazônia oriental, sem que tal fato tenha tido qualquer conseqüência para a extensa identificação de todas as florestas de terra firme com esse tipo de floresta perene.

Como Köppen (1931), Sioli (1956), tomando por base Schmidt (1947) e Soares (1953), subdividiu a região amazônica brasileira em três tipos básicos de zonas climáticas tropicais (Quadro 1). 0 traço mais comum foi uma taxa pluviométrica que ultrapassava a evaporação. Köppen e quase todos os autores que o citaram observaram uma correlação implícita entre o tipo climático e a cobertura vegetal. Bastos (1972, 1982) utilizou o mesmo método para produzir uma classificação quantitativa de toda a região amazônica, que ainda é comumente aceita e utilizada nos dias de hoje (DANTAS, 1989; FALESI, 1986, 1992; NASClMENTO; HOMMA, 1984). 


\begin{tabular}{|c|c|c|c|}
\hline $\begin{array}{c}\text { Tipo } \\
\text { Climático } \\
\end{array}$ & $\begin{array}{c}\text { Precipitação } \\
\text { anual (mm) }\end{array}$ & $\begin{array}{c}\text { Outras } \\
\text { características }\end{array}$ & \\
\hline Afi & $>2000$ & $\begin{array}{l}\text { precipitação mínima } \\
\text { mensal } 60 \mathrm{~mm}\end{array}$ & $\begin{array}{c}\text { = floresta tropícal equatorial } \\
\text { temperado (WALTER, 1973), } \\
\text { cobrindo } 17 \% \text { da região } \\
\text { amazônica brasileira, especialmente } \\
\text { a leste de Manaus, em Belém e em } \\
\text { parte dos deltas estuarinos. }\end{array}$ \\
\hline Ami & $>2000$ & $\begin{array}{l}2 \text { a } 3 \text { meses de } \\
\text { estação seca }\end{array}$ & $\begin{array}{l}\text { = floresta sazonal semidecídua } \\
\text { (WALTER, 1973), (WHITMORE, } \\
\text { 1975), cobrindo 41\% da região } \\
\text { amazônica brasileira, a maior parte } \\
\text { da terra firma o norte e ao sul do } \\
\text { Amazonas e o Nordeste do Parás. }\end{array}$ \\
\hline Awi & $<2000$ & $\begin{array}{l}5 \text { a } 6 \text { meses de } \\
\text { estação seca }\end{array}$ & $\begin{array}{c}\text { floresta decídua e savana, cobrindo } \\
46 \% \text { da região amazônica } \\
\text { brasileira, ao norte e especialmente } \\
\text { ao sul da zona Ami }{ }^{6}\end{array}$ \\
\hline
\end{tabular}

Quadro 1: Tipo climático, precipitação anual e características da vegetação.

Fonte: WALTER, 1973; WHITMORE, 1975.

Essa classificação corresponde muito precariamente aos mapas de vegetação da área do Amazonas brasileiro (514 milhões de hectares), produzidos com imagens do RADAM, a partir de 1974 (NASCIMENTO; HOMMA, 1984, p. 32).

\begin{tabular}{|c|l|}
\hline Área (mil. ha) & Classe \\
\hline 251 & Floresta ombrófila densa (49\%) \\
\hline 140 & Floresta ombrófila aberta (27\%) \\
\hline 123 & $\begin{array}{l}\text { Savana (17\%) } \\
\text { Campos naturais (7\%) }\end{array}$ \\
\hline
\end{tabular}

Quadro 2: Distribuição dos Tipos de Floresta.

Fonte: NASCIMENTO; HOMMA, 1984, p. 54.

Nascimento e Homma (1984) utilizaram unidades macroeconômicas em sua classificação para explicar especialmente esta correspondência limitada: a floresta densa cobre apenas 13\% na zona Awi, 29\% da área de terra na zona Afi e até $58 \%$ na zona Ami ao passo que a

${ }^{5}$ Porto Velho, Manaus, Santarém, Itaituba, Capitão Poço, Bragança e Paragominas.

${ }^{6}$ Altamira, Marabá, J i-Paraná, Conceição do Araguaia e Imperatriz.

198 
floresta aberta cobre $10 \%$ na Afi, $22 \%$ na Ami e até $68 \%$ na Awi (cálculos próprios, baseados em NASCIMENTO; HOMMA, 1984, p. 54). Esses números esclarecem o limitado apoio à correlação anteriormente proposta.

Os problemas de interpretação daí resultantes foram amplamente ignorados. Por isso, Clara Pandolfo ${ }^{7}$ foi capaz de identificar a floresta ombrófila em ambas as suas formas (fechada e aberta, $75 \%$ da área total) como uma floresta tropical perene (Hylea de Humboldt) na página 9 de sua publicação de 1978 e, a seguir, na página 18, subdividiu-a em sempre úmida (floresta ombrófila densa), de terra firme e floresta semi-úmida sazonal (floresta ombrófila aberta), da zona de cruzamento (PANDOLFO, 1978). A nova classificação da SUDAM e do IBGE (1988) apresenta a distribuição apresentada no quadro 3.

\begin{tabular}{|c|c|}
\hline Área (mil. ha) & Classe \\
\hline 200 & $\begin{array}{l}\text { Floresta ombrófila densa } \\
\text { (floresta tropical “real") (39\%) }\end{array}$ \\
\hline 100 & Floresta ombrófila aberta (19\%) \\
\hline 13 & Floresta estacional (3\%) \\
\hline 102 & $\begin{array}{l}\text { Savana (campos naturais) } \\
\text { Campos naturais (20\%) }\end{array}$ \\
\hline 80 & $\begin{array}{l}\text { Áreas ecologicamente sensíveis, sem forma } \\
\text { vegetal predominante }(16 \%)\end{array}$ \\
\hline 6 & Caatinga do Rio Negro (1\%) \\
\hline
\end{tabular}

Quadro 3: Distribuição dos tipos de floresta na Amazônia. Fonte: PANDOLFO, 1994, p. 157.

Em vez de terem sido esclarecidos, os paradoxos revelados pela missão da FAO e por Pires, no estudo da UNESCO de 1978, foram minimizados. Mesmo Cochrane e Sanchez (1982), em sua classificação de toda a bacia amazônica, baseada nas imagens do RADAM e em mapas de vegetação e pautada por critérios estritamente climáticos, tendem a aumentar os problemas de interpretação, ao definirem as formas vegetais para os tipos climáticos ${ }^{8}$ (Quadro 4).

7 Por longo tempo, gerente do Departamento de Recursos Naturais da SUDAM.

8 Ver também Nicholaides et al. (1983). 


\begin{tabular}{|c|l|}
\hline Área (mil. ha) & Classe \\
\hline 171 & Floresta tropical perene a oeste de Manaus e Belém (35\%) \\
\hline 274 & Floresta sazonal semiperene a leste de Manaus (57\%) \\
\hline 39 & Savana do Sul e do Norte \\
\hline
\end{tabular}

Quadro 4: Distribuição dos tipos de Floresta na Amazônia. Fonte: COCHRANE; SANCHEZ, 1982.

Apesar da homogeneidade de certos fatores climáticos (umidade acima de $80 \%$, temperatura anual média constantemente alta, cerca de $26^{\circ} \mathrm{C}$ ), existem claras diferenças na intensidade média da precipitação e especialmente na distribuição: na área de floresta equatorial perene e no estuário do Amazonas, a precipitação é bastante intensa (2500-3800 mm), com uma distribuição bastante regular e falta de períodos de seca; na floresta sazonal semiperene a leste de Manaus, as precipitações podem cair para $1700 \mathrm{~mm}$, especialmente na zona mais seca, que vai do Norte até o Sudeste de Santarém. Nessa área, embora as precipitações atinjam até $2300 \mathrm{~mm}$, é bastante significativo o distinto período de seca de 3 a 4 meses, durante os quais a precipitação mensal cai para abaixo de $60 \mathrm{~mm}$, a evapotranspiração excede drasticamente a precipitação e um déficit de água é esperado, com a conseqüente queda de folhas. Assim, de acordo com a classificação de Cochrane e Sanchez (1982), a floresta em torno de Manaus, com uma média de precipitação anual de $2100 \mathrm{~mm}$, porém com três meses secos, seria classificada como vegetação semiperene, com uma baixa diversidade de espécies e densidade de copas. Entretanto, o Instituto Max-Planck descreve a floresta nos arredores de Manaus como o protótipo da clássica floresta tropical, com biomassa e diversidade de espécies extremamente elevadas, além de um eficiente ciclo de nutrientes. Esse exemplo revela claramente os limites da abordagem dedutiva.

Enquanto a EMBRAPA continuava a justapor tipos de vegetação de clima de uma forma um tanto quanto ambígua, a busca da natureza da floresta tropical perene - e, portanto, também a busca de uma definição mais clara dos diferentes ecossistemas florestais na Amazônia estava sendo simulada por Cochrane e Sanchez (1982).

Várias classificações novas e reclassificações foram publicadas, nas quais Marabá e Altamira pertenciam, inicialmente, ao tipo Awi e apenas Capitão Poço pertencia ao tipo Ami (DANTAS, 1989); mais tarde, os três municípios foram classificados como do tipo Ami (DINIZ, 1986; SUDAM, 1984). Tomé-Açu, inicialmente um tipo Ami, mudou para o tipo Afi, tal como Belém, Moju-Capim e Marajó, apesar de Tomé Açu apresentar um período de seca de 5 meses, com uma ppt média anual de $2600 \mathrm{~mm}$ (SUBLER; UHL, 1990).

200 
Por razões climatológicas, Bastos et al. já haviam criticado a classificação de Köppen, de 1986, porém foi preciso que os resultados de estudos como os do grupo de pesquisa de Nepstad dessem um empurrão para chegar-se à solução do paradoxo das florestas perenes em áreas com períodos de seca (NEPSTAD et al., 1994). Com base no caso de Paragominas (com uma média de precipitação anual de $1750 \mathrm{~mm}$ e mensal abaixo de $50 \mathrm{~mm}$ durante os 5 meses de seca de julho a novembro), ficou provado o papel fundamental dos sistemas de raízes profundas, capazes de atingir reservas de água subterrâneas em profundidade, superando assim o déficit sazonal de água e sustentando o caráter perene da floresta em áreas a leste e ao sul na Amazônia. Com o auxílio de imagens de satélite, de mapas de vegetação e especialmente de escavações individuais de raízes, o novo tipo de "floresta de copa fechada" perene (floresta densa), caracterizado por uma dependência das fontes profundas de água subterrânea para superar a estação seca, passou a ser reconhecido como o responsável pela cobertura de $36 \%$ da área amazônica. Portanto, a floresta perene clássica, sem estação seca, cobre $39 \%$, as savanas e as florestas decíduas cobrem $41 \%$, e $11 \%$ são classificados como várzea (na sua maior parte, áreas desmatadas com vegetação perene secundária).

Os dados sobre evaporação de Cochrane e Sanchez (1982) precederam essa nova visão e a aceitação da importância dos sistemas de raízes profundas ${ }^{9}$, porém tiveram de superar os obstáculos da hipótese predominante de sistemas de raízes pouco profundas em florestas de copa fechada na Amazônia, válida, inicialmente, somente para o Alto Rio Negro e Manaus (J ORDAN, 1985a; KLINGE, 1973d; KLINGE; FITTKAU, 1972; PIRES; PRANCE, 1985; RICHARDS, 1973; SIOLI, 1984C). O fenômeno El Niño causou uma grande seca em 1992, contribuindo para a superação desses obstáculos. Nesse período, durante os 5,5 meses de estação seca em Paragominas, a precipitação total foi de apenas $95 \mathrm{~mm}$, em vez da média de $250 \mathrm{~mm}$, ou seja, 0,6 mm/dia, com uma taxa de evapotranspiração de $3,6 \mathrm{~mm}$ (floresta) e $3 \mathrm{~mm}$ (pastagens degradadas com vegetação secundária de 1-2 $\mathrm{m}$ de altura). Conseqüentemente, mais de $75 \%$ da água superficial disponível para as plantas originou-se de profundezas de solo de 2-8 m. Escavações de raízes realizadas primeiramente em Paragominas e depois em áreas com menores (Trombetas e Manaus) e maiores (Santana e Araguaia) precipitações sazonais revelaram profundidades de pelo menos $8 \mathrm{~m}$, mas também de até $18 \mathrm{~m}$. Investigações posteriores, dentro do projeto ABRACOS, reve-

9 Ver também WRIGHT et al., 1996; HODNETT et al., 1995. 
laram evidência adicional de sistemas de raízes profundas, especialmente em Manaus, onde as investigações iniciais de Klinge demonstraram a predominância de sistemas de raízes pouco profundas (ARAGUÁS-ARAGUÁS et al., 1995; HODNETT et al., 1995). Estudos simultâneos realizados no Suriname e no Sudeste asiático revelaram resultados semelhantes (BRUENIG, 1996, p. 26; POELS, 1987, 1994).

Não está claro se esses sistemas de raízes são característicos de florestas primárias de vegetação pioneira de crescimento rápido ou de florestas secundárias. Nepstad et al. (1996) chega a um resultado surpreendente: a profundidade das raízes (root length density) da vegetação secundária em pastagens degradadas é maior do que a da floresta primária na mesma área. A vegetação secundária de cinco anos, em Hgn - conforme Denich (1989) já suspeitava -, revela comprimentos semelhantes de raiz (DENICH; VLEK; FÖLSTER, 1995; WIESENMÜLLER; DENICH; VLEK, 1995). Dubois, Viana e Anderson (1996, p. 4 e p. 33) observam o papel importante dos sistemas de raízes profundas em plantas pioneiras para a absorção de água e nutrientes de camadas mais profundas de solo.

A inclusão desse papel desempenhado por sistemas de raízes profundas e a subseqüente rejeição do papel onipresente de raízes pouco profundas no ciclo eficiente de nutrientes na biomassa acima do solo tiveram consequêencias significativas para o entendimento de diversos ecossistemas florestais na Amazônia.

- Estudos recentes permitiram avaliar as hipóteses inicialmente aceitas de perdas extremamente altas de nutrientes por meio de altas taxas de ppt e especialmente pela remoção de vegetação primária (J ORDAN, 1985d). Estudos empíricos em ambos os tipos de floresta perene, mas também em florestas secundárias (Alto Rio Negro, Manaus, Capitão Poço, Marabá) revelam que as perdas de nutrientes são menores do que aquelas aceitas pelo modelo clássico, pelo menos nas áreas niveladas de terra firme (DANTAS, 1989; GASH et al., 1996; HÖLSCHER, 1995; J ORDAN, 1989; VIEIRA, 1996). Dependendo da profundidade da lixiviação, as perdas podem ser vistas, mas os nutrientes perdidos por esse motivo podem ser reciclados dentro do ecossistema pelas raízes profundas, contanto que o fluxo de água na superfície seja limitado. É preciso esclarecer ainda em que medida esse sistema mais complexo de planta-solo pode ser aplicado a áreas mais antigas, especialmente àquelas que utilizam o sistema de pousio, sem dependência de fontes de

202 
águas subterrâneas mais profundas. J ordan (1989) determinou empiricamente a perda de nutrientes pelo fluxo da água na superfície ${ }^{10}$ em vegetação secundária e especialmente nos sistemas de pousio, demonstrando que, além da grande atividade microbial, as raízes profundas podem desempenhar um papel significativo mesmo no Alto Rio Negro, pelo menos em oxissolos ${ }^{11}$, especialmente se isso for provado para os solos brancos, de areia, de estrutura semelhante aos de Sarawak (BRUENIG, 1996, p. 26). Os resultados de J ordan (1989) e de Vieira (1996) sobre a dinâmica do ciclo de nutrientes em vegetação secundária podem ser mais bem entendidos quando percebemos que se trata de dois ecossistemas florestais diferentes.

- Questiona-se também o elevado índice de reciclagem de nutrientes das florestas tropicais. 0 índice de reciclagem calculado por J ordan $(1982,1989)$ para a interação entre biomassa e solo, em São Carlos, atinge exatamente aquele das florestas de zonas temperadas. 0 índice de reciclagem de biomassa acima do solo, de Anderson e Swift (1983), calculado em 1,1 para Manaus, não é muito diferente dos índices das florestas decíduas da Bélgica. De acordo com a extensa análise feita por Anderson e Swift (1983), as taxas de retorno da maioria das florestas africanas e do Sudeste asiático (2,0-3,3) ficam significativamente acima dos índices de florestas decíduas em áreas temperadas $(0,4-1,3)$, porém muito pouco acima dos índices das florestas úmidas da América Latina e absolutamente nada acima dos índices das florestas tropicais montanhosas latino-americanas. A despeito da grande variedade de dados com os quais tiveram de trabalhar, Anderson e Swift foram capazes de provar que a suposição de uma dinâmica de alta decomposição das florestas tropicais deveria ser correlacionada a fatores de influência: 0 papel dos microorganismos, a qualidade do resíduo e as condições de clima e solo. Assim, a noção de Sanchez (1976) de que a biomassa e a dinâmica de decomposição das florestas tropicais são cinco vezes maiores do que as das florestas temperadas, apesar da semelhança no conteúdo de matéria orgânica do solo, além de ser superficial, não pode ser utilizada como característica empírica identificável para todas as florestas tropicais. Estudos mais recentes concordam com outro ponto de

${ }^{10}$ Menor, em comparação com medições anteriores.

${ }^{11}$ Primeira referência em Franco e Dezzeo (1994). 
vista (CUEVAS; MEDINA, 1988; J ORDAN, 1989; MEDINA; CUEVAS, 1996; TIESSEN; CUEVAS; CHACÓN, 1994): apesar da alta taxa de precipitação e de evaporação, as baixas taxas de decomposição de lixo $(0,5 \text { a } 0,7)^{12}$ ficam muito abaixo das de Manaus $(1,5)$ e, portanto, provavelmente ainda mais abaixo das taxas das florestas temperadas (J ORDAN, 1989, p. 22, p. 44 e p. 46). Além da constatação de que as perdas em razão do fluxo de água superficial são limitadas, somos levados a crer que as interaç̧ões entre vegetação e solo para o ciclo de nutrientes têm uma importância maior do que se pensava antes.

- Algumas das características do modelo ecológico tropical - como o papel central dos fungos micorriza e uma biomassa acima do solo extremamente elevada para um ciclo fechado de nutrientes acima do solo, os quais foram todos precipitadamente generalizados para todas as florestas tropicais -, parecem aplicar-se mais propriamente às áreas de podzol oligotrófico. Em pesquisa feita na literatura, Janos (1983) já indicava que os fungos micorriza têm papel importante apenas em áreas de solo de areia branca atípicos "azonais" (WALTER, 1973) na Amazônia ( $4 \%$ dos solos) e no Sudeste asiático. Isso significa que a tese do ciclo direto de nutrientes, proposta por Richards (1952) e depois apoiada por Went e Stark (1968), pode ser aplicada somente a $1 \%$ das florestas tropicais de planície do mundo ( $A$ NOS, 1983, p. 335).

- A correlação essencial entre diversidade extremamente elevada de espécies com um baixo número de incidência de indivíduos, solos pobres em nutrientes e estabilidade dos ecossistemas - apontados como características principais das florestas úmidas tropicais - não parece mais ser universalmente aplicável, como se pensava, de acordo com os resultados de recentes pesquisas. Isto é particularmente verdade no caso de solos extremamente arenosos, mas também para oxissolos do Alto Rio Negro, onde, devido a fatores oligotróficos e hidrotróficos, apenas umas poucas espécies com altos números de indivíduos parecem predominar em uma floresta sem camadas definidas (MORAN, 1993). Apesar da incidência extremamente elevada de chuvas, devido à estrutura do solo, as deficiências sazonais de água e o ressecamento da vegetação podem ocorrer e, nes-

${ }^{12}$ Entre outras razões, devido ao elevado conteúdo de lignina e ao baixo conteúdo de nutrientes, bem como devido a uma comunidade de decomposição pouco desenvolvida.

204 
ses períodos, é grande a probabilidade de incêndios naturais (NEPSTAD et al., 1996; UHL et al., 1990). Contrariando o ponto de vista mais estreito, os ecossistemas do Alto Rio Negro podem ser caracterizados por uma estabilidade limitada, mas com uma alta resiliência a choques e estresses. Uma correlação semelhante existe para áreas maiores a leste e ao sul da Amazônia (DANTAS, 1989).

Com base nos estudos feitos no Alto Rio Negro e em Manaus, podese afirmar que algumas das características do funcionamento da floresta úmida tropical clássica parecem não ser típicas de outras áreas de floresta na Amazônia, como o Nordeste do Pará.

É possível verificar a importância da contextualização do primeiro modelo clássico ecológico tropical, para o avanço da pesquisa, quando se observam os resultados preliminares sobre ilhas de florestas primárias, pastagens e florestas secundárias no Nordeste do Pará, a partir do Projeto SHIFT, bem como os resultados obtidos pelos grupos de pesquisa de Nepstad e Dantas (DANTAS, 1989; DENICH; VLEK; FÖLSTER, 1995; NEPSTAD; UHL; SERRÃO, 1991; NEPSTAD et al., 1994). Em vez de raízes pouco profundas, aqui predominam as raízes profundas, que não apenas permitem que as plantas superem os períodos de seca, mas também levam à reincorporação de nutrientes lixiviados de uma camada de solo profunda à biomassa. Além disso, a importância dos fungos micorriza e da fixação biológica do nitrogênio (FBN) parece ser menor do que a esperada. Whitmore (1975), J anos (1983) e Bruenig (1996) já haviam estabelecido esses resultados para o Sudeste da Ásia.

Não é possível fazer generalizações a partir desses resultados preliminares, pois importantes fatores climáticos bem como a seleção resultante de intensas intervenções antropogênicas no Nordeste do Pará ainda não foram levados em conta. Se tais processos dinâmicos de seleção ficarem provados - e tudo leva a crer que isso acontecerá - , então a resistência do ecossistema do Nordeste do Pará foi subestimada.

\section{Efeitos da substituição de florestas primárias ricas em espé- cies por agroecossistemas pobres em espécies}

As diferentes visões do funcionamento de ecossistemas florestais em relação aos fatores climáticos e pedológicos correspondem a uma mudança nos objetivos da pesquisa, ocorrida na década de 80: além dos estudos sobre as funções da floresta primária e sua capacidade de regeneração após intervenções antropogênicas, as pesquisas sobre as florestas secundárias, como parte integrante de um agroecossistema 
mais extenso na Amazônia, ganharam cada vez mais importância. Os primeiros estudos sobre a dinâmica de nutrientes e a acumulação de biomassa na agricultura itinerante foram feitos em São Carlos (J ORDAN, 1987b, 1989), porém seus resultados revelaram mais problemas de interpretação do que soluções. Os estudos que realmente ajudaram a desenvolver uma nova visão da resiliência dos ecossistemas em presença de constantes perturbações antropogênicas foram aqueles que se debruçaram sobre a capacidade de regeneração de pastagens degradadas: o de Buschbacher, Uhl e Serrão (1988), feito em Paragominas; o trabalho pioneiro sobre o papel da vegetação secundária na Zona Bragantina, há muito desmatada, realizado primeiramente por Cupertino, com o GTZ, depois com o Programa SHIFT; finalmente os estudos feitos por Dantas (1989) sobre Capitão Poço e por Vieira (1996) e Salomão, Nepstad e Vieira (1996).

Nesses estudos, destaca-se a Zona Bragantina, a mais antiga área de assentamento na Amazônia, iniciada há mais de cem anos. Tendo perdido a maior parte de sua floresta primária para o estabelecimento de terras agrícolas, a Zona Bragantina tem uma densidade populacional relativamente alta em termos de Amazônia, com mais de 30 habitantes $/ \mathrm{km}^{2}$ (40 habitantes $/ \mathrm{km}^{2}$ em Igarapé-Açu, em 1991) e possui um sistema de rodovias bem desenvolvido, o que permite o acesso à cidade de Belém.

A Zona Bragantina é, portanto, um laboratório ideal de livre alcance para o exame das principais hipóteses ecológicas tropicais sobre as conseqüências irreversíveis do desmatamento em larga escala ou a estabilidade ecológica dos sistemas de uso agrícola. Como ponto de partida, parece que estamos diante de um paradoxo insolúvel.

- Por um lado, do ponto de vista clássico ecológico tropical, a Zona Bragantina é descrita como uma paisagem fantasma, cujo colapso ecológico (infestação por ervas daninhas e degradação do solo) foi estabelecido nos anos 50 e 60 (EGLER, 1961; PENTEADO, 1967; SIOLI, 1973). A pesar das críticas iniciais sobre a descrição do estado de degradação da área, sem uma reconstrução histórica que pudesse explicar tal degradação (FALESI; BAENA; DUTRA, 1980), tanto o GTZ quanto posteriormente o Programa SHIFT presumiram a ocorrência de uma lenta degradação ecológica no sistema, baseada em uma perda gradual de qualidade de solo, com uma tendência para a diminuição da produção agrícola a longo prazo (BURGER; KITAMURA, 1987; DENICH, 1989).

- Por outro lado, estudos feitos na década de 80 revelaram que, pelo menos naquele momento, a área não se caracterizava por 
um estado elevado de degradação, conforme presumido por

Sioli e outros autores.

A solução para esse paradoxo foi encontrada em uma detalhada investigação sobre o papel da vegetação secundária, predominante na área e parte integrante do sistema de pousio praticado pelos agricultores locais. Esse tipo de vegetação foi obviamente capaz de assegurar a estabilidade ecológica naquela área. Assim, o projeto de pesquisa do GTZ/EMBRAPA identificou fatores socioeconômicos, como o aumento da densidade populacional e a escassez de terra, a diminuição dos períodos de pousio e o aumento do acesso aos mercados, como causa da diminuição de produtividade a longo prazo nesse sistema (BURGER; KITAMURA, 1987; DENICH, 1989). Os pesquisadores também indicaram a baixa diversidade de espécies do agroecossistema local, que é influenciada tanto pela base sociocultural dos colonos como pelo trabalho extensivo, que transmitiu aos colonos a imagem da monocultura como uma moderna técnica agrícola (BURGER; KITAMURA, 1987, p. 452). Isso tudo foi indiretamente confirmado pelos estudos sobre o sistema de pousio no Oeste da África, o qual demonstra um índice de diversidade muito maior (AMANOR, 1994; AY, 1996; STEINER, 1982).

Nos estudos feitos em Capitão Poço e Tomé-Açu, mais voltados para os aspectos socioeconômicos, e em Igarapé-Açu, sobre o cultivo permanente, foi analisada a importância da influência dos fatores socioeconômicos, porém sem relacioná-los de forma satisfatória às exigências da reprodução ecológica do sistema.

Os estudos sobre a importância da vegetação secundária para a relativa estabilidade do agroecossistema, a preservação das funções ecológicas básicas da floresta primária e as possíveis melhorias do sistema (melhores técnicas de cultivo) revelaram em detalhes as exigências de reprodução ecológica do sistema. A seguir, um resumo das conclusões do estudo feito pela EMBRAPA-CPATU e pelo GTZ (1986), da dissertação de Denich (1989), do subseqüente Projeto SHIFT, bem como dos estudos feitos por Vieira e Nepstad em Peixe-Boi.

\section{A importância da vegetação secundária para a relativa esta- bilidade dos agroecossistemas na zona Bragantina}

0 estudo do latossolo amarelo (chamado de oxisolos na classificação norte-americana) de Igarapé-Açu demonstrou que esse tipo de solo é tão antigo e pobre em nutrientes quanto a maioria dos solos amazônicos (sedimentos Barreira, do Plioceno e Plistoceno, com idade variando 
de 1 a 6 milhões de anos (DENICH, 1989, p. 19 e p. 31)). Exceção a essa regra são os sedimentos geologicamente mais antigos de calcário, areia e argila de origem marinha (formação Pirabas), que podem ser encontrados no leste da Zona Bragantina e em Igarapé-A çu. Esses solos estão localizados em parte sob os sedimentos Barreira e em parte na camada superficial do solo, apresentando teor de cálcio e pH aumentados até um nível acima da média para latossolos (SIOLI, 1951, 1960).

A produção anual de biomassa em Igarapé-Açu (20 t de biomassa acima do solo por hectare em 4,5 anos, conforme mensurado por Denich) é baixa, se comparada à de áreas de floresta secundária neotropical, embora o município seja considerada representativa da maioria das regiões da Amazônia ocidental que apresentam latossolo amarelo e podzólico amarelo, com relação a solos dominantes, condições de clima geral tropical (Ami, segundo Köppen, ou seja, uma estação seca defini$\mathrm{da}$, durante a qual os solos das camadas mais profundas permanecem úmidos graças a uma precipitação anual suficiente) e tipo de vegetação originalmente dominante (florestas tropicais sazonais). Denich (1989) explica essa baixa produção de biomassa pelo longo período de utilização agrícola na Zona Bragantina, que deve ter levado a um crescente empobrecimento dos solos já pobres em nutrientes, em conseqüência de sete a dez ciclos de cultivo-pousio, durante um período de 80 anos. Ele conclui que, aliada a uma redução de períodos de pousio de 10 para 5 ou 7 anos, devido à alta densidade populacional, deve ter havido uma diminuição da produtividade do sistema agrícola a longo prazo. Tal hipótese pode apoiar-se em afirmações de ecologistas como Camargo (1948), Egler (1961) e Sioli (1973), na interpretação dominante da desastrosa colonização da Zona Bragantina e em entrevistas contendo narrativas de pequenos proprietários de terra. Entretanto, sua validade ainda teria de ser confirmada pela reconstituição da história do povoamento, pois há informações que contradizem essa hipótese.

Os dados estatísticos do IBGE sobre o rendimento das colheitas mostram um crescimento considerável partindo de um nível baixo, no início da década de 70, para um nível mais alto, a partir do final dos anos 80 .

Vieira (1996, p. 52) comparou as qualidades de solo e concluiu que a qualidade de um solo de floresta secundária, com 10 anos, em uma área cultivada durante a década de 90 , é mais ou menos igual ou inferior à qualidade do solo em ilhas de floresta primária.

Segundo pesquisa própria, existem apenas vagas hipóteses sobre a redução de períodos de pousio, a longo prazo, que varia consideravelmente dentro dos municípios e não parece seguir uma tendência linear ao longo do tempo. Mesmo segundo o projeto Göttingen SHIFT, não 
ocorreu nenhuma diminuição constante de vegetação secundária entre 1984 e 1991. Em 1984, a parte de vegetação secundária na totalidade da área do município de Igarapé-Açu era de $73 \%$, diminuindo para $64 \%$ em 1988, mas aumentando novamente para 73\% até 1991. Dentro dessa faixa de 73\%, domina a vegetação secundária intermediária, com 5 a 10 anos. Em Peixe Boi, Vieira (1996, p. 25) chegou a resultados semelhantes, afirmando que a vegetação secundária com mais de 10 anos é dominante e está em crescimento.

Para a reconstituição histórica do desenvolvimento dos rendimentos, deveria ser levado em consideração um período maior, pois a tendência presumida por Denich tem maior possibilidade de ser confirmada para as primeiras décadas após o desmatamento primário do que para o período após a Segunda Guerra. Entretanto, é possível que, a partir dos anos 50 , os períodos de pousio e a intensidade de cultivo tenham variado bastante, de acordo com as diversas ondas de expansão de lavouras permanentes e pastagens. Provavelmente, o cultivo de lavouras anuais também foi influenciado pela competição entre as regiões Sul e Nordeste, após a construção das estradas nos anos 60.

A pesar da lenta degradação ecológica presumida por Denich, não é possível provar o colapso ecológico previsto por Sioli e suas conseqüências para a reprodução socioeconômica de agroecossistemas de pequenos proprietários, com base nos dados daquele autor para a década de 80. Isso se explica pela importância fundamental da vegetação secundária, freqüentemente negligenciada pelos pesquisadores de ecologia tropical, a qual foi dominante após o desmatamento primário e curtos períodos de cultivo, parecendo ser capaz de assegurar tanto os mecanismos ecológicos básicos da floresta primária, quanto a reprodução econômica dos sistemas de produção de pequenos proprietários, mesmo com um baixo nível de rendimento (DENICH; KANASHIRO, 1995).

Sob condições de baixo insumo externo (baixo uso de fertilizantes, predomínio do arado manual de solo por meio do trabalho familiar), a reprodução econômica dos sistemas de produção de pequenos proprietários depende, principalmente, de fatores ecológicos de reprodução e, em menor grau, de fatores socioeconômicos. Porém, os fatores ecológicos são altamente influenciados pelas decisões dos pequenos proprietários sobre a extensão do ciclo de lavoura, a escolha do cultivo e as formas de preparação do solo. Essa relação mútua entre condições de reprodução ecológicas e socioeconômicas é organizada pela decisão dos pequenos proprietários, dentro dos agroecossistemas. A economia de pousio dos pequenos proprietários consiste em dois subsistemas: 0 
ciclo de 2 anos de cultivo, baseado no milho, feijão e macaxeira, dominado pelo controle externo e antropogênico dos processos naturais de crescimento, e um período mais longo de pousio, em que o crescimento da vegetação secundária é um processo espontâneo e auto-organizado, com integração de arbustos e árvores (PRINZ, 1986).

A pesar da ausência de uma intervenção direta na sucessão natural, a vegetação secundária de 5 anos estudada por Denich e as vegetações secundárias de 5, 10 e 20 anos estudadas por Vieira não representam uma regeneração das florestas primárias, pois são mantidas constantemente no estágio inicial da sucessão secundária, devido à longa história de produção agrícola na região. Ao contrário do que foi constatado em Capitão Poço e São Carlos, onde o crescimento secundário foi estudado após um ou dois ciclos agrícolas depois do desmatamento primário, a composição de espécies da vegetação secundária em IgarapéAçu e Peixe Boi, após ciclos agrícolas de 7 a 10 anos, foi claramente influenciada pela utilização humana. Nesse caso, a composição de espécies é resultado de regeneração vegetativa por rebroto do toco, pois os estoques de sementes foram dizimados pelos freqüentes cultivos e queimadas do solo. Segundo Denich (1989), isso explica (juntamente com estoques reduzidos de fósforo e potássio) a ausência de espécies pioneiras típicas, como a Cecropia Palmata e muitas leguminosas predominantes em áreas de colonização mais recente, como Capitão Poço e Altamira (DANTAS, 1989; MORAN et al., 1996). As mudanças na composição de espécies de vegetação secundária devido à utilização humana em locais onde espécies típicas de floresta primária são raramente encontradas, segundo Denich (1989), ou ainda representam 50 a $60 \%$ de todas as espécies, segundo Vieira (1996, p. 40), não podem ser caracterizadas apenas como um processo de degradação ecológica. Isso pode ser justificado com dois resultados da pesquisa de Denich (1989).

Primeiramente, a predominância de regeneração vegetativa parece ser uma vantagem seletiva, por representar uma adaptação à escassez de nutrientes, pois os nutrientes estocados no sistema de raízes permitem uma rápida produção de brotos fortes e uma maior absorção de nutrientes por meio da distribuição espacial (DENICH, 1989, p. 182). A existência de raízes profundas é explicada pelos processos de seleção, contanto que já não existam na floresta primária, conforme presume Nepstad.

Em segundo lugar, Denich provou que, a despeito da longa história de atividade agrícola, o teor florístico da vegetação secundária é reduzido em comparação com o da floresta primária, mas ainda assim não se trata de uma comunidade pobre em espécies de plantas. Foram encontradas 137 espécies de árvores e arbustos e 46 de liana e sub-arbusto de 54

210 
famílias em 1,2 hectare. Fazendo uma comparação não muito detalhada, praticamente não haveria diferença entre o número total de espécies de floresta primária da Zona Bragantina nos anos 50 (BLACK, 1950; CAIN et al. , 1956; PIRES; DOBZHANSKY; BLACK, 1953) e o número total de espécies de vegetação secundária; a diferença estaria no tipo de espécies e no número de espécies de árvores, consideravelmente menor no segundo exemplo. Em comparação com as florestas primárias de Capitão Poço (DANTAS, 1989), com 188 espécies de árvores por hectare, e um remanescente de floresta primária, recentemente estudado em Peixe Boi, na Zona Bragantina (VIEIRA, 1996), com 268 espécies de árvores, os resultados de Denich indicam um número baixo, porém não insignificante, de espécies em vegetação secundária, dependendo do método de contagem (VIEIRA et al., 1996). Tal interpretação é corroborada pela contagem de espécies em uma floresta secundária de 5 anos, próxima de Peixe Boi (VIEIRA, 1996), que conta com pelo menos 62 espécies de árvores.

Em lugar de concentrarem-se na degradação ecológica e na redução de espécies, inevitavelmente ligadas à conversão de florestas primárias em áreas agrícolas, Denich e o projeto Göttingen SHIFT, bem como os grupos de pesquisa de Vieira e Nepstad, voltaram-se para a atuação positiva da vegetação secundária na estabilização dos agroecossistemas dos pequenos proprietários e na manutenção das funções ecológicas básicas, anteriormente garantidas pelas florestas primárias. As duas principais funções da vegetação de pousio para a manutenção da produtividade econômica das terras agrícolas consistem na acumulação de biomassa, cujos estoques de nutrientes são liberados para a lavoura através do fogo, e na contenção de plantas daninhas e pestes, que imigram para a área durante o ciclo de cultivo anterior (DENICH; KANASHIRO, 1995). Ambas as funções são igualmente fundamentais para os agroecossistemas extensivos, com lavouras anuais e crescimento secundário espontâneo. Com a redução do período de pousio, a importância do controle biológico de plantas daninhas é colocada em primeiro plano (VLEK; FÖLSTER, 1994, p. 4).

Devido ao caráter extensivo da economia de pousio, a reprodução econômica dos pequenos proprietários depende amplamente da relativa estabilidade dos ciclos de nutrientes e da manutenção de outros mecanismos ecológicos básicos. A pesar de toda a intervenção humana, estes últimos são auxiliados, em primeiro lugar, pela manutenção da biodiversidade - representada pelo potencial genético de espécies de árvores e arbustos e pelo habitat para animais; em segundo lugar, pela manutenção dos ciclos hidrológicos locais e regionais (DENICH, 1989; SALOMÃ O; NEPSTAD; VIEIRA, 1996; VIEIRA et al., 1996). 


\subsection{Ciclos hidrológicos}

Ao contrário do que se presume em quase todos os modelos climáticos, a conversão de grandes áreas de floresta primária em áreas agrícolas não está necessariamente ligada à drástica redução das taxas de evaporação e da precipitação pluviométrica em 25\% (NOBRE; SELLERS; SHUKLA, 1991; SHUKLA; NOBRE; SELLERS, 1990), nem ao correspondente aumento de temperatura (DALE et al., 1993; GASH et al., 1996). A pesquisa feita por Hölscher (1995) demonstra que um extensivo uso agrícola, com predomínio de vegetação florestal secundária como pousio, alcança taxas de evaporação próximas às médias das florestas amazônicas e indiscutivelmente mais altas do que a média das pastagens. Isso pode ser explicado pelo alto teor de folhas da vegetação florestal secundária de crescimento rápido (20 a 23\% em comparação com 2 a $4 \%$ da floresta primária), o que resulta em valores para o índice de área de folhagem e a interceptação de evaporação comparáveis aos da floresta primária. Portanto, cerca de $80 \%$ da radiação líquida é absorvida como calor latente para a evaporação de água, que está apenas um pouco abaixo dos valores encontrados em florestas primárias (cerca de $90 \%$ ) e exclui bastante o perigo de aumento de temperatura e de ressecamento do solo, em contraste com as pastagens. Além disso, a vegetação florestal secundária limita a enxurrada superficial, freqüentemente previsível. 0 alto índice de precipitação sobre a evaporação durante a estação chuvosa é, portanto, capaz de repor os estoques de água no solo, que atingem mais de $3 \mathrm{~m}$ de profundidade. Durante a estação seca, o superávit de evaporação pode ser compensado pela absorção de água dos estoques de água pelas raízes profundas das espécies florestais. 0 déficit de água é evitado e, ao mesmo tempo, os nutrientes das camadas mais profundas do solo ficam novamente disponíveis. A lixiviação seria, assim, bem menor do que o previsto pelo modelo de ecologia tropical (J ORDAN, $1985^{13}$ ). Mesmo que a validade geral desses valores ainda não esteja confirmada, está provado que a vegetação florestal secundária é fundamental para a manutenção do ciclo de água e para o ciclo de nutrientes a ele ligado.

É interessante observar que a pesquisa sobre lavouras permanentes, como pimenta-do-reino, oleaginosas e maracujá - que são comumente vistas como eficientes recicladores de água e nutrientes -, demonstrou que não são capazes de assegurar essas funções porque suas

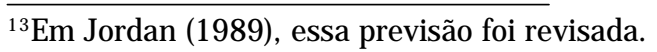

212 
raízes, muito menores, estão concentradas nas camadas mais altas do solo, de 0 a $1 \mathrm{~m}$ de profundidade, atingindo uma profundidade máxima de 2,5 m. Assim, em períodos de seca, poderia surgir estresse de água (water stress). As pastagens estudadas pelo projeto ABRACOS e por Nepstad mostram problemas similares em comparação às florestas primárias (GASH et al., 1996; NEPSTAD et al., 1996).

\subsection{Ciclos de nutrientes}

A incrível performance da vegetação florestal secundária na manutenção das funções ecológicas básicas, como o ciclo de água, permite uma interpretação diferente da atual representatividade dos impactos ambientais causados pela conversão de amplas áreas de floresta primária. Problemática, sem dúvida, é a estabilidade dos ciclos de nutrientes na interação entre plantas, microorganismos e solo, embora também haja desvios do modelo clássico de ecologia tropical. Conforme esse modelo, a maioria dos solos amazônicos é pobre em nutrientes, o que significa que eles circulam basicamente na biomassa acima do solo, dentro de um eficiente sistema de reciclagem. A penas ocorre pouco input de nutrientes por meio da precipitação a partir da atmosfera. Segundo esse modelo, além do cultivo rotativo extensivo ou pastagem, é impensável qualquer uso humano e sustentável da terra, com uma densidade populacional ou sistemas agroflorestais extremamente baixos. Os resultados da pesquisa em I garapé-Açu mostram que essa conclusão pode ter sido exagerada: em uma vegetação secundária de 5 anos, a maior parte dos escassos estoques de nutrientes pode estar localizada em camadas de solo de até $1 \mathrm{~m}$ de profundidade: $95 \% \mathrm{~N}, 81 \% \mathrm{Ca}, 75 \% \mathrm{Mg}$, $65 \%$ P, 56\% K (DENICH, 1989, p. 187).

O principal papel do acúmulo de nutrientes em biomassa de crescimento secundário está baseado, principalmente, na capacidade que as espécies florestais têm de tornar disponíveis para as lavouras nutrientes localizados em camadas mais profundas de solo. J untamente com a absorção por meio da precipitação, que excede a inundação de nutrientes por meio da lixiviação, a queimada de crescimento secundário cria um efeito fertilizante graças às cinzas ( 1,7 t por hectare) e aos resíduos de madeira (2,8 t por hectare), que permite o crescimento anual com baixo rendimento, sem fertilizantes adicionais (HÖLSCHER, 1995, p. 65).

O papel central das queimadas é tornar rapidamente disponíveis nutrientes em forma de cátions para o crescimento das plantas, posteriormente reforçado pelo rápido aumento de teor de pH e por um 
efetivo crescimento de CEC (FALESI, 1992; VIEIRA, 1996). Uma pequena quantidade de fertilizante pode aumentar, consideravelmente, a cobertura vegetal por meio de crescimento rápido. Outro importante efeito da queimada é a destruição de estoques de sementes de gramíneos persistentes, como a Imperata brasiliensis.

Como os métodos tradicionais de cultivo rotativo não perturbam o sistema de raízes, a vegetação florestal secundária pode reproduzir-se por meio do rebroto do toco, após a colheita.

Essas vantagens de curto prazo do cultivo rotativo têm sua contrapartida nas desvantagens ecológicas: alta perda de nutrientes pela atmosfera e redução de matéria orgânica. Os excedentes jogados na atmosfera, medidos por Hölscher (1995, p. 67), atingem 98\% C, 96\% N, $47 \%$ P, $76 \%$ S, 30\% Na, 48\% K, 35\% Ca e 40\% Mg, porém esses índices parecem ser extremamente altos em comparação com os apontados em outros estudos (DANTAS, 1989). Nutrientes com teores de cinza e remanescentes podres de madeira, no entanto, ainda são consideráveis. A redução de matéria orgânica - que, segundo Hölscher, atinge apenas uma porção insignificante e, de acordo com outros estudos, seria $4 \%$ menor do que em florestas primárias - leva a um reduzido efeito CEC (DENICH; VLEK; FÖLSTER, 1995; VIEIRA, 1996). Entretanto, isso deve ser interpretado como uma tendência contrária ao crescimento de CEC, por meio de aumentos nos teores de pH e de uma redução na concentração de Al.

Apesar da constatação de grandes perdas em consequê̂ncia das queimadas, os primeiros resultados dos projetos EMBRAPA/GTZe SHIFT mostram que os rendimentos da macaxeira, obtidos por meio do tradicional cultivo rotativo, são claramente maiores do que os rendimentos obtidos sem queimada, com a utilização de mulch (DENICH; VLEK; FÖLSTER, 1995, p. 63; EMBRAPA; GTZ, 1986). Os valores do comprimento das raízes estão, de modo semelhante, próximos entre si (DENICH; VLEK; FÖLSTER, 1995, p. 106).

A análise do conjunto de nutrientes para a totalidade do ciclo de pousio, segundo Hölscher, leva a um resultado negativo, principalmente devido ao ciclo de lavoura de dois anos, com grande perda de nutrientes na queimada e na colheita, que não pode ser compensada pela absorção de líquidos por meio da precipitação no período de pousio.

As perdas líquidas são drasticamente reduzidas e permanecem - no caso de baixo rendimento - apenas para K e levemente para P, no cálculo da análise do conjunto de nutrientes na forma de uma matriz pura input-output, do ponto de vista agroeconômico, e na contagem dos nutrientes acumulados na biomassa e disponibilizados para as plan- 
tas após a queimada ${ }^{14}$. 0 problema de uma análise do balanço de nutrientes é a ligação entre uma análise típica de agroecossistema com altas perdas e baixo rendimento por meio de baixa fertilização com pousio espontâneo com baixas perdas e inputs. Para este último, os mecanismos internos de reciclagem na interação entre as plantas, os microorganismos e o solo teriam de ser estudados de maneira mais detalhada; também deveriam ser mais bem estudadas a absorção de nutrientes pela exposição às intempéries e a fixação biológica do nitrogênio, bem como a reciclagem de nutrientes lixiviados por meio de raízes profundas (J ORDAN, 1989; LARCHER, 1994). Como a fixação biológica do nitrogênio é baixa, em razão da baixa significância dos fungos micorriza e das leguminosas florestais, o projeto SHIFT mantém a hipótese de um lento e progressivo empobrecimento dos solos, causado pelo equilíbrio negativo de nutrientes. Segundo o projeto SHIFT, a prova para tal hipótese é a mudança de solos devido à utilização agrícola (erosão laminar), que leva a uma realocação de partículas de argila (argila, matéria orgânica) em horizontes mais altos. Assim, solos que eram anteriormente classificados como latossolo amarelo (oxisol), são hoje classificados como podzólicos amarelos (ultisol) (DENICH; VLEK; FÖLSTER, 1995, p. 12). Além disso, mencionam-se rendimentos reduzidos, baseados em uma análise de dados de média estatística para o Pará, de 1984 e 1992. Se analisarmos todos os dados anuais desde 1974, tal argumento não mais se sustenta. 0 rendimento de todas as lavouras cresceu no início da década de 70, passando de um nível baixo para um nível consideravelmente alto, no início da década de $80^{15}$. Mesmo que a qualidade dos dados do IBGE possa ser questionada, outros autores, como Costa, utilizam esses dados para a análise de tendências gerais.

Do mesmo modo, Vieira (1996) chegou à conclusão de que a química do solo não é significativamente diferente quando se compara a vegetação secundária de 10 anos com áreas de floresta primária.

A tendência retratada grosso modo pelos dados do IBGE, que não sinaliza uma redução no rendimento, e os resultados obtidos por Vieira contrastam com as afirmações feitas por fazendeiros entrevistados e com o modelo do sistema de produtividade decrescente (DENICH, 1989). Os últimos trabalhos apresentados dentro do projeto SHIFT admitem que a estabilidade ecológica do sistema de rotação dos pequenos proprietários ainda não pode ser julgada devido à falta de dados, porém consideram sua instabilidade econômica como claramente provada.

${ }^{14}$ Cálculos próprios, com base em Hölscher (1995).

${ }^{15}$ Cálculos próprios, de acordo com fontes do IBGE. 
Essa questão central permanece ainda não muito clara, a despeito de alguns resultados das primeiras entrevistas do projeto socioeconômico SHIFT, que indicam uma clara redução do rendimento. Espera-se obter uma explicação satisfatória sobre o incerto desenvolvimento do rendimento por hectare por meio da reconstituição da história do assentamento em diferentes locais de Igarapé-Açu. Metodologicamente, presumimos que os dados dos fazendeiros sobre as reduções de rendimento ao longo de um período de 10 a 20 anos devem ser interpretados com cautela, quando dizem respeito à produtividade média de toda a fazenda. Temos ainda de levar em consideração a competição da produção barata vinda das regiões Sul e Nordeste, como no caso do arroz, do milho e mesmo da macaxeira, que causou uma clara queda nos preços dos mercados regionais, desde a construção das estradas ligando 0 Pará a essas regiões.

É necessário também analisar o impacto das flutuações de preço de mercado separadamente do desenvolvimento da produtividade por hectare e por trabalhador familiar, a fim de compreender melhor o papel das restrições ecológicas. Presume-se a existência de grande variação microecológica com condições gerais semelhantes de química de solo, que podem estar ligadas a uma história de utilização da terra espacialmente não uniforme (ver também DENICH; VLEK; FÖLSTER, 1995).

Em decorrência da falta de análises de tendências socioeconômicas de longo prazo relativas ao rendimento monetário e à produtividade física, os projetos EMBRAPA/GTZ e SHIFT relacionam a presumida queda da produtividade do sistema com fatores socioeconômicos (como a crescente pressão populacional e a integração de mercado), os quais levam a uma redução dos ciclos de pousio, e com a introdução de maquinário pesado e cultivos permanentes. Disso deduzem a necessidade de melhoramento do sistema de utilização da terra em condições de baixo input externo, especialmente por meio de intervenções nas formas espontâneas e auto-reguláveis de vegetação de pousio. 0 foco está no gerenciamento da matéria orgânica por meio, por um lado, do enriquecimento da capoeira com espécies florestais que acumulam e fixam biologicamente o nitrogênio, facilitando o encurtamento dos períodos de pousio, sem redução de produtividade, e, por outro, de modificações na preparação do solo, com a utilização de matéria orgânica não queimada, por meio de mulching, tanto manualmente quanto com o uso de uma máquina trituradora.

216 
Análise socioeconômica dos sistemas de uso de terra por pequenos produtores agrários na Amazônia oriental

\subsection{Lavouras permanentes e anuais}

As dificuldades para aumentar a sustentabilidade dos sistemas de utilização da terra pelos pequenos proprietários, com relação às lavouras anuais em sistemas agroecológicos, são resultado de uma avaliação pessimista do papel das lavouras permanentes e do cultivo mecânico do solo como alternativa para a intensificação agrária. Os resultados da pesquisa do projeto Göttingen SHIFT sobre os impactos negativos do cultivo mecânico do solo correspondem aos resultados das pesquisas feitas em São Carlos e Capitão Poço (DANTAS, 1989; UHL, 1982). Especialmente interessantes, embora afastados do estado da arte da discussão agroeconômica, são os resultados sobre a baixa sustentabilidade ecológica (e econômica) das lavouras permanentes em IgarapéAçu. Em desacordo com isso, pesquisadores e extensionistas da EMBRAPA e da EMATER e a escola de ecologia tropical, em geral, recomendam lavouras permanentes e sistemas agroflorestais como sistemas de utilização da terra mais adaptados aos climas úmidos e tropicais e aos solos pobres em nutrientes. Ainda assim, existem várias indicações sobre o modo como as lavouras permanentes devem ser integradas aos sistemas de produção agrícola (ALVIM, 1990; DUBOIS, 1996).

$O$ entendimento atual acerca da maior sustentabilidade ecológica das lavouras permanentes (seja em monoculturas, seja em culturas mistas) pode ser resumido a seguir. O cultivo de lavouras permanentes é a forma ideal de utilização da terra nos trópicos úmidos do Brasil, pois minimiza as intervenções ambientais locais e mantém o equilíbrio ecológico na região (ALVIM, 1989; HOMMA, WALKER, 1996). Do ponto de vista ecológico, lavouras permanentes e sistemas agroflorestais e de silvicultura estão mais próximos das florestas primárias, com relação à sua eficiência para proteger solos contra a erosão, a lixiviação e a compactação (ALVIM, 1989). Em comparação com as lavouras anuais de ciclo curto, as lavouras permanentes são mais eficientes na reciclagem dos nutrientes do solo e são, desse modo, mais adaptadas aos solos pobres em nutrientes. Sua alta capacidade de reciclagem baseia-se em sistemas de raízes profundas e extensas, uma alta devolução de nutrientes ao solo, devido à alta produção de dejetos, o aumento de matéria orgânica no solo e menor perda de nutrientes pela lixiviação do que a que ocorre nas lavouras anuais (SUBLER, 1993; TONIOLO; UHL, 1996). J untamente com o aumento de matéria orgânica e a atividade microbial, todos esses fatores aumentarão o CEC efetivo (SUBLER, 1993).

Porém, no caso dos freqüentemente citados sistemas agroflorestais de Tomé-Açu, a postulada superioridade das lavouras permanen- 
tes para manter a fertilidade do solo e o equilíbrio ecológico regional baseia-se na fertilização mineral, no intensivo cultivo manual e mecânico do solo e no uso de herbicidas (HOMMA et al., 1995; SUBLER; UHL, 1990).

São mencionados os riscos econômicos e os problemas fitossanitários que ocorrem regularmente após 6 a 8 anos, no caso da pimentado-reino e do cacau, e mesmo no caso de oleaginosas, porém tais riscos devem ser superados por meio de uma rápida transição para outras lavouras permanentes (ver KITAMURA et al., 1983).

Em contraposição às lavouras anuais insustentáveis, na forma de cultivos rotativos, devido aos reduzidos períodos de pousio, os sistemas de produção agrária baseados em lavouras permanentes, anuais ou não, parecem ser a nova proposta para um sistema de uso da terra ecológica, econômica e socialmente sustentável (SUBLER; UHL, 1990; WORLD BANK, 1992). Assim, a pecuária como forma ideal de uso da terra é substituída pelo modelo de lavouras permanentes, mais intensivo em capital, como o único meio de fixar a população rural.

Os fatores positivos das lavouras permanentes, aqui mencionados, correspondem ao que é afirmado pelos manuais de agricultura tropical, porém estes geralmente comparam as lavouras permanentes com a agricultura tropical permanente sem pousio (DOPPLER, 1991, p. 151; RUTHENBERG, 1980, p. 251; RUTHENBERG; ANDREAE, 1982). Essa comparação mostra que as lavouras permanentes possuem numerosas vantagens, distribuídas de maneira não uniforme entre os diferentes subgrupos de lavouras de campo, lavouras de arbusto e lavouras de árvores. Comparadas com a agricultura permanentemente banhada pelas chuvas, as lavouras permanentes estão mais bem equipadas para manter a capacidade de rendimento do solo por meio do sombreamento do solo, da contínua cobertura de solo leguminoso, da intensidade de cultivo relativamente menor, especialmente da capinagem, e do uso de fertilizantes financiados pelo maior rendimento monetário. No caso de alguns arbustos (Strauch) e lavouras de árvores, a influência no solo corresponde à da floresta, o que não ocorre nas lavouras de campo semipermanentes e nas lavouras mais intensivas de arbustos e árvores, como café, chá, cacau e pimenta-do-reino. Algumas lavouras permanentes, cujos produtos são fáceis de estocar e transportar, são capazes de oferecer alto retorno monetário por unidade de peso, o qual pode ser investido no uso de fertilizantes, pesticidas, herbicidas e na mecanização. Assim, a dependência da fertilidade natural do solo é superada e promove-se a fixação dos fazendeiros e a criação de plantações, o que, por sua vez, cria uma alta dependência de produtos e crédito de mercado. 
Muitas dessas características gerais são válidas apenas no estrito senso para campos intensivos em capital, lavouras de arbustos e de árvores, conforme preconizado por Ruthenberg. Os sistemas mistos de árvores, típicos dos sistemas agroflorestais, podem ser distinguidos daqueles últimos pelos seus ciclos mais longos de vegetação, pela necessidade muito menor de trabalho de capinagem, pelo maior grau de sombreamento de solo, pela reciclagem de nutrientes por meio de raízes mais profundas e por uma necessidade reduzida de fertilizantes (NATIONAL RESEARCH COUNCIL, 1993, p. 100; DUBOIS, 1996; DUBOIS; VIANA; ANDERSON, 1996). Evidentemente, a avaliação extremamente positiva das lavouras permanentes como forma de uso da terra nos trópicos úmidos (conforme defendido por Alvim) está baseada, em primeiro lugar, na categoria de capital intensivo e, em menor grau, nas lavouras de árvores, que são menos intensivas em capital. É também estranho que Alvim, ao enfatizar a alta capacidade de reciclagem de nutrientes, sempre compare isso com a agricultura permanente banhada pela chuva (como na Bahia) ou com as lavouras anuais da Amazônia, sem levar em consideração a capacidade bem maior de reciclagem da vegetação secundária. A condenação do cultivo rotativo como ineficiente e ecologicamente nocivo é resultado de uma tendência para favorecer estratégias de modernização intensivas em capital, por meio de plantações e de fazendas comerciais, típicas da agronomia dos anos 70. Em contraste com isso, os resultados do projeto Göttingen SHIFT mostram um quadro bastante diferente da sustentabilidade ecológica da pimenta-do-reino, das plantas oleaginosas e do maracujá. Devido ao aparecimento de fungos após 6 a 8 anos, que destroem as raízes, os autores ligados ao SHIFT questionam a sustentabilidade da pimenta-do-reino e caracterizam-na como lavoura semipermanente (DENICH; KANASHIRO, 1995). Devido à utilização intensiva mais alta, mesmo com a capinagem manual e o cultivo mecânico do solo bastante comum, a capacidade de regeneração vegetativa e generativa dessas áreas fica profundamente perturbada, de forma que a vegetação secundária que cresce após 0 abandono baseia-se apenas em umas poucas espécies, bastante degradadas, caracterizadas por pequenas ilhas de árvores e arbustos em áreas principalmente cobertas de capim (DENICH; VLEK; FÖLSTER, 1995, p. 21 e p. 29). No caso do preparo mecânico do solo, a sucessão pode ser caracterizada como regressiva (DENICH; VLEK; FÖLSTER, 1995, p. 22). Os campos abandonados de pimenta-do-reino, porém, mostraram possuir estoques de $\mathrm{P}$ e $\mathrm{K}$ até quatro vezes mais altos do que após o uso tradicional em uma biomassa irregularmente crescente, devido à fertilização com NPK, ao passo que N não foi crescentemente 
tomado (DENICH; VLEK; FÖLSTER, 1995, p. 31). Conforme demonstrado nas muitas entrevistas feitas durante a primeira fase do projeto socioeconômico SHIFT, em Igarapé-Açu, isso pode trazer vantagens para as lavouras anuais ou outras lavouras permanentes, em princípio. Porém, ainda assim, a reduzida produção de biomassa e, no caso das lavouras permanentes, a predominância de espécies daninhas e arbustos devem ser levadas em consideração, demandando um alto consumo de trabalho para preparar o solo para a próxima lavoura (DENICH; VLEK; FÖLSTER, 1995, p. 92 e p. 98).

A capacidade de regeneração da vegetação secundária fica especialmente perturbada após o cultivo mecânico do solo; de acordo com a visão acima apresentada, isso não seria problema, se a substituição por novas lavouras permanentes fosse altamente sustentável. Os resultados do projeto SHIFT questionam isso no caso da pimentado-reino, do maracujá e das plantas oleaginosas, particularmente no que se refere ao papel dos sistemas de raízes. 0 maracujá e a pimenta-do-reino possuem raízes muito mais curtas do que as de lavouras anuais $(0,3$ a 0,4 em vez de 1,3 a 2,7), que, por sua vez, são 20 a 30\% mais curtas do que as da vegetação secundária (DENICH; VLEK; FÖLSTER, 1995, p. 34). Mesmo as plantas oleaginosas somente atingem valores das lavouras anuais.

Até $90 \%$ desses reduzidos teores de raiz estão concentrados nas camadas mais superficiais do solo, de 1 a 2,5 m, respectivamente, ao passo que, no caso da lavoura anual tradicional, a massa de raiz em 1 a $2 \mathrm{~m}$ de profundidade representa apenas $30 \%$ da massa total de raiz.

No caso das lavouras permanentes, pode ocorrer estresse de água na estação seca e também quando a precipitação fica abaixo da média, em conseqüência de raízes mais rasas, enquanto as raízes mais profundas da vegetação secundária compensam os déficits de água e contribuem para o ciclo de nutrientes das camadas mais profundas do solo, de um modo ainda não muito claro.

Como os teores de massa de raiz mais baixos das diversas lavouras permanentes estão relacionados com um teor de carbono ainda mais baixo, o teor de dejeto orgânico de solo também é menor do que o das lavouras anuais. As lavouras permanentes provocam uma redução ainda mais drástica dos totais de estoque de carbono no solo do que as lavouras anuais. Isso reduz o CEC efetivo da pimenta-do-reino em um grau significativo (DENICH; VLEK; FÖLSTER, 1995, p. 22-23). 
Análise socioeconômica dos sistemas de uso de terra por pequenos produtores agrários na Amazônia oriental

\subsection{Resumo: os resultados mais importantes dos estudos re- centes}

A pesar de mais de cem anos de uso, o desmatamento em larga escala, nos últimos 50 anos, associado a uma densidade populacional relativamente alta, os sistemas de uso de pequenos agricultores, nos anos 80, provaram ser mais sustentáveis do ponto de vista ecológico e econômico do que se pensava nas décadas de 50 e 60 (EGLER, 1961; SIOLI, 1973).

Essa sustentabilidade depende, basicamente, do papel fundamental do período de pousio de cinco a dez anos entre dois anos de cultivo de lavoura anual. A vegetação secundária originada representa uma população de plantas menos rica em espécies, mas também não chega a ser pobre. Embora essa vegetação secundária seja mantida no estágio inicial da sucessão secundária e o fogo não represente um estágio regenerativo da floresta primária, é possível, graças à grande cobertura espacial (73\% da comunidade de Igarapé-Açu), à grande área de folhagem e às raízes profundas, que essa vegetação secundária desempenhe muitas das principais funções da floresta primária:

a) manter o ciclo hidrológico intacto por meio das altas taxas de evapotranspiração;

b) reduzir a lavagem da superfície por meio da cobertura de solo;

c) auxiliar a reintrodução de nutrientes lixiviados mais profundos na biomassa, pelo uso de sistemas de raízes profundas da espécies florestais;

d) contribuir para a diminuição da pressão de ervas daninhas, com árvores e arbustos pioneiros de crescimento rápido.

A pesar do uso intensivo de longo prazo, os estoques de nutrientes ainda não foram exauridos, em que pese a deficiência de alguns nutrientes, como fósforo $(\mathrm{P})$ e potássio $(\mathrm{K})$, indicando uma degradação paulatina do solo.

1. A hipótese daí resultante, segundo a qual a redução a longo prazo da produtividade do uso da terra é especialmente influenciada por fatores socioeconômicos, é explicada pela diminuição dos períodos de pousio, causada pelo aumento da densidade populacional, pela integração de mercado e pelas exigências monetárias.

2. A intensificação do cultivo por meio do uso de máquinas, de lavouras permanentes ou de elevados insumos externos não leva a um sistema de uso de terra mais sustentável. Na verdade, o dano ao sistema de raízes na vegetação florestal secundária, a infestação por ervas daninhas e a remoção de nutrientes aumentam drasticamente. 
3. É possível, portanto, uma manutenção ou uma melhoria do sistema de produtividade de uso em condições de baixo insumo externo por meio da melhoria do sistema de pousio extensivo (ou seja, melhora da vegetação secundária e utilização de nutrientes não queimados aí contidos e em espécies adaptadas). A implementação dessas propostas de melhoramento requer o conhecimento adequado 1) da aceitação dos pequenos agricultores de correr riscos e integrar inovações a seus sistemas, 2) das restrições a que eles estão sujeitos e das condições socioeconômicas nas quais operam, 3 ) de suas razões para usar ou não o sistema de pousio e 4) das barreiras locais específicas e socioeconômicas à adoção de tecnologias alternativas.

Esses resultados preliminares da pesquisa de campo do Projeto SHIFT negam a suposta sustentabilidade superior das lavouras permanentes em relação aos tradicionais sistemas itinerantes de cultivo. Embora os sistemas de lavoura permanente, com elevados insumos de fertilizantes, pesticidas e herbicidas, aliados ao cultivo mecânico, sejam possíveis na Zona Bragantina, nas atuais condições ecológicas e com elevados insumos de capital e trabalho, sua sustentabilidade a longo prazo, seja econômica, seja ecológica, é bastante duvidosa. 0 fato de que é exatamente isso que pregam os atuais planos de modernização agrícola para a região é inquestionavelmente problemático.

Os resultados acima mencionados não se aplicam, necessariamente, a agroecossistemas tão artificiais quanto os de Tomé-Açu, com seu alto nível de biodiversidade, suas lavouras permanentes e anuais, sua produção animal e seu sistema agroflorestal bem natural (ANDERSON, 1990a; DUBOIS, 1990). Entretanto, é possível chegar a uma conclusão: lavouras permanentes não são a solução propriamente dita para os problemas ecológicos e econômicos da Zona Bragantina. Suas características associadas, ambientalmente corretas, podem restringir-se a árvores frutíferas plantadas extensivamente ou a sistemas permanentemente fertilizados e artificiais, com elevados insumos externos, como em Tomé-Açu.

\section{Lacunas socioeconômicas atuais no estudo shift da zona Bra- gantina}

Ao contrário dos conceitos de intensificação agrícola da EMBRAPA, o Projeto SHIFT concentra-se na estabilidade ecológica e econômica dos sistemas de uso da terra por pequenos agricultores, no Nordeste do Pará.

Estudos recentes revelaram problemas relacionados à implementação das melhorias propostas para o sistema, os quais devem ser abordados por estudos socioeconômicos.

222 
O Projeto Göttinger SHIFT já formulou uma lista de desigualdades e reivindicações que precisam ser solucionadas pelo atual projeto e especialmente pelo projeto socioeconômico (VLEK; FÖLSTER, 1994). Esperase uma modificação do sistema de uso de terra pela agricultura itinerante de queimadas dos pequenos agricultores, para manter, e até mesmo meIhorar, a produção primária e a biodiversidade da Amazônia oriental, a fim de garantir um suprimento básico de alimentos à população local e, ao mesmo tempo, diminuir as pressões de uso na floresta amazônica (DENICH; KANASHIRO, 1995; VLEK; FÖLSTER, 1994, p. 4-5).

Essa mistura de proteção florestal, manutenção de funções ecológicas básicas por meio do crescimento de vegetação secundária e meIhora das condições socioeconômicas de reprodução das famílias de pequenos agricultores, com o objetivo de intensificar estratégias, requer maior investigação em condições controladas de campo, no que diz respeito 1) às conseqüências do método de preparação de solo sem queimada e de mulching ou incorporação de material de plantas florestais, 2) à melhoria da vegetação de pousio, 3) à melhoria das espécies e 4) à estabilidade ecológica de lavouras mistas agroflorestais ou áreas abandonadas de lavoura permanente ou pastagens. Além disso, pacotes de tecnologia de uso alternativo da terra devem ser desenvolvidos, com base nos resultados dos testes, e testados com relação à viabilidade e à aceitação por parte das famílias de pequenos agricultores. Presume-se que os pequenos agricultores sejam reticentes quanto à incorporação de novas tecnologias a seus sistemas familiares, em parte devido ao fracasso da adoção dos sistemas de lavoura com aléias; entretanto, tecnologias de fácil implementação, que prometem retorno rápido, são imediatamente aceitas, embora haja o perigo de que todos os agricultores imitem o pioneiro e, por conseguinte, de que ocorra a queda dos lucros em potencial.

Os pequenos agricultores, sem um plano de uso de terra contínuo e de longo prazo, tendem a transformar campos itinerantes de lavouras de baixa produção anual em lavouras permanentes, destinadas a fazer lucro (pimenta, maracujá, frutas cítricas), tendo em vista benefícios econômicos de curto prazo (preços elevados, mas momentâneos, de mercado, ou crédito agrícola subvencionado pelo FNO Especial). Em razão da instabilidade de preços do mercado (frutas cítricas) e de problemas fitossanitários (pimenta), essas áreas são logo abandonadas; porém, devido às ervas daninhas, o restabelecimento de vegetação secundária é mais lento.

Outra falha no aproveitamento de oportunidades pelos pequenos agricultores é a dependência cada vez mais elevada do auxílio mecânico e do uso de agrotóxicos, o que aumenta os lucros e a produção a curto 
prazo, mas, a médio prazo, resulta na quebra do sistema de pousio e em custos elevados, tornando-se ecológica e economicamente insustentável.

A solução proposta pelo Projeto SHIFT é a análise dos atuais sistemas de uso da terra dos pequenos agricultores e a melhoria dos sistemas de pousio com lavouras anuais e pousio de floresta ou arbustos. A sustentabilidade ecológica e econômica desses últimos sistemas é presumida. As lavouras permanentes, que são plantadas por muitos pequenos agricultores por motivos econômicos e que freqüentemente desempenham um importante papel no seu sistema de produção, são removidas - de acordo com o princípio das melhorias propostas - , por causa de seu efeito ecológico negativo na regeneração do crescimento secundário. Portanto, a possível combinação das lavouras anuais com o cultivo de diversas lavouras permanentes, com variadas exigências de nutrientes e fertilizantes e um limitado risco de perdas por doença (como em Tomé-Açu e Capitão Poço), não é vista pelos pequenos agricultores como uma etapa plausível da intensificação. Essa opção é categoricamente eliminada das meIhorias do sistema, apesar de ser a principal tendência no Nordeste do Pará, no momento (COSTA, 1995; KITAMURA et al., 1983).

A crítica, muitas vezes esclarecedora, da falta de sustentabilidade ecológica e econômica de certas lavouras permanentes, com preparação mecânica do solo e uso de agrotóxicos, foi, inicialmente, confirmada sem hesitação, ao comparar-se diferentes municípios da Zona Bragantina (como Tomé-Açu e Capitão Poço).

\subsection{Produção de subsistência e de mercado ${ }^{16}$}

Estudos recentes e entrevistas pessoais pintam um quadro diferente (COSTA, 1994; KITAMURA et al., 1983; PENTEADO, 1967; SANTANA 1990, 1995):

1. O grau de comercialização das "lavouras de subsistência" nos anos 50 e 60 foi, com exceção da mandioca, provavelmente bem maior do que o de hoje; a diminuição da produção de longo prazo dos empreendimentos individuais, apontada pelos agricultores entrevistados (enquanto as produções do IBGE permaneciam constantes), bem como a competição com produtos importados mais baratos vindos do Sul e das agrofronteiras foram os fatores que transformaram as lavouras anuais em "lavouras de subsistência".

${ }^{16}$ Para uma descrição da situação comumente encontrada em Igarapé-Açu, favor consultar Denich $(1989$, p. 5) e Denich, Vlek e Fölster (1995, p. 2).

224 
2. Ainda mais importante para a orientação para o mercado e provavelmente também para a degradação do solo nas décadas de 50 a 70, foi o papel essencial das lavouras voltadas para o lucro, como a pimenta, a malva e o algodão, produtos utilizados como matéria-prima pela indústria (FLOHRSCHÜTZ, 1983; PENTEADO, 1967; SAWYER, 1979a, 1979b).

3. Com relação à orientação dos pequenos agricultores para o mercado, em Igarapé-Açu, os dados coletados em 1989 por Santana (1990) e registros pessoais revelam uma imagem bastante clara: a parte da produção para venda no mercado, originada do valor da produção bruta dos pequenos agricultores, representa $60 \%$; para os pequenos agricultores entrevistados, com uma média de 15,5 a 4,2 hectares de terra cultivada, atinge até mesmo $90 \%{ }^{17}$. Geralmente, a fatia das lavouras anuais destinada ao mercado excedia a fatia consumida pela família. Também é possível perceber o papel desempenhado pelas lavouras permanentes (murici, pimenta, urucu, cupuaçu, laranja) e pelas lavouras voltadas para o lucro (algodão e maracujá) na obtenção de receitas monetárias, mesmo para agricultores com áreas de terra bem pequenas.

De acordo com a atual terminologia agroecológica, a maioria dos empreendimentos entrevistados em 1989 deveria ser classificada como empreendimentos orientados para o mercado (cf. DOPPLER, 1991). Porém, uma vez que, mesmo nas famílias mais ricas, as necessidades de subsistência alimentar são amplamente satisfeitas pela produção, a análise dos cálculos de economia familiar deveria ser um cálculo misto envolvendo segurança alimentar, redução de risco e elevada orientação para o mercado.

4. 0 sistema de uso de terra dos pequenos agricultores, tanto no passado quanto atualmente, não pode ser reduzido ao cultivo de lavouras anuais em um sistema de pousio. Na verdade, está provado que se trata de um sistema muito mais complexo, em que são importantes as pequenas áreas de lavouras permanentes, os pomares domésticos com árvores frutíferas e a longamente ignorada criação de animais, a qual é alimentada pela quase totalidade da produção de milho (COSTA, 1995; KITAMURA et al., 1983).

5. A dinâmica da economia familiar dos pequenos agricultores pode, assim, ser adequadamente entendida quando levamos em conta a longa existência de uma produção orientada para o mercado, constantemente pressionada pela necessidade de assegurar fontes de alimento, tornar variada a produtividade física - ao longo do tempo e en-

${ }^{17}$ Cálculos próprios, com base em Santana (1990, p. 38). 
tre os empreendimentos, em função de preços mutáveis de mercado - e garantir disponibilidade de terras adequadas ao cultivo, trabalho familiar e outras fontes de renda.

A tarefa da análise socioeconômica seria obter uma imagem mais realista das disparidades tendenciais e cíclicas entre a produção de subsistência e a orientada para o mercado, por meio de uma reconstituição histórica das tendências de desenvolvimento acima mencionadas.

$\mathrm{Na}$ verdade, esses resultados demonstram que, apesar do grande peso das receitas monetárias oriundas de lavouras permanentes, a área coberta por elas permanece relativamente baixa, se incluirmos as áreas de pousio no cálculo das áreas utilizadas para lavouras anuais (o que raramente é levado em conta pelos agroeconomistas). Constata-se que os sistemas de pousio desempenharam um papel importante, especialmente em empreendimentos mais bem-sucedidos, apesar da assumida preferência pelas lavouras permanentes. Assim, devido à grande quantidade de terras disponíveis, melhorou muito a relação entre campos de pousio e campos cultivados com lavouras anuais. Com um ano e meio de cultivo, todos os empreendimentos incluem um período de pousio de cinco a seis anos. 0 índice de rotatividade R de 19 ("Rico") para 25 ("Pobre") fica claramente acima do valor atual para agricultura itinerante (abaixo de 10), porém abaixo dos valores para agricultura de pousio (acima de 33) (cf. DOPPLER, 1991; RUTHENBERG, 1980).

A dificuldade reside em definir isso claramente para o típico sistema de uso da terra, tanto em I garapé-Açu como no Nordeste do Pará. As expressões "agricultura itinerante", "cultivo cruzado floresta-campo", "agroecossistema com pousio de floresta", "pousio de arbustos" e mais recentemente (com referência a BRINKMANN, 1924, p. 959) "cultivo de alocação de campo", frequentemente empregadas de forma intercambiável pelo projeto Göttinger-SHIFT e pela EMBRAPACPATU, salientam a complexidade do problema, sem esclarecê-lo de maneira satisfatória. Na perspectiva ecológica, a diferença entre sistemas de uso de terra pode ter, sem dúvida, importância secundária, mas, na perspectiva socioeconômica, parece ser necessário separar esses conceitos. Ambas as formas de agricultura itinerante - com ou sem mudança de localização - são utilizadas de forma indistinta e freqüentemente pejorativa para contrapor a agricultura itinerante às lavouras permanentes, ecológica e economicamente mais estáveis, enquanto os sistemas de uso de terra por pequenos agricultores são frequentemente mencionados sem a indicação do papel preponderante do pousio na análise.

226 
A importância socioeconômica da queimada, como método de fertilização de baixo custo, também não está muito clara. Na perspectiva ecológica, as elevadas perdas pela volatilização de nutrientes seriam vistas como os principais limites da sustentabilidade ecológica e econômica. Na perspectiva da análise socioeconômica e nos cálculos econômicos de uma economia familiar, o trade off entre as óbvias vantagens econômicas, porém de curto prazo, da queimada e a esperada diminuição da produção de médio e longo prazo e o aumento da demanda por fertilizantes, dada a limitada disponibilidade de terras e solos pobres em nutrientes. Com os resultados preliminares do projeto socioeconômico Berlim, podemos chegar à seguinte hipótese: pequenas economias familiares, devido ao seu complexo sistema de objetivos, não visam de maneira nenhuma a maximização de receitas monetárias a curto prazo; ao contrário, dão alta prioridade à segurança alimentar de médio prazo e à redução de riscos, bem como à melhoria da situação econômica familiar, a longo prazo, por meio do acúmulo de recursos tangíveis. Entretanto, atualmente, pouco pode ser dito sobre o valor dos cálculos econômicos, freqüentemente contrários, nos processos de decisão dos pequenos agricultores, uma vez que apenas poucos estudos tratam esse assunto de forma sistemática (ct. COSTA, 1994, 1992a, 1992b; DOPPLER, 1991; ELLIS, 1993; KITAMURA et al., 1983; ALMEIDA, 1992; SANTANA, 1990). Uma outra explicação para o processo de decisão dos pequenos agricultores seria crucial, especialmente para o projeto Göttinger SHIFT, que concebeu a introdução prática de melhoria do sistema, a qual estaria provavelmente ligada a uma mudança de curto para médio prazo nas vantagens ecológicas.

0 esclarecimento das estruturas confusas dos cálculos socioeconômicos dos pequenos agricultores poderia, então, definir uma zona de convergência, feita de sustentabilidade ecológica e de segurança da existência econômica, bem como de melhoria dos padrões de vida (também em DOPPLER, 1991). A ligação entre sistemas ecológicos e sociais e o processo de decisão da economia familiar poderia ser discutida em um nível menos agregado.

\section{Situação da análise socioeconômica dos sistemas de uso da terra na Amazônia e no norte do Pará}

Os esclarecimentos sobre o significado dos fatores socioeconômicos que influenciam a dinâmica dos sistemas de produção de pequenos agricultores e seu potencial de inovação são relevantes apenas em uma abordagem teórico-metodológica que liga as perspectivas agroecológi- 
ca, socioeconômica e agrossociológica, de tal forma que a lógica interna da análise é respeitada e é também assegurada a troca de idéias.

Os problemas metodológicos dos estudos anteriores resultaram, acima de tudo, da situação insatisfatória das atuais abordagens predominantes para definir os pequenos agricultores amazônicos. Examinaremos isso no texto a seguir, de forma a tornar as exigências teóricometodológicas mais compreensíveis.

Na fase de modernização agrícola forçada, na década de 70 , os estudos socioeconômicos concentravam-se na análise da expansão da indústria de grande porte e da presença temporária de assentamentos de subsistência nas fronteiras agrícolas (agrofronteiras) (COY, 1988b; FOWERAKER, 1981; HÉBETTE; ACEVEDO, 1979a; VELHO, 1976). Com base nas experiências feitas no Sul do Brasil (particularmente no Paraná), os pesquisadores partiram de um ciclo de fronteira típico, que começa em uma área seletivamente cortada. Na fase inicial desse ciclo, pequenos agricultores (detentores de títulos precários de terra) asseguram o fornecimento de produtos alimentícios de baixo preço aos centros urbanos, além de garantirem sua subsistência com agricultura itinerante (HÉBETTE; ACEVEDO, 1979b). Na segunda fase, o sucesso inicial é gradualmente corroído pelo papel explorador do grande capital, pela precariedade dos títulos de terra, pela insuficiência da infra-estrutura, pelo papel privilegiado dos grandes empreendimentos nas políticas agrícolas e pela diminuição da produção por causa dos solos pobres em nutrientes. Ao final do ciclo de fronteira, a maioria dos colonos é deslocada ou marginalizada pelas grandes fazendas de gado e pelas plantações agrícolas permanentes. Na melhor das hipóteses, a terra é transformada em pasto, aumenta de valor e é vendida antes do deslocamento da família (REYNAL et al., 1996). Desenvolve-se, então, um sistema de propriedade de terra polarizado, e a maioria dos colonos vai para a próxima fronteira ou para a cidade (COY, 1988a; MARTINE, 1990, para Rondônia; HÉBETTE; ACEVEDO, 1979b, para o Pará).

Durante muito tempo, esse "ciclo de vida da fronteira", estudado mais especificamente em Rondônia, no Mato Grosso e no Sul do Pará, definiu a análise socioeconômica dos pequenos agricultores na Amazônia (COY, 1988b). O ciclo foi aceito como uma tendência geral de toda a Amazônia, tanto na versão político-econômica (FOWERAKER, 1981) como na variante neoclássica de extração não-sustentável dos nutrientes encontrados no solo (nutrient mining) (ALMEIDA, 1992; ALMEIDA et al., 1992; SCHNEIDER, 1995), devido à contínua construção de rodovias. Essa visão dos pequenos agricultores na Amazônia, juntamente com uma visão indistinta do cultivo nômade itinerante, mantém-se nos 
documentos e análises oficiais até os dias de hoje (SERRÃO; HOMMA, 1993; WORLD BANK, 1992).

A presença de instituições do governo central modifica o ciclo de fronteira. Dependendo dos planos governamentais de colonização, são observados no início do ciclo tanto pequenos agricultores como grandes fazendas de gado. É por essa razão que Coy (1988) parte de um ciclo mais curto de 15 anos.

\subsection{Transamazônica}

Os planos de colonização agrícola para a Transamazônica providenciaram títulos de terras e, a partir de 1976, proporcionaram fácil acesso ao crédito para lavouras permanentes (cacau, pimenta, café). Entre 1981 e 1991, houve a consolidação de pequenos agricultores em empreendimentos de médio porte (100-200 hectares) (ALMEIDA et al., 1992; CASTELLANET; SIMÕES; CELESTINO FILHO, 1994).

\subsection{Marabá}

Grandes pecuaristas e uma massa faminta de migrantes formaram a população inicial de Marabá, o que ocasionou competitivas disputas por terras e o desenvolvimento de um movimento social politicamente ativo e bem organizado, que defendia os direitos de terras dos migrantes (HÉBETTE, 1996). 0 trabalho CAT/LASAT permitiu a estabilização econômica das economias de pequenos agricultores familiares, por meio do acúmulo "patrimonial" de terra e gado (REYNAL et al., 1996). Mais uma vez, é difícil determinar se isso representou a fase final do ciclo de fronteira, em razão a) da existência de elevadas, porém variáveis, porções de floresta primária (20-80\%), b) da grande importância da produção pecuária na região e do aumento de pequenas fazendas familiares, desde que 0 programa de colonização do Instituto Nacional de Colonização e Reforma Agrária (INCRA) passou a vigorar, na década de 90, e c) da crença de que grandes fazendas de gado não eram lucrativas.

\subsection{Paragominas}

Com a construção da rodovia Belém-Brasília, a área foi aberta aos grandes empreendimentos pecuários do Sul do país, os quais se estabeleceram ao longo da estrada, ganhando o monopólio sobre a terra e deslocando tanto os antigos residentes ribeirinhos, como os novos colonos. Nesse caso, a exaustão do primeiro ciclo de pastagens 
levou ao aumento da extração de madeira e ao surgimento de grandes concentrações de serrarias em todo o Pará e no Amazonas. 0 acúmulo patrimonial de gado e terra era possível apenas até certo ponto e de forma bastante limitada (FIGUEIREDO, 1994), devido ao absoluto domínio dos grandes empreendimentos pecuários. Em resposta a isso, nas divisas das grandes fazendas, os ribeirinhos do Rio Capim organizaram um grande movimento comunitário, a fim de assegurar os seus direitos tradicionais de uso de terra, e os colonos de Uraim, perto de Paragominas, diversificaram sua produção agrícola. Em Uraim, a diversificação foi auxiliada pela garantia dos títulos de terras, a partir de 1980, bem como pela ajuda técnica dinâmica e cooperativa da igreja italiana (1973-1977) (INHETVIN, 1991). Inicialmente concentrado em lavouras anuais e no sistema produtivo de queimada, o sistema de produção foi diversificado para abranger lavouras permanentes (especialmente pimenta), verduras e pequenas produções leiteiras (COSTA, 1995; NITSCH, 1992; TONIOLO; UHL, 1996). A queda dos preços da pimenta e os problemas fitossanitários levaram esse modelo a uma crise que, de acordo com Toniolo e Uhl (1996), resultou na venda de mais da metade das propriedades de pequenos agricultores a proprietários urbanos, os quais continuaram a diversificar a produção de forma intensiva em capital. Toniolo e Uhl (1996) caracterizam essa forma de intensificação como uma estratégia de consolidação ecológica e economicamente sustentável para os pequenos agricultores. 0 fato de essa venda de terras ter dado origem a novos movimentos migratórios, tanto nas cidades como nas novas fronteiras, não é levado em consideração.

Esses casos apresentam-se como exceções à tendência generalizada à polarização da propriedade de terras e como prova da precariedade das propriedades familiares. Não se sabe ainda as razões pelas quais, pelo menos em sua forma clássica, o ciclo de fronteira foi apenas parcialmente eficiente, mesmo nas áreas clássicas de antigos assentamentos, como a Zona Bragantina, ou em antigas fronteiras no Nordeste do Pará (como Tomé-Açu, Uraim e Paragominas, Irituia e Capitão Poço).

\subsection{Capitão Poço}

O estudo pioneiro de Sawyer (1979a) e a subseqüente análise dos sistemas de produção, feita por Costa (1995), do Núcleo de Altos Estudos Amazônicos (NAEA) da Universidade Federal do Pará (UFPA), e pela cooperação GTZ/EMBRAPA (KITAMURA et al., 1983), indicaram o papel pri-

230 
mordial desempenhado por um sistema de produção notavelmente complexo na cidade de Capitão Poço, cujo crescimento foi particularmente dinâmico. Entretanto, esses estudos tratam a lavoura de pousio de forma apenas superficial. Ao contrário de outros casos estudados, Capitão Poço não apresenta nenhuma das fases do ciclo de fronteira; em vez disso, parece ser uma continuação da colonização agrícola caracterizada por pequenos agricultores, existente na Zona Bragantina. Desde o final da década de 40, bem antes da construção da rodovia Belém-Brasília, agricultores vindos do Ceará, mas também da Zona Bragantina, iniciaram a derrubada da floresta primária, plantando lavouras anuais e requerendo títulos de terra. A penas após a conexão inter-regional, ocorrida na década de 60, foi possível a comercialização de arroz e farinha de mandioca e o cultivo da malva, como matéria-prima industrial. Embora a maioria dos agricultores possuísse títulos de terras por volta de 1970 (especialmente de 20 e 50 hectares), Sawyer presumiu que o ciclo de fronteira era válido para Capitão Poço e predisse um aumento no deslocamento dos colonos devido às plantações de pimenta e às fazendas de gado. Essa afirmação seria, segundo ele, confirmada pela dependência dos colonos da natural fertilidade do solo, que é ciclicamente restaurado no sistema de pousio, porém Sawyer previu uma diminuição tendencial, devido aos períodos mais curtos de pousio, causados pela crescente pressão populacional ou pela monopolização de terras. A subseqüente exaustão do solo seria compensada apenas pelo aumento de insumos fertilizantes ou pelas lavouras permanentes, as quais, de acordo com Sawyer, excediam a capacidade econômica dos agricultores. Surpreendentemente, o autor apega-se à sua visão pessimista, apesar de indicar em seu texto o caráter inovador dos pequenos agricultores, sua crescente dependência do sistema de aviamento, sua flexível integração ao mercado e o grande sucesso de sua ampliada reprodução socioeconômica. Devido ao alto custo do sistema de Capitão Poço, obviamente Sawyer é capaz de imaginar apenas a integração parcial das lavouras permanentes ao sistema de produção dos pequenos agricultores, por meio de empreendimentos capitalistas. Por outro lado, seu interessante estudo permanece preso ao estereótipo da limitada eficiência e capacidade de acumulação das propriedades familiares (SAWYER, 1979a).

Alguns anos mais tarde, pesquisadores da EMBRAPA (KITAMURA et al., 1983) diagnosticaram uma crescente diversificação dos sistemas de produção agrícola: das 85 fazendas pesquisadas em 1982, apenas $37 \%$ produziam primariamente lavouras anuais (produtos alimentícios, além de algodão e malva, como matéria-prima para a indústria) (Sistema I); 32\% produziam lavouras anuais e pimenta (Sistema II); 24\% 
produziam lavouras anuais, pimenta e haviam começado com produção animal (Sistema III). Os 7\% restantes produziam lavouras anuais e animais (Sistema IV). A produção para consumo pessoal (mandioca, arroz, milho e feijão) estava entre 13 e $32 \%$ do valor bruto da produção. A produção para o mercado (68-87\% do valor bruto da produção) era principalmente de pimenta, farinha de mandioca e lavouras comerciais anuais (algodão e malva). Lavouras alimentícias (mandioca, misturada com arroz, milho e feijão) eram importantes para garantir uma dieta diversificada (o milho servia principalmente para alimentar pequenos animais) e, no caso da mandioca, para produzir excedentes de mercado. A fatia de mandioca no total da produção para o mercado (normalmente acima de 50\%) é o dobro da produção de pimenta para os Sistemas I, II e IV; a mesma coisa acontece com a pimenta no Sistema III (39\%). De acordo com os trabalhos da EMBRAPA, cuja linha é predominantemente socioeconômica, mandioca, arroz e milho mostram equilíbrio negativo, mas o feijão e a malva mostram um equilíbrio positivo, quando se leva em conta o trabalho familiar a um custo de oportunidade (salário mínimo regional) (BARBOSA, 1981). Uma vez que os agricultores plantarão essas lavouras de qualquer maneira, apesar das perdas, os autores atacam a lógica e a estrutura de custos das economias familiares, que são diferentes das empresas capitalistas: segundo os autores, o elevado retorno da mandioca garante ao trabalho familiar a longo prazo uma compensação muito maior do que o algodão, a malva e possivelmente também a pimenta (KITAMURA et al., 1983, p. 13 e p. 32). No caso desta última, a explicação está na limitada área no cultivo da pimenta (geralmente $1 / 4$ de hectare muito perto das hortas familiares), que requer grande investimento inicial e custos de manutenção; a cultura é, portanto, apenas estendida passo a passo, financiada pela receita da mandioca, do algodão e da malva. O cenário geral representa um desvio da visão estereotipada dos pequenos agricultores e ilustra os constantes processos de aprendizagem e a evolução desses agricultores, em resposta a influências externas (KITAMURA et al., 1983, p. 24). A expansão dos resultados das lavouras permanentes resulta em um processo de aprendizagem "fazendo e aprendendo", baseado na interpretação subjetiva dos riscos de flutuação de mercado e na disponibilidade de recursos financeiros pessoais, bem como na suficiente força do trabalho familiar. Alguns produtores suplementam essas economias com a compra de gado para produção leiteira e também com o acúmulo de rebanhos como "poupanças vivas".

Apesar da crescente diversificação do sistema de produção, todos ainda acreditam no papel fundamental da farinha de mandioca, facil-

232 
mente estocável, como fonte principal de alimento e produto mais importante do mercado. Assim, os autores da EMBRAPA vêem a mandioca como um produto produzido pela maioria dos agricultores em uma área mais ou menos constante de cultivo, independentemente dos preços de mercado e da produtividade (KITAMURA et al., 1983, p. 22). A mandioca, portanto, não apenas serve para garantir o alimento a longo prazo, mas também é a base para investimentos em arriscadas lavouras comerciais anuais e permanentes, cuja área de cultivo flutua enormemente em relação aos preços de mercado (KITAMURA et al., 1983, p.10).

A diversidade no sistema de produção é restrita a uma grande variedade de lavouras anuais para consumo e também para beneficiamento industrial. Isso implica o continuado predomínio dos sistemas tradicionais de queimada (Quadro 5).

\begin{tabular}{|c|c|c|c|c|}
\hline $\begin{array}{c}\text { Área } \\
\text { total (ha) }\end{array}$ & $\begin{array}{c}\text { \% de } \\
\text { empreendimentos }\end{array}$ & $\begin{array}{c}\text { Tamanho } \\
\text { médio }\end{array}$ & \% cultivada & $\begin{array}{c}\text { Área } \\
\text { cultivada (ha) }\end{array}$ \\
\hline$<10$ & 21 & 2,8 & 97 & 2,68 \\
\hline $10-50$ & 32 & 27 & 20 & 5,15 \\
\hline$>50$ & 47 & 85 & 12.7 & 10,83 \\
\hline
\end{tabular}

Quadro 5: Capitão Poço - Distribuição de Área.

Fonte: KITAMURA, 1983.

Os empreendimentos menores, que normalmente não possuem títulos de terra e, devido aos limitados recursos de terras, também não possuem terras para pousio, são, aparentemente, produtores de verduras ou parte de um grupo maior de agricultores sem terra ou com poucas terras, que funcionam como reserva de mão-de-obra para suprir a falta temporária de trabalhadores agrícolas nos sistemas de produção com relativamente pouca mão- de-obra familiar (Sistemas I e III).

Os autores da EMBRAPA enfatizam o caráter dinâmico do mercado de trabalho local: especialmente produtores que produzem apenas alimentos e matéria-prima industrial (Sistema I com menor mão-de-obra familiar de 2,8) empregam trabalhadores assalariados para fazer até aproximadamente $12 \%$ do trabalho. Isso é financiado com a renda de empregos temporários fora do empreendimento familiar ${ }^{18}$, porque as diversas combinações de alimentos e matéria-prima para a indústria podem exigir uma carga temporária maior do que a capacidade de mãode-obra familiar. Isso também se aplica aos Sistemas II e IV, nos quais a

${ }^{18}$ Cálculos próprios, baseados em Kitamura et al. (1983, p. 28). 
lavoura permanente de pimenta representa uma fatia menor do valor de venda, devido à drástica queda de preços no mercado mundial e à diminuição ainda maior dos preços no mercado interno.

Enquanto o estudo feito pela EMBRAPA limita a crescente diversificação da produção às lavouras anuais em sistemas de pousio, apesar da crescente importância da pimenta, a pesquisa de Costa (1994), anos mais tarde, em 100 empreendimentos, revela a predominância na composição do valor bruto de produção (incluindo o consumo pessoal) das lavouras permanentes e, em menor escala, das lavouras anuais, para todos os empreendimentos.

\begin{tabular}{|l|c|c|}
\hline \multicolumn{1}{|c|}{ Categoria } & $\begin{array}{c}\text { \% do valor } \\
\text { bruto }\end{array}$ & $\begin{array}{c}\text { \% do valor } \\
\text { líquido }\end{array}$ \\
\hline Lavoura permanente $^{19}$ & 45 & 44 \\
\hline Lavoura anual $^{20}$ & 17,8 & 21,8 \\
\hline Pequena criação de animais & 20 & 25 \\
\hline Gado & 16.7 & 10 \\
\hline
\end{tabular}

Quadro 6: Capitão Poço - Distribuição do Valor Bruto e Líquido. Fonte: COSTA, 1997.

A modificação da estrutura de produção torna-se mais clara por meio da comparação com produtos centrais: enquanto, em 1982, a farinha de mandioca representava $>50 \%$ do valor de venda, predominando em todos os sistemas de produção e valendo no total o dobro da única lavoura permanente - a pimenta -, exatamente o oposto é observado em 1993 (Quadro 7)

${ }^{18}$ Cálculos próprios, baseados em Kitamura et al. (1983, p. 28).

${ }^{19} 20 \%$ de pimenta, $11 \%$ de maracujá, $7,7 \%$ de laranja, $1,9 \%$ de coco.

${ }^{20} 10 \%$ de mandioca, $7,3 \%$ de feijão e $1,3 \%$ de algodão.

234 
Análise socioeconômica dos sistemas de uso de terra por pequenos produtores agrários na Amazônia oriental

\begin{tabular}{|l|c|c|c|}
\hline Categoria & Lavoura & \% do valor bruto & \% do valor líquido \\
\hline Lavouras permanentes & pimenta & 20 & 22,6 \\
\cline { 2 - 4 } & maracujá & 11 & 4,2 \\
\cline { 2 - 4 } & laranja & 7.7 & 1,2 \\
\hline \multirow{4}{*}{ Lavouras anuais } & mandioca & 10.1 & 12,5 \\
\cline { 2 - 4 } & feijão & 7,3 & 4,2 \\
\cline { 2 - 4 } & algodão & 1,3 & 1,7 \\
\cline { 2 - 4 } & milho & 1,1 & 1,4 \\
\cline { 2 - 4 } & arroz & $>1$ & $>1$ \\
\cline { 2 - 4 } & malva & $>1$ & $>1$ \\
\hline Animais & gado & 14,8 & 9 \\
\cline { 2 - 4 } & porcos & 2,1 & 2,6 \\
\cline { 2 - 4 } & galinhas & 17 & 21,2 \\
\hline
\end{tabular}

Quadro 7: Capitão Poço - Distribuição do valor entre os produtores agrários.

Fonte: COSTA, 1997.

Em 1993, tanto o valor bruto como o líquido das lavouras permanentes (pimenta e maracujá) eram claramente superiores aos das lavouras anuais. A criação animal também era maior em 1993 do que em 1982. A comparação entre os valores bruto e líquido indica altos custos de produção para a laranja, o feijão e o gado e custos comparativamente menores para a mandioca e as galinhas e, surpreendentemente, também para a pimenta e o maracujá.

A fatia do valor líquido utilizada para consumo pessoal, que em 1982 ficava entre 20\% (Sistema III) e 48\% (Sistema I), em 1993 atingia uma média de $32 \%$ para as lavouras anuais ( $24 \%$ de mandioca, $42 \%$ de feijão, $80 \%$ de arroz e $83,4 \%$ de milho), de $90 \%$ para a pequena produção animal, de $19 \%$ para o gado e de $13,6 \%$ para as lavouras permanentes. Comparada à visão geral do papel central desempenhado pelas lavouras anuais, a classificação do consumo pessoal revelou o papel predominante de pequenos animais (61\%) e uma participação substancialmente menor das lavouras anuais (19\%), das lavouras permanentes (16\%) e do gado (5,6\%). A alta proporção de lavouras permanentes aponta para um alto grau de diversificação, especialmente em árvores e arbustos frutíferos que, como o açaí, a manga, o caju e a jaca, são primordialmente consumidos dentro da família e, juntamente com pequenos animais, fornecem a proteína necessária a seus membros. 
Um grau maior de diversidade nos principais componentes dos sistemas de produção é observado na classificação do sistema de produção de 1993, com relação à classificação de 1982. Enquanto as lavouras anuais, especialmente a mandioca, predominavam em todos os grupos de produção em 1982, por volta de 1993 observava-se o seguinte padrão: as lavouras anuais predominavam no Sistema I, enquanto em todos os demais predominavam as lavouras permanentes.

\begin{tabular}{|c|c|c|c|}
\hline Sistema & $\begin{array}{c}\text { \% de todos os } \\
\text { empreendimentos }\end{array}$ & $\begin{array}{c}\text { Área média } \\
\text { total (ha) }\end{array}$ & $\begin{array}{c}\text { Área média } \\
\text { cultivada (ha) }\end{array}$ \\
\hline $\mathrm{I}$ & 9 & 13,2 & lavoura anual 2,4 \\
\hline $\mathrm{II*}$ & 36 & 36,6 & $\begin{array}{c}\text { lavoura anual 2,4 } \\
\text { lavoura permanente 4,5 }\end{array}$ \\
\hline $\mathrm{III}^{*}$ & 53 & 67 & $\begin{array}{c}\text { lavoura anual 5,3 } \\
\text { lavoura permanente 6,3 } \\
\text { pastagem: 15,5 }\end{array}$ \\
\hline
\end{tabular}

Quadro 8: Classificação dos Sstemas de Podução de 1993.

Fonte: COSTA, 1997b.

* Sistemas com diferenças estatísticas entre 1982 e 1993.

Os valores da produção bruta das lavouras anuais ficavam entre 17 e $18 \%$ (somente a mandioca entre 9,4 e $10,4 \%$ ) e os das lavouras permanentes entre $47,7 \%$ (III) e $58,5 \%$ (II); para o gado,os valores correspondiam a $23,3 \%$ (III) e, para os pequenos animais, ficavam entre $18,5 \%$ (III) e $23,7 \%$ (II).

Com base na comparação desses três sistemas de produção, Costa tentou identificar os fatores que podem ter levado ao aumento da eficiência dos pequenos empreendimentos. Ele utiliza a renda líquida por trabaIhador familiar, obtida dentro do empreendimento familiar, como o principal parâmetro de comparação, desprezando (especialmente por razões metodológicas) os rendimentos obtidos fora das atividades agrícolas (ou seja, salários, pensões e serviços prestados). Ele justifica essa opção pela dificuldade em registrar de forma adequada esses rendimentos líquidos com duas outras pesquisas: $78 \%$ dos entrevistados admitiram participar de atividades não agrícolas e $86 \%$ das famílias não recebiam rendimentos fora daquele obtido dentro do empreendimento familiar (rendimento agrícola). Em sua avaliação desse mesmo material, Grossmann (1995) indicou que até $61 \%$ das famílias admitiram receber rendimentos de atividades não agrícolas: $30 \%$ dos gerentes dos empreendimentos obtinham receitas não agrícolas, em $25 \%$ dos casos a esposa ou os filhos trabalhavam fora da propriedade e $13 \%$ das famílias recebiam pensões. 0 pres-

236 
suposto de Costa segundo o qual, à la Tschajanow, os rendimentos não agrícolas dos empreendimentos familiares típicos não causam grande impacto na dinâmica de seu desenvolvimento é da maior importância. Essa elaboração restritiva do modelo de propriedade familiar contrasta com os gargalos mundiais nos ciclos familiares, mas também na Amazônia. Com efeito, diversos estudos empíricos confirmam a grande importância dos rendimentos agrícolas e não agrícolas, oriundos de fora da propriedade, para superar as cíclicas crises econômicas (especialmente nas lavouras anuais) e a subutilização da mão-de-obra familiar fora de temporada. No estudo feito pela EMBRAPA em 1982, a renda extrapropriedade no Sistema I (com uma média de mão- de-obra familiar de 2,8\%) representava $55 \%$ do valor do rendimento da propriedade ${ }^{21}$.

Apesar de ter desprezado o rendimento extrapropriedade, Costa concentrou-se no rendimento anual da propriedade por trabalhador familiar, o que tem a vantagem de poder esclarecer a dinâmica das propriedades familiares em relação aos preços de mercado, à produtividade física e à utilização da mão-de-obra familiar. Costa observou um aumento para o dobro do valor líquido de produção nos Sistemas I, II e III e um aumento de certa forma menos análogo do rendimento por trabaIhador familiar. Os valores por ele encontrados correspondem, aproximadamente, aos valores apontados no estudo feito pela EMBRAPA embora num nível claramente mais baixo. Os custos de produção, em 1993, também mostraram um nítido aumento nos sistemas ${ }^{22}$.

\begin{tabular}{|c|c|c|c|c|c|c|}
\hline \multirow[t]{2}{*}{ Sistema } & \multicolumn{2}{|c|}{$\begin{array}{c}\text { Custos de } \\
\text { produção \%* }\end{array}$} & \multicolumn{2}{|c|}{$\begin{array}{l}\text { Fatia de consumo } \\
\text { pessoal do valor bruto } \\
\text { de produção** }\end{array}$} & \multicolumn{2}{|c|}{$\begin{array}{c}\text { Dimensão } \\
\text { da mão-de-obra } \\
\text { familiar*** }\end{array}$} \\
\hline & 1982 & 1993 & 1982 & 1993 & 1982 & 1993 \\
\hline 1 & 32,5 & 2,3 & 32,3 & 55,2 & 2,86 & 4,6 \\
\hline II & 21,5 & 23,6 & 23 & 36,7 & 4,06 & 6,24 \\
\hline III & 32 & 36,1 & 12,5 & 32 & 3,3 & 5,86 \\
\hline & & & & Média: & 3.4 & 5,57 \\
\hline
\end{tabular}

Quadro 9: Capitão Poço - Comparação de Indicadores de 1982 e 1993.

Fonte: KITAMURA, 1983; COSTA, 1997.

*Tendência irregular nos sistemas em 1983; tendência de crescimento em 1993.

** Nítida tendência de redução em ambos os estudos.

*** Crescimento do Sistema I ao II em ambos os estudos e pequena redução do II para o III.

${ }^{21}$ Cálculos próprios.

${ }^{22}$ Cálculos próprios, baseados em Kitamura et al. (1983) e em Costa (1996). 
A quantidade maior de mão-de-obra familiar em 1993, que é explicada pelo ciclo familiar, também explica a atenção de Costa para a carga de trabalho nos diversificados Sistemas II e III. Isso também permite o esclarecimento da fatia extremamente pequena dos custos de produção no valor bruto de produção do Sistema I (2,3\%), internamente menos diversificado: um terço $(4,6)$ da mão-de-obra familiar com um potencial de 1380 dias de trabalho (em 300 dias por ano) foi utilizado efetivamente no empreendimento, o que eliminou a necessidade de trabalhadores de fora da família. Embora a fatia de produção para consumo pessoal (55\%) seja alta, a grande quantidade de mão-de-obra não utilizada dentro do empreendimento sugere que pelo menos uma parte da mão-de-obra familiar está envolvida em trabalhos assalariados fora da propriedade, no mercado de trabalho indicado por Sawyer e Kitamura et al. Evidentemente, essa grande atividade extrapropriedade não foi determinada no estudo feito por Costa. Grossmann (1995, p. 31 e p. 34) faz referência qualitativa ao importante papel do rendimento extrapropriedade no Sistema I, como, por exemplo, rendimento de ensino, pensões, trabalho no empreendimento do irmão. Uma pensão de 90 dólares/mês representa, sozinha, mais de um terço do rendimento bruto e, devido ao alto consumo pessoal, chega a $92 \%$ do valor monetário de venda dos bens agrícolas ${ }^{23}$.

A relação entre o volume da mão-de-obra potencial, a utilização efetiva da mão-de-obra e o rendimento extrapropriedade requer um esclarecimento empírico mais acurado, não apenas com relação ao Sistema I, mas também para os Sistemas II e III, que são caracterizados pela crescente utilização da grande mão-de-obra familiar (98,6 e 126, respectivamente, em 304 dias/por trabalhador familiar).

O estudo feito pela EMBRAPA, em 1982, forneceu evidências interessantes dessa relação. Como a mão-de-obra familiar foi bem menor em 1982 no Sistema I (com 2,86) e no Sistema III (com mais de 3,3 trabalhadores familiares), foi determinado um número de 84 e 200 dias de trabalho, respectivamente, por trabalhador assalariado (ou seja, 10\% e $20 \%$ do potencial da mão-de-obra familiar em um ano de 300 dias). A conseqüente criação de custos salariais de $16-17 \%$ do valor bruto de produção foi compensada por 110 dias de trabalho extrapropriedade no Sistema I e por rendimentos monetários quatro vezes mais altos no Sistema III.

Ao contrário do estudo feito pela EMBRAPA, Costa analisou, com maiores detalhes, os fatores decisivos responsáveis pelo aumento do

${ }^{23}$ Cálculos próprios.

238 
valor líquido de produção do empreendimento: enquanto o rendimento monetário por área de terra diminuía drasticamente do Sistema I para o III, a intensidade da atividade anual por unidade de mão-de-obra (familiar) aumentava de 98 dias (Sistema I) para 126 (Sistema II) e para 305 (Sistema III), indicando, segundo Costa, uma "extensa mudança de trabalho", pois o aumento de dias de trabalho por ano nos diferentes empreendimentos estava relacionado à diminuição do número de dias de trabalho por hectare, de 189 (I) para 114 (II) e para 65 (III) $)^{24}$. Ao mesmo tempo, o rendimento líquido de um dia normal de trabalho $(r=$ valor líquido de produção dividido pelo número de dias trabalhados) aumentou de 5,8 dólares para 7,5 dólares (Sistema II), especialmente pelo aumento de terra trabalhada por dia de trabalho (hectare trabalhado/dia), o que foi feito para compensar a diminuição do valor líquido de produção por hectare. O processo podia, portanto, ser identificado como "processo extensivo" tde terra. No sitema III, os rendimentos monetários por hectare caíram tanto que não puderam ser compensados pelo aumento da área de terra trabalhada por dia, de modo que a "Iucratividade" dos dias de trabalho diminuiu para 5,9 dólares.

Em termos de modelo de economia familiar, isso significa dizer que, dada a tecnologia relativamente constante, é possível aumentar a eficiência econômica no sentido de fazer crescer os rendimentos líquidos anuais por trabalhador, em virtude da redução do rendimento monetário por hectare e até mesmo por dia de trabalho, por meio de uma estratégia intensiva de terra e trabalho, na qual o número de dias de trabalho por ano, por trabalhador, é aumentado drasticamente (cf. BOSERUP, 1965; TSCHAJ ANOW, 1923). Considerando-se a atual microeconomia neoclássica, esse resultado é um paradoxo, pois liga o aumento de eficiência ao aumento de rendimentos por hectare e/ou por dia de trabalho (ELLIS, 1993).

Costa complementa sua "recompensa" ao trabalhador familiar por um trabalho dominante e uma estratégia intensiva de terra com uma outra classificação, especial para os Sistemas II e III, conforme a média acima e abaixo da disponibilidade de terra e trabalho, além de outras combinações. Todos os empreendimentos com lotes de terra $(>17,7$ hectares de terra cultivada) são caracterizados por vias intensivas em terra e trabalho e começaram, a partir de meados da década de 70, a preparar pastagens e, entre 1978 e 1982, a plantar lavouras permanentes. Tendo consolidado suas pastagens e seus campos de lavoura permanente, esses empreendimentos expandiram-se da década de 80

${ }^{24}$ Cálculos próprios. 
até a década de 90 . Empreendimentos com restrições de terra começaram apenas a preparar pequenas pastagens na década de 70 , mas, a partir de 1982, e especialmente a partir de 1986, passaram a plantar lavouras permanentes de forma intensiva. No entanto, jamais puderam obter a dinâmica de investimento e o valor acumulado dos empreendimentos com lotes de terra.

Havia, porém, significativas diferenças na dinâmica de investimento dentro do grupo com lotes de terra (em média 35-37 ha). Os empreendimentos com uma grande mão-de-obra familiar (Sistema III, com 7,82 ) tenderam a aumentar as pastagens e os campos de lavoura permanente de maneira relativamente simultânea. Graças a esse desenvolvimento, geralmente mais estável, foram capazes de reduzir riscos, acumular grandes rebanhos e pastagens, utilizar sua mão-de-obra familiar de 2346 dias disponíveis. Segundo Costa, exigiam apenas 227 dias de trabalho dos trabalhadores assalariados (0,09 dias de salário por unidade de mão-de-obra familiar). A pesar da fatia relativamente igual e grande de lavouras permanentes (32\%) e de gado (31\%) no valor líquido de produção, esses empreendimentos possuem uma receita líquida maior por unidade (de US\$12 130 a US\$ 15 664), porém um rendimento bem menor por trabalhador familiar (de US\$2 003 a US\$ 3515 ) do que o grupo dos empreendimentos com menor mão-deobra familiar, no qual o investimento dinâmico estava voltado para as lavouras permanentes desde o início, com um subseqüente atraso na preparação de pastagens. Aqui, a fatia representada pelo gado no valor líquido de produção atingia $5 \%$ em 1993, e as lavouras permanentes, $45 \%$. Entretanto, devido à grande demanda de mão-de-obra nas lavouras permanentes (1 837 dias de trabalho), esses empreendimentos (com mão-de-obra familiar de 3,45 e uma performance potencial de trabalho de 1035 dias) exigem pelo menos 802 dias de trabalho dos trabalhadores assalariados ${ }^{25}$.

Devido à grande dependência do trabalho assalariado, esse grupo de empreendimentos atinge os limites da economia familiar. Segundo Costa, por esse motivo é mais suscetível às flutuações dos preços de mercado, o que representa um risco maior. A pesar da renda anual por trabalhador familiar ser maior, por causa da utilização otimizada da mãode-obra familiar e do maior número de trabalhadores assalariados, os rendimentos por dia de trabalho (US\$ 6 60) ficam apenas um pouco acima dos valores médios de rendimento para todos os empreendimentos, mas os rendimentos por unidade de área (total: US $\$ 332$ por hecta-

${ }^{25}$ Cálculos próprios, baseados em Costa (1996c).

240 
re) ficam abaixo desses valores. Os empreendimentos com menos mãode-obra familiar e menos terras apresentam claramente rendimentos mais altos por dia de trabalho e por hectare, mesmo que sua renda líquida por trabalhador familiar seja de apenas US\$ 1560 . Segundo Costa, esse contraste explica-se pelos investimentos - geralmente fruto de recursos pessoais - feitos em lavouras permanentes e pastagens a partir da década de 70, os quais, em 1996, atingiram US\$ $12738 \mathrm{em}$ empreendimentos com lotes de terra e pequena mão-de-obra familiar e US\$15 388 em empreendimentos com lotes de terra e maior disponibilidade de mão-de-obra familiar. Os empreendimentos com menos terra começaram a investir apenas na década de 80 , e seus investimentos apenas atingiram US\$ 4000 a US\$5000 por volta de 1993.

Essa dinâmica de investimento surpreendentemente alta pode ser explicada apenas pelo aumento da utilização da mão-de-obra familiar não remunerada. Se incluíssemos o volume de mão-de-obra familiar efetivamente utilizado, de até 2300 dias de trabalho por ano, com um salário mínimo local de US\$ 90 por mês ou US\$ 3 por dia, os cálculos de rendimento por dia de trabalho seriam drasticamente reduzidos, e 0 rendimento por unidade de área cairia até mesmo para uma faixa deficitária. Se os agricultores tivessem seguido os cálculos do modelo neoclássico, a dinâmica de altos investimentos, sem grandes fontes externas de financiamento, poderia ser explicada apenas em casos excepcionais: a menos que fosse levado em consideração o trabal ho urbano com rendimentos altos, acima da média. Entretanto, se partirmos da hipótese realista de 90 dólares/mês, a remuneração máxima que os trabalhadores familiares poderiam obter fora da propriedade seria de US\$ 1 088. Esse rendimento anual é maior do que a média (incluindo o valor monetário do consumo pessoal ao preço do produtor) dos trabalhadores familiares dos Sistemas I (US\$ 572) e II (US\$ 938), porém menor do que o do Sistema III (US\$ 1 088).

Presumindo-se a existência de mercados de trabalho em pleno funcionamento, a constante produção agrícola em quase metade dos empreendimentos seria considerada não lucrativa, se comparada ao possível rendimento obtido fora da propriedade.

Tal afirmativa está obviamente condicionada à possibilidade de emprego em horário integral para todos os trabalhadores familiares, recebendo o salário mínimo, em mercados de trabalho urbanos e rurais. No entanto, se descartarmos essa hipótese, como é normal nos modelos de agricultura familiar, a continuidade da produção pode ser explicada, ainda que os rendimentos anuais dos trabalhadores familiares fiquem abaixo dos custos de oportunidade: mesmo quando apenas metade da mão- 
de-obra familiar é composta por homens e as mulheres e crianças encontram empregos de horário integral, durante o ano todo, com salário mínimo, a produção continuada dentro do empreendimento familiar é ainda mais rentável do que apenas o trabalho assalariado - o que não exclui a combinação ideal de trabalho assalariado de meio período fora da propriedade e a continuação da produção num nível reduzido. Esse efeito é reforçado pelo fato de que o trabalhador assalariado paga mais por sua alimentação (preço de mercado) do que os produtores que consomem o que produzem (abaixo do preço do produtor). Se o consumo pessoal fosse valorizado pelo preço do varejo, o mesmo efeito seria observado. Os cálculos de tomada de decisão, sozinhos, estão ligados à garantia de alimentação a longo prazo para a família e podem geralmente dar apoio à continuação da produção, apesar dos custos de oportunidade não lucrativos a menos que seja presumida uma drástica queda na fertilidade do solo e na produtividade física da lavoura, em razão de períodos de pousio reduzidos (crise da agricultura itinerante), uma queda a longo prazo nos rendimentos monetários por dia de trabalho e unidade de área para produtos vitais, devido a uma queda de preços no mercado, e uma estrutura estática de fornecimento ou oportunidades de rendimento acima da média em empregos urbanos qualificados. Uma vez que esse conjunto de eventos pode ocorrer em economias familiares, interligados de modos diferentes, seria útil um uso limitado de cálculos de oportunidade de custos para uma análise das conexões complexas entre diferentes cálculos socioeconômicos e fatores de contexto estrutural. De qualquer modo, é necessário um período de observação suficientemente longo para dar sentido às previsões de tendências para a sustentabilidade socioeconômica (e ecológica) das propriedades de pequenos agricultores.

Assim, a simples comparação do rendimento por dia de trabalho e do salário médio diário é menos significativa quando se desconhece a utilização anual do volume de trabalho potencial da mão-de-obra familiar: o rendimento aparentemente alto, comparado ao salário mínimo diário de US\$ 3 por dia de trabalho no Sistema II (US\$ 7,5), devido à utilização anual de apenas 125 dias, soma-se ao rendimento anual do trabalhador familiar, de apenas US\$938 (que está abaixo do rendimento anual do salário mínimo de US\$1 088). 0 rendimento diário mais baixo do Sistema III, de US\$ 5,9, entretanto, gera uma renda anual de US\$ 1088 por causa da utilização de 304 dias, enquanto no Sistema I, com uma renda diária de US\$ 5,8 e uma subutilização generalizada da mão-de-obra (96 dias/trabalhador/ano), atinge-se uma renda anual de apenas US\$ 572 (ou seja, metade da renda de um trabalhador que recebe 0 salário mínimo).

242 
Contra esse cenário de simples aritmética, a comparação entre diferentes rendimentos por dia (também chamados de valor ou rendimento do dia de trabalho), freqüentemente apontada na literatura como a possível causa dos processos de decisão dos pequenos agricultores, deve ser considerada, especialmente quando está fora do contexto do nível de utilização, dos preços relativos e do rendimento anual por trabalhador familiar. Nos estudos empíricos realizados em Marabá, na Transamazônica e em Paragominas, tal comparação é predominante, e a partir dela é imediatamente determinado o interesse racional dos produtores e são feitas recomendações para o aumento ou a diminuição da produção agrícola (CASTELLANET; SIMÕES; CELESTINO FILHO, 1994; FIGUEIREDO, 1994; REYNAL et al., 1996; TONIOLO; UHL, 1996). O valor de produção por hectare (US\$/ha) é dividido por trabalhador por hectare (dias/ha), e o "valor de um dia de trabalho" representa conseqüentemente 0 "rendimento do trabalhador familiar", que supostamente orienta os processos de tomada de decisão racional dos agricultores. Embora essa forma de determinação do valor do dia de trabalho traga à lembrança os resultados da forma de determinação encontrada por Costa, esse autor dividiu o rendimento anual por trabalhador familiar pelo número de dias trabalhados por trabalhador, fornecendo o ponto fundamental de comparação (rendimento anual "por hectare" em vez de "por trabalhador familiar"), especialmente quando se leva em conta que 0 limitado significado de rendimento por dia, dados os preços predominantes no mercado, está ligado ao nível de utilização da mão-de-obra.

Esse sentido limitado é especialmente observado no estudo feito em Marabá (REYNAL et al., 1996). No início da década de 90, a taxa de rendimento diário do gado (US\$4-7,5), dependente da produtividade física bastante variável (1:3 para o arroz), de preços de mercado e custos de transporte (1:2), era maior do que a da lavoura anual de arroz (US\$ 1-8) e da mandioca (US\$ 1,3-10), em Marabá. Isso, somado aos aumentos no preço das terras para pastagens, foi suficiente para convencer Reynal et al. do cálculo racional dos agricultores que os levou a investir em pastagens e em gado como estratégia para acumular riqueza nas fronteiras agrícolas. É interessante observar que, para calcular o valor de um dia de trabalho, foi utilizado não o preço efetivo de venda do gado, mas o valor de mercado, geralmente superestimado (uma vez que as vendas eram menores do que as compras), de um rebanho em crescimento. Ao contrário do consumo pessoal efetivo no ano corrente, aqui - como ocorre nas lavouras permanentes -, o valor esperado de venda de um investimento é calculado como capital crescente. A concretização desse ganho de capital é questionável quando a maioria dos 
empreendimentos quer ou precisa vender rebanhos, em vez de continuar a aumentá-los.

As vantagens da criação de gado - como a produtividade de trabalho mais alta do que nas lavouras anuais, uma otimização da ocupação da mão- de-obra familiar durante a estação seca, a reduzida dependência do estado das vias de transporte (o gado anda até o mercado), a alta estabilidade de preços e seu conseqüente bom uso como capital vivo de poupança - podem parecer um motivo plausível para os produtores, porém dificilmente resistem a uma análise econômica com um horizonte de longo prazo. Os preços são estáveis somente porque as vendas são baixas (fase de acumulação), o suposto valor diário é deduzido do gado não vendido e não consumido, em um mercado com preços superestimados, e a função do gado como riqueza pode ser importante entre as fases, mas pode também levar à sua drástica depreciação quando as vendas aumentam.

Noções semelhantes aplicam-se à Transamazônica, onde a expansão da pecuária faz muito pouco para suprir as lavouras anuais, como o arroz e a mandioca (como em Marabá), porém tem sido utilizada desde o final da década de 80 como forma de sair da dupla crise das lavouras permanentes de pimenta e cacau (CASTELLANET; SIMÕES; CELESTINO FILHO, 1994; FAO; INCRA, 1995). Os preços de mercado em Altamira, em reação aos preços do mercado mundial, caíram a partir de 1987, tendo atingido seu ponto mais baixo em 1993, quando o preço da pimenta e do cacau chegou a $\mathrm{R} \$ 0,40 / \mathrm{kg}$. Paralelamente à queda dos preços, doenças nas duas lavouras causaram uma queda na produtividade física, que poderia ter sido superada, pelo menos no caso do cacau, com um aumento do preço de mercado por meio da proteção manual das plantas (ou seja, aplicação de fungicidas). Conforme um estudo feito pelo Laboratório Agroecológico da Transamazônica (LAET), o rendimento por dia de trabalho para a pimenta caiu para $R \$ 7,20$ e, mo caso do cacau, para $\mathrm{R} \$ 6,30$, em 1993, porém ainda assim ficou maior do que o do gado $(R \$ 5)$ e bem acima do valor do arroz $(R \$ 1,90)$ e da farinha de mandioca (R\$2,80) (CASTELLANET; SIMÕES; CELESTINO FILHO, 1994; PAET, 1994). Somente o drástico "recrescimento" dos preços de mercado (a uma constante, porém baixa, taxa de produtividade física) aumentou as rendas por dia para a pimenta ( $\mathrm{R} \$ 28)$ e para 0 cacau ( $R \$ 12,40)$, e mesmo para o arroz ( $R \$ 6,00)$, em 1995 , enquanto o rendimento do gado e da mandioca permaneceram os mesmos ${ }^{26}$. Se

${ }^{26}$ Cálculos próprios, a partir de uma rápida dedução dos valores de produção muito altos em Castellanet et al. (1994) e dos preços indicados em FAO e INCRA (1995).

244 
ainda assim os empreendimentos familiares aumentaram seus sistemas de produção para incluir rebanhos bovinos, isso não pode dever-se a problemas com lavouras permanentes (riscos de produção mais altos devido a flutuações de mercado e doenças) ou à aparente vantagem da criação de gado: absorção baixa e regular da mão-de-obra familiar ao longo do ano (7 dias/ha para o gado, comparado a 45 dias/ha para o cacau, 55 dias/ha para a pimenta, 70 dias/ha para o arroz e 150 dias/ha para a farinha de mandioca) e caráter subjetivo de maior riqueza, conferido à criação de gado (VEIGA; TOURRAND; QUANZ, 1995). A importância em longo prazo desses motivos dados pelo produtor para a criação de gado pode ser avaliada apenas pela comparação com o rendimento anual por trabalhador familiar.

Além de Costa, apenas o estudo da FAO utiliza o valor líquido da produção por trabalhador familiar como chave da comparação das vantagens dos produtos e sistemas de produção; embaralha-se, porém, nas comparações dos valores diários, caindo nas contradições já mencionadas anteriormente (FAO; INCRA, 1995). No entanto, sua amostra de cálculo para 1995 demonstra que o maior rendimento anual por trabalhador familiar (R\$1340 para o cacau) apresenta uma baixa taxa diária $(R \$ 7,60)$, quando a taxa de ocupação por trabalhador familiar (176 dias de trabalho/ano) é alta, e esses valores diários mais altos ( $R \$ 11,20$ para arroz e milho, $\mathrm{R} \$ 14,10$ para café), com taxas de ocupação mais baixas (74 e 39 dias, respectivamente), resultam em rendimentos anuais mais baixos de 830 e $R \$ 550$, respectivamente. As taxas de ocupação da mão-de-obra familiar ("utilização da mão-de-obra"), conforme mencionado, são colocadas em segundo plano, pela influência dos preços de mercado, das quedas de produtividade física provocadas por doenças, etc. 0 estudo do LAET, de 1993, revelou que a pimenta, especialmente devido à baixa produção $(800 \mathrm{~kg} / \mathrm{ha}$ em vez de $1300 \mathrm{~kg} / \mathrm{ha})$, teve o mais baixo valor líquido de produção por trabalhador familiar ( $R$ \$ 350 ), embora o preço de mercado tenha aumentado para $R \$ 0,80 / \mathrm{kg}$; as baixas taxas de ocupação (45 dias de trabalho/ha) levaram a rendimentos diários $(R \$ 7,70)$ comparáveis aos do cacau. Ao serem incluídos os aumentos de preço ocorridos em 1995, que são apenas parcialmente considerados pelos autores em seus modelos de cálculo, o rendimento anual por trabalhador familiar aumentou para $\mathrm{R} \$ 2160$ no caso do cacau e para $\mathrm{R} \$ 628$ no caso da pimenta, de forma que o rendimento diário da pimenta $(R \$ 13,90)$ é maior do que o do cacau $(R \$ 12,30)$, do arroz/milho $(R \$ 11,20)$ e do gado $(R \$ 6)^{27}$. Ainda assim, o rendimento

${ }^{27}$ Cálculos próprios. 
anual por trabalhador familiar, no caso da pimenta, fica abaixo do rendimento do gado ( $R \$ 735$ ) e do arroz ( $R$ \$ 830), com taxas de ocupação, respectivamente, de 120 e 74 dias de trabalho por trabalhador familiar por ano.

Apesar das dificuldades metodológicas no cálculo de indicadores para as vantagens econômicas, ao compararmos os estudos realizados na Transamazônica pelo LAET (CASTELLANET; SIMÕES; CELESTINO FILHO, 1994; PAET, 1994) e pela FAO, o significado extremamente limitado de uma comparação de rendimento por dia de trabalho (FAO; INCRA, 1995, p. 28). Segundo as hipóteses propostas no trabalho do LAET, a expansão da pecuária e a continuação da produção de arroz podem ser explicadas somente por meio dessas comparações, ou apenas com suposições adicionais. Se o indicador "rendimento anual por trabalhador familiar" (conforme o estudo da FAO) fosse utilizado, os dois processos poderiam ser explicados sem hipóteses adicionais. Entretanto, a principal deficiência do estudo da FAO reside no fato de seu modelo calcular apenas as vantagens dos produtos individuais, embora o indicador seja utilizado para comparar sistemas de produção.

A pesar de destacar o rendimento anual por trabalhador familiar em seu estudo, Costa (1996b) também utiliza o rendimento diário como base para o processo de tomada de decisão dos agricultores. Esse é o motivo pelo qual ele não indica por que os empreendimentos com lotes de terra não investem todo seu tempo na produção comparativamente mais lucrativa de lavouras permanentes, com rendimento diário de US\$ 7-7,50, em oposição às lavouras anuais (US\$1,30-2,30/dia), com referência à taxa de ocupação e aos níveis relativos de preço. Em vez disso, no entanto, ele explica o aparente paradoxo, com referência ao retorno parcialmente mais alto por dia, da ligação estreita entre lavouras anuais e a pequena produção animal, para a qual é direcionada a maior parte da produção do milho e grande parte da mandioca e do arroz.

No grupo de empreendimentos com lotes de terra, porém com pequena mão-de-obra familiar, o retorno diário aumenta de US\$2,30 (apenas lavouras anuais) para US\$ 8,30 devido à grande fatia dos pequenos animais no valor de produção (36,5\%). Assim, ficam acima dos valores das lavouras permanentes, porém bem abaixo dos valores do gado. O "complexo lavoura anual/criação de pequenos animais", com uma fatia de $50 \%$ do valor líquido da produção, ultrapassa a fatia das lavouras permanentes (45\%) e a do gado (5\%).

No grupo que possui lotes de terra e uma grande quantidade de mão-de-obra familiar, o rendimento diário nas lavouras anuais aumentou de US\$ 1,90 para US\$5,21, pela influência dos pequenos animais, 
porém não alcançou os níveis das lavouras permanentes (US\$ 7,50 ) ou do gado (US\$ 19). A fatia do "complexo lavoura anual/criação de pequenos animais" ficou em $37 \%$ do valor das lavouras permanentes (32\%) e do gado (31\%).

A importância da criação de pequenos animais (normalmente escondida) para o consumo pessoal, o valor de produção e o aumento do rendimento diário é definitivamente grande. A explicação de Costa para a continuada produção de lavouras anuais, a despeito do baixo rendimento diário, bem como para o alto rendimento anual dos empreendimentos com lotes de terra, porém com uma pequena mão-de-obra, merece ser criticamente reexaminada.

Segundo Costa admite livremente, a interpretação dos resultados obtidos, sem muito aprofundamento, sobre o número de galinhas, ovos e porcos, o número de dias de trabalho exigido para mantê-los e seu valor líquido de produção deve ser acol hida com certa reserva. Por outro lado conforme Costa também propõe -, podemos presumir que a manutenção de pequenos animais "correndo por aí" requer menos trabalho e que essa carga de trabalho pode ser considerada como "marginal" no sentido pensado por Tepich (1973) (feito por crianças e mulheres, durante os trabaIhos domésticos, e pelos homens, durante seu "tempo livre"). Devido a esse caráter invisível e disperso, é difícil calcular a carga de trabalho dentro dos dias de trabalho, o que também é mencionada por Costa. Os rendimentos anuais médios da criação de pequenos animais - US\$ 3657 e US\$ 4 427, respectivamente, por empreendimento e de US\$ 468 e US\$ 1403, respectivamente, por trabalhador familiar - não são apenas muito mais altos do que os das lavouras anuais, mas no último exemplo quase atingem 0 valor das lavouras permanentes.

O principal problema desses cálculos está nos valores não plausíveis para os dias de trabalho necessários. Os valores de rendimento diário propostos por Costa - US $\$ 3,9$ e US $\$ 6,06$ respectivamente - implicam uma carga de trabalho anual de 933 e 731 dias, respectivamente, por empreendimento ou de 119 e 212 dias, respectivamente, por trabalhador familiar ${ }^{28}$. Faria mais sentido interpretar esse trabalho como tempo de trabalho adicional marginal em dias de trabalho na lavoura anual (tratar com milho e subprodutos do arroz e mandioca). Se quisermos levar a sério os cálculos em dias de trabalho, o número de dias de trabalho por ano nas lavouras anuais e com pequenos animais elevar-se-ia para 2568 e 3506 dias, respectivamente, por empreendimento e para 330 e 423 dias, respectivamente, por trabalhador familiar. Se excluirmos esse caso

${ }^{28}$ Cálculos próprios. 
como algo não plausível e transferirmos a renda obtida com a criação de pequenos animais para uma área de lavouras anuais, a renda por unidade de área, em ambos os sistemas, passaria de US\$ 239 para US\$ 639 e de US\$ 431 para US\$1578, atingindo assim, e no último exemplo claramente ultrapassando, o rendimento por hectare das lavouras permanentes (US\$ 687 e US\$ 760, respectivamente). A renda anual por trabalhador familiar (US\$ 727 e US\$1765, respectivamente) também ficaria acima da renda das lavouras permanentes (e do gado).

Esses valores, no entanto, são problemáticos, devido às dificuldades de coleta de dados. 0 papel decisivo da escalada das lavouras permanentes para superar a crise da agricultura itinerante também precisa ser revisto. Isso pode ser feito pela comparação do número de dias de trabalho exigidos por lavoura com seu valor líquido de produção, graças às informações existentes nas tabelas de Costa (1997b). Porém, na lista de valores de produção, é incluída somente a criação de pequenos animais, mas não consta o número anual de dias necessários, o que diria bastante sobre a interpretação acima, relativa ao seu papel como um "aumentador" de receita (renda).

Na classificação de dias de trabalho por produto, as perguntas de Costa sobre o motivo pelo qual os agricultores não investem mais tempo em produtos mais rentáveis tornam-se ainda mais claras. Ao incluir a criação de pequenos animais, uma comparação das lavouras anuais e permanentes e da produção de gado revela que, anualmente ${ }^{29}$ (Quadro 10 e 11).

\begin{tabular}{|l|c|}
\hline Lavoura & \% anual de dias de trabalho \\
\hline Lavouras anuais (total) & 55 \\
\hline feijão & 19,4 \\
\hline mandioca & 18,6 \\
\hline milho & 12, \\
\hline arroz & 4,4 \\
\hline Lavouras permanentes (total) & 27 \\
\hline laranja & 13,7 \\
\hline pimenta & 8,8 \\
\hline maracujá & 2,3 \\
\hline coco & 2,7 \\
\hline Gado & 8,8 \\
\hline
\end{tabular}

Quadro 10: Capitão Poço - Distribuição dos dias trabalhados entre produtores agrários.

Fonte: COSTA, 1997.

${ }^{29}$ Cálculos próprios, segundo Costa (1997b).

248 
Análise socioeconômica dos sistemas de uso de terra por pequenos produtores agrários na Amazônia oriental

\begin{tabular}{|l|c|}
\hline Lavoura & \% anual do valor líquido de produção \\
\hline Lavouras anuais (total) & 32 \\
\hline feijão & 5,5 \\
\hline mandioca & 16,4 \\
\hline milho & 1,8 \\
\hline arroz & 8,3 \\
\hline Lavouras permanentes (total) & 50 \\
\hline laranja & 1,6 \\
\hline pimenta & 30 \\
\hline maracujá & 16,6 \\
\hline coco & 2,1 \\
\hline Gado & 14,1 \\
\hline
\end{tabular}

Quadro 11: Classificação do valor líquido do produto - relação

contrária

Fonte: COSTA, 1997.

Entretanto, ao contrário dos dados de Costa acima mencionados, 0 rendimento por dia para todos os empreendimentos de lavoura anual (US\$ 2,16 ) e para pequenos animais (US\$ 2,9 ) aumentou para US\$ 5 , ficando abaixo do valor de mercado para lavouras permanentes (US\$ 8,9 ) e gado (US\$ 7,8 ), porém acima do valor da mandioca (US\$ 4,3), da laranja (US\$ 0,6) e do coco (US\$3,6). Valores extremos, que podem ser baseados em erros de mensuração, foram apontados para o algodão (US\$ 535) e o açaí (US\$ 224).

A já mencionada relação entre baixos valores de rendimento diário e a alta carga de trabalho por ano por trabalhador familiar é observada nas lavouras anuais (121 dias/trabalhador e US\$ 2,6/dia), nas lavouras permanentes (59,6 dias/trabalhador e US\$ 9/dia) e na criação de gado (19,3 dias/trabalhador e US\$7,8/dia).

A maior intensidade de trabalho das lavouras anuais é observada na carga de trabalho por unidade de área: com base nos dados de Costa, uma carga média de 82,4 dias/ha é observada para as 4 lavouras permanentes, com um total de 428 hectares; a carga de trabalho para as lavouras anuais é o dobro para uma área semelhante (entre 388 ha e 577 ha, considerando-se o pagamento dobrado para consórcios) e, para a área de 388,8 hectares, chega até mesmo a 184 dias/ha. A variação nas lavouras permanentes também foi muito alta: pimenta

${ }^{30}$ Cálculos próprios. 
(47 ha) e coco ( 35 ha) obtiveram valores de 235 dias/ha e 119 dias/ha, enquanto laranja (264 ha) e maracujá (87 ha) obtiveram valores menores (67 dias/ha e 34 dias/ha) ${ }^{31}$.

Apesar da inclusão dos dados problemáticos sobre a criação de pequenos animais, a pergunta inicial de Costa permanece sem resposta: Por que os agricultores gastam o dobro de tempo por trabalhador familiar cultivando lavouras anuais, apesar de obterem rendimento diário equivalente a um quarto do rendimento das lavouras permanentes? A resposta para Costa já foi mencionada: por meio da inclusão do rendimento da criação de pequenos animais e da criação do chamado "complexo lavoura anual/criação de pequenos animais".

${ }^{31}$ Cálculos próprios.

250 
Análise socioeconômica dos sistemas de uso de terra por pequenos produtores agrários na Amazônia oriental

\section{CONSIDERAÇÕES FINAIS}

De acordo com o resultado dos dados mencionados, mesmo com a inclusão dos dados problemáticos sobre a criação de pequenos animais, a pergunta inicial de Costa permanece sem resposta: Por que, em comparação com as lavouras permanentes no total, os agricultores gastam o dobro de tempo por trabalhador familiar cultivando lavouras anuais, apesar de obterem rendimento diário equivalente a um quarto do rendimento das lavouras permanentes?

\section{$x \times \times \times \times x$}

A resposta à pergunta de Costa já foi mencionada: por meio da inclusão do rendimento da criação de pequenos animais, a produção líquida, junto com as culturas anuais, alcança por trabalhador familiar um valor bem acima das culturas permanentes. Mas com um detalhe importante: devido à alta carga de trabalho por trabalhador familiar, que alcança o dobro das culturas permanentes, o valor do dia do trabalhador fica bem abaixo das culturas permanentes.

Então, a conclusão de Costa de que a pequena criação seria capaz de aumentar o valor das culturas anuais até o nível das culturas permanentes é válida apenas para os rendimentos anuais, não é válida para os rendimentos diários. Mas, como Costa privilegia neste artigo (como a grande maioria dos economistas agrários com formação neoclássica, infelizmente também Chayanov) os rendimentos (lucros) diários para mostrar (na verdade, só postular) a predominância de uma tendência equilibrador na distribuição do trabalho e da terra entre as culturas, ele não pode fornecer uma explicação coerente para aquela contradição.

Mas uma explicação para essa contradição é possível e deveria ser buscada de duas formas. Por um lado, seguindo a mesma metodologia de Costa, mas privilegiando, como ele faz em outros artigos, os rendimentos anuais por trabalhador e não os rendimentos diários. Isso já foi mostrado e discutidos vários vezes no texto. A variável-chave nesse sentido é a carga de trabalho média do trabalho familiar, que pode ser alta não somente devido à intensificação do processo produtivo, mas também devido à existência apenas parcial de oportunidades de trabal hos mais bem remunerados no mercado local (custos de oportunidade baixos). 
Por outro lado, é pertinente deixar de lado a premissa da existência de um único cálculo econômico para todas as esferas e categorias da agricultura familiar e introduzir um modelo bem mais complexo de processos decisórios de agricultores familiares, com horizontes temporais diferenciados e pesos diferentes para a reprodução da mão-de-obra familiar como principal objetivo.

0 enfoque da agricultura familiar permite distinguir objetivos diversos em condições de uma racionalidade de ação limitada ou contraditória (bounded rationality) que são ligados a dimensões diferentes dentro da unidade familiar. Na área da segurança alimentar, predominam estratégias de médio e de longo prazos de sobrevivência, redução de risco, valorização do autoconsumo e, conseqüentemente, da "alternatividade" do "cálculo camponês" na produção de alimentos. Com os dados da pesquisa de Costa, foi possível detectar essa tendência até para o caso de Capitão Poço: embora as culturas temporárias (sobretudo a mandioca) tivessem rendimentos anuais por hectare, por dia trabalhado e por unidade de mão-de-obra familiar bem inferiores aos das culturas perenes, os camponeses alocaram na média o dobro de dias trabalhados naqueles cultivos em relação às perenes, aparentemente mais rentáveis. Também quando se inclui, como Costa, o alto valor da pequena criação no das culturas temporárias, não se al cançam os valores das permanentes, a não ser que se desconsiderem as árvores frutíferas do quintal (cálculos próprios, com base nos dados de COSTA, 1997b). Provavelmente é mais plausível não partir de um único cálculo camponês, mas considerar pesos diferentes para a segurança alimentar em qualquer ano, o que formalmente se pode fazer levando em conta um prêmio de risco.

Na área do ingresso monetário anual familiar, pode dominar uma estratégia de maximização de curto prazo (aproveitando preços melhores e chances inesperadas de mercado) que, nas condições do processo de trabalho agrícola, exige tempo e, por isso, normalmente não se distingue da maximização do rendimento anual por unidade do trabalho familiar (e não da área ou da hora trabalhada). Já na área do melhoramento a longo prazo da situação econômica, predomina uma orientação de investimentos mais arriscados em plantações de culturas perenes, pastos e acumulação patrimonial de gado (OZÓRIO DE ALMEIDA et al., 1992).

Ainda não é possível dizer muito sobre o peso relativo desses cálculos econômicos conflitantes na tomada de decisão na agricultura familiar na Amazônia, porque poucos modelos e trabalhos empíricos abordaram esses cálculos de maneira sistemática (COSTA, 1994, 1997a; ELLIS, 1993; KITAMURA et al., 1983; OZÓRIO DE ALMEIDA, 1992;

252 
OZÓRIO DE ALMEIDA et al., 1992; SANTANA, 1990). Um melhor esclarecimento dos processos de tomada de decisão na pequena produção é fundamental também para a aplicação prática de recomendações elaboradas, como as do projeto SHIFT Capoeira, para priorizar vantagens de médio prazo em detrimento das vantagens de curto prazo, nesse caso, eliminar o uso do fogo como técnica de fertilização, o que diminui a perda de nutrientes da capoeira a médio e longo prazos, mas implica também gastos maiores para a compra de adubo no primeiro ano para compensar esse efeito.

O esclarecimento das estruturas mistas dos cálculos socioeconômicos dos pequenos agricultores poderia indicar uma zona de convergência entre sustentabilidade ecológica, consolidação econômica e melhoramento das condições de vida.

Nesse sentido, o fato de a pesquisa concentrar-se nas características da agricultura familiar como ponto de partida não exclui a consideração de opções para a mão-de-obra familiar no mercado local e regional de trabalho, incluindo os cálculos das vantagens comparativas. Em contraste com os modelos de farm-household, o nosso enfoque assume o uso limitado, não generalizado, de cálculos de custos de oportunidade. Dessa maneira, evita-se o problema de não poder explicar, por exemplo, a produção contínua de mandioca, embora signifique balanços anuais negativos (KITAMURA, 1982). Esse enfoque também não exclui o uso temporário de mão-de-obra externa. 0 elemento central da abordagem é a substituição dos cálculos de rentabilidade convencionais (por exemplo, rendimento por hectare e por dia de trabalho) pelo rendimento anual bruto ou líquido por mão-de-obra familiar nas decisões na agricultura familiar (COSTA, 1994).

Além disso, a construção das estruturas de tomada de decisão na agricultura familiar em condições agroecológicas e socioeconômicas variáveis também requer um enfoque metodológico mais amplo, que transgrida os limites da análise. É preciso considerar tanto a dimensão histórica dos sistemas de cultivo e produção, os fatores socioeconômicos e as características agroecológicas de um sistema agrícola regional como também os cálculos de custos e benefícios relacionados a essas condições. O enfoque francês do sistema de produção (MAZOYER, 1987; DUFUMIER, 1996) oferece essa possibilidade de combinar a economia agrícola com a análise de agroecossistemas. 


\section{REFERÊNCIAS}

ALMEIDA, A. L. O. de. Colonização dirigida na Amazônia. Rio de J aneiro: IPEA, 1992.

ALMEIDA, A. L. O. de. CAMPARI, J. S. Sustainable Settlement in the Brazilian Amazon. Washington, D.C.: World Bank; Oxford: Oxford University Press, 1995.

ALMEIDA, A. L. O. de; SANTOS, A.; ALVES, A.; MORAIS, M. A colonização sustentável da Amazônia. Brasília, DF: IPEA, 1992. Texto para Discussão, $\mathrm{n}^{\circ} .266$.

ALVIM, P. T. The Balance between Conservation and Utilization in the Humid Tropics with Special Reference to Amazonian Brazil. In: PRANCE, G. T.; ELIAS, T. S. (Ed.). Extinction is Forever. Bronx, NY: New York Botanical Garden, 1977. p. 347-353.

ALVIM, P. T. Tecnologias apropriadas para a agricultura nos trópicos úmidos. Agrotrópica, [S.I.], v. 1, n. 1, p. 5-26, 1989.

ALVIM, P. T. Agricultura apropriada para uso contínuo dos solos na região Amazônica. Espaço, Ambiente, Planejamento, [S.I.], v. 11, n. 2, p. 1-71, 1990.

AMANOR, K. S. The New Frontier. Farmers' Response to Land Degradation. A West African Study. London, Genf: Zed Books, UNRISD, 1994.

ANDERSON, A. B. (Ed.). Alternatives to Deforestation: Steps Towards Sustainable Use of the Amazon Rain Forest. New York: Columbia University Press, 1990a.

ANDERSON, A. B. Deforestation in Amazonia: Dynamics, Causes and Alternatives. In: ANDERSON, A. B. (Ed.). Alternatives to Deforestation: Steps Toward Sustainable Use of the Amazon Rain Forest. New York: Columbia University Press, 1990b.

ANDERSON, A. B. Extraction and Forest Management by Rural Inhabitants in the Amazon Estuary. In: ANDERSON, A. B. (Ed.). Alternatives to Deforestation: Steps Toward Sustainable Use of the Amazon Rain Forest. New York: Columbia University Press, 1990c.

ANDERSON, A. B.; SWIFT, M. J . Decomposition in Tropical Forests. In: SUTTON, S. L.; WHITMORE, T. C.; CHADWICK, A. C. (Ed.). Tropical 
Rain Forest: Ecology and Management. Oxford: Blackwell Scientific Publications, 1983. p. 287-309.

ARAGUÁS-ARAGUÁS, L.; ROZANSKI, K.; PLATA BEDMAR, A.; TUNDIS VITAL, A. R.; TANCREDI, A. C.; FRANKEN, W. Changes of Soil Water Balance Due to Forest Clearing in the Central Amazon Region. In: SOLUTIONS '95, Managing the Effects of Man's Activities on Groundwater. IAH International Congress XXVI, J une 4-10 1995. Edmonton: MowTechnology Ltd, 1995. 1 CD-ROM.

AY, P. Die Steigerung der Maniokproduktion in lokalen Systemen als Beitrag zur Ernährungssicherung. Peripherie, Nr. 63, S. 73-101, 1996.

BARBOSA, F. Desempenho econômico das principais culturas do Estado do Pará. Belém: SAGRI, 1981.

BASA. FNO. Relatório do exercício de 1996. Belém, 1997.

BASTOS, T. X. O estado atual dos conhecimentos das condições climáticas da Amazônia brasileira. In: INSTITUTO DE PESQUISA AGROPECUÁRIA DO NORTE (Org.). Zoneamento Agrícola da Amazônia. Belém, 1972 (Bol. Técn. 54).

BASTOS, T. X. O clima da Amazônia brasileira segundo Köppen. Belém: EMBRAPA-CPATU, 1982.

BASTOS, T. X. et al. 0 estado atual dos conhecimentos de clima da Amazônia brasileira com finalidade agrícola. In: EMBRAPA-CPATU (Org.). Anais do Primeiro Simpósio do Trópico Úmido. Belém: EMBRAPA-CPATU, 1986. p. 19-36. V. I: Clima e Solo.

BLACK, G. A. Notas sobre os tipos de vegetação do Oiapoque. Rev. Soc. Agr. e Vet., [S.I.], n. 4, p. 15-24, 1950.

BOSERUP, E. The Conditions of Agricultural Growth: The Economics of Agrarian Change under Population Pressure. Chicago: Aldine, 1965.

BRINKMANN, T. Bodennutzungssysteme. In: Handwörterbuch der Staatswissenschaften, Bd. 1 (S. 959-973). J ena: Fischer, 1924.

BROWDER, J. Public Policy and Deforestation in the Brazilian Amazon. In: REPETTO, R.; GILLIS, M. (Ed.). Public Policies and the Misuse of Forest Resources. Cambridge, Mass.: WRI, 1988. 
BRUENIG, E. F. Conservation and Management of Tropical Rainforests: An Integrated A pproach to Sustainability. Wallingford: CAB International, 1966.

BURGER, D.; KITAMURA, P. Importância e viabilidade de uma pequena agricultura sustentada na Amazônia oriental. In: KOHLHEPP, G.; SCHRADER, A. (Org.). Homem e natureza na Amazônia. Tübingen: Geographisches Institut der Universität Tübingen, 1987.

BUSCHBACHER, R.; UHL, C.; SERRÃO, E. A. S. Abandoned Pasture in Eastern Amazonia: Nutrient Stocks in the Soil and Vegetation. J. Ecol., n. 76, p. 682-699, 1988.

CAIN, S. A.; CASTRO, G. M.; PIRES, J. M.; SILVA, N. T. da. Application of Some Phytosociological Techniques to Brazilian Rain Forests. Am. J . Bot., n. $43,1956$.

CAMARGO, F. C. de. Sugestões para o soerguimento econômico do vale amazônico. Belém: Instituto Agronômico do Norte, 1948a.

CAMARGO, F. C. de. Terra e colonização no antigo e novo quaternário da zona da Estrada de Ferro de Bragança, Estado do Pará, Brasil. Boletim do Museu Paraense Emilio Goeldi, Belém, n. 10, p. 123-147, 1948b.

CASTELLANET, C.; SIMÕES, A.; CELESTINO FILHO, P. Diagnóstico preliminar da agricultura familiar na Transamazônica: pistas para pesquisa-desenvolvimento. Vortrag auf dem Seminar am CPATU, 20.10.94 (Ms.), 1994.

CAUFIELD, C. Der Regenwald: Ein schwindendes Paradies. Frankfurt am Main: S. Fischer, 1987.

COCHRANE, T. T.; SANCHEZ, P. A. Land Resources, Soils and Their Management in the Amazon Region: a State of Knowledge Report. In: HECHT, S. (Ed.). Amazonia: Agriculture and Land Use Research. Cali: CIAT, 1982.

COSTA, F. Amazonien - Bauern, Märkte und Kapitalakkumulation. Saarbrücken, Fort Lauderdale: Breitenbach, 1989.

COSTA, F. Ecologismo e questão agrária na Amazônia. Belém: NAEAUFPA, 1992a.

256 
COSTA, F. Valor e preço, exploração e lucro da produção camponesa na Amazônia: crítica à noção de funcionalidade da produção familiar na fronteira agrícola. In: LÉNA, P., A.; OLIVEIRA, E. de (Org.). Amazônia: a fronteira agrícola 20 anos depois. Belém: Cejup, 1992b.

COSTA, F. Racionalidade camponesa e sustentabilidade: elementos teóricos para uma pesquisa sobre agricultura familiar na Amazônia. Belém: NAEA, 1994 (Paper do NAEA, 12).

COSTA, F. Diversidade estrutural e desenvolvimento sustentável: novos supostos de política e planejamento agricola para a Amazônia. Belém: NAEA, 1995 (Paper do NAEA, 44).

COSTA, F. Agricultura familiar em transformação na Amazônia: o caso de Capitão Poço e suas implicações para a política e o planejamento agrícolas regionais. Revista Econômica do Nordeste, [S.I.], v. 27, n. 4, p. 633-672, 1996a.

COSTA, F. Campesinato abre caminho na Amazônia. Ciência Hoje, [S.I.], v. 20, n. 120 , p. 16-23, 1996b.

COSTA, F. Reprodução, tensão e mudança: elementos para uma economia política da agricultura familiar no capitalismo. In: WORKSHOP TEÓRICO ECONOMIA POLÍTICA DA AGRICULTURA, 9.-10., 1996, Campinas. Anais... Campinas: FEA/USP-IE/UNICAMP, 1996c.

COSTA, F. Diversidade estrutural e desenvolvimento sustentável: novos supostos de política de planejamento agrícola para a Amazônia. In: XIMENES, T. (Org.). Perspectivas do desenvolvimento sustentável: uma contribuição para a Amazônia 21. Belém: UFPA/NAEA, 1997a.

COSTA, F. $O$ açaí nos padrões de reprodução de camponeses agrícolas do Nordeste paraense: os casos de Capitão Poço e I rituia. Belém: NAEA, 1997b (Paper do NAEA, 76).

COY, M. J unge Pionierfrontentwicklung in Amazonien. Rondônia: Ursachen und Konsequenzen des neuen "marcha para oeste". Tübinger Beiträge zur Geographischen Lateinamerika-Forschung, H. 1, S. 275302, 1988a.

COY, M. Regionalentwicklung und regionale Entwicklungsplanung an der Peripherie in Amazonien. Probleme und Interessenskonflikte bei der Erschließung einer jungen Pionierfront am Beispiel des brasilianischen 
Bundesstaates Rondônia. Tübingen: Geographisches Institut der Universität Tübingen, 1988b (Tübinger Geographische Studien H. 97, Tübinger Beiträge zur Geographischen Lateinamerika-Forschung H. 5).

CUEVAS, E.; MEDINA, E. Nutrient Dynamics in Amazonian Forest Ecosystems. II. Fine Root Growth, Nutrient Availability and Leaf Litter Decomposition. Oecologia, n. 76, p. 222-235, 1988.

DALE, V.; HOUGHTON, R.; GRAINGER, A.; LUGO, A.; BROWN, S. Emissions of Greenhouse Gases from Tropical Deforestation and Subsequent Uses of the Land. In: NATIONAL RESEARCH COUNCIL (Ed.). Sustainable Agriculture and the Environment in the Humid Tropics. Washington, D.C.: National Academy Press, 1993.

DANTAS, M. Studies on Succession in Cleared Areas of Amazonian Rain Forest. Oxford: Oxford University Press, 1989. PhD Thesis.

DENICH, M. Untersuchungen zur Bedeutung junger Sekundärvegetation für die Nutzungssystemproduktivität im östlichen Amazonasgebiet, Brasilien. Göttingen: Universität Göttingen, 1989 (Göttinger Beiträge zur Land- und Forstwirtschaft in den Tropen und Subtropen 46).

DENICH, M.; KANASHIRO, M. Secondary Vegetation in the Agricultural Landscape of Northeast Pará, Brazil. In: PARROTTA, J. A.; KANASHIRO, M. (Ed.). Proceedings of an International Symposium/Workshop "Management and Rehabilitation of Degraded Lands and Secondary Forests in Amazonia“, 18-22 April 1993, Santarém. Rio Piedras: EMBRAPA-CPATU, International Institute of Tropical Forestry, USDA Forest Service, 1995.

DENICH, M.; VLEK, P.; FÖLSTER, H. Sekundärwald und Brachevegetation in der Kulturlandschaft des östlichen Amazonasgebietes - Funktion und Manipulierbarkeit, SHIFT-Abschlußbericht (1991-1995). Göttingen: Universität Göttingen, 1995.

DINIZ, T. D. de A. S. Caracterização climática da Amazônia Oriental. In: EMBRAPA-CPATU; GTZ (Org.). Pesquisas sobre utilização e conservação do solo na Amazônia Oriental. Belém: EMBRAPA-CPATU, 1986.

DOPPLER, W. Landwirtschaftliche Betriebssysteme in den Tropen und Subtropen. Stuttgart: Eugen Ulmer Verlag, 1991.

DUBOIS, J. Secondary Forests as a Land-Use Resource in Frontier Zones of Amazonia. In: ANDERSON, A. B. (Ed.). Alternatives to Deforestation: 
Steps towards Sustainable Use of the Amazon Rain Forest. New York: Columbia University Press, 1990.

DUBOIS, J . The Role of Agroforestry in the Sustainable Development of the Amazon. In: PPG-7 (Ed.). Pilot Program to Protect the Brazilian Rain Forests. Bonn, 1996. Report on the Third Meeting of the Participants, Bonn, 10-12 September 1996.

DUBOIS, J.; VIANA, V.; ANDERSON, A. B. Manual agroflorestal para a Amazônia. Rio de J aneiro: REBRAF, 1996, v. 1.

EGLER, E. G. Zona bragantina no Estado do Pará. Rev. Bras. Geogr. , [S.I.], n. 23, p. 527-555, 1961.

ELLIS, F. Peasant Economics: Farm Households and Agrarian Development. Cambridge: Cambridge University Press, 1993.

EMBRAPA-CPATU; GTZ. Pesquisas sobre utilização e conservação do solo na Amazônia Oriental. Belém: EMBRAPA, 1986 (Documento 40).

FALESI, I. C. O solo da Amazônia e sua relação com a definição de sistemas de produção agrícola. Brasília, DF: EMBRAPA/IICA, 1974a (Documento 2).

FALESI, I. C. Soils of the Brazilian Amazon. In: WAGLEY, C. (Ed.). Man in the Amazon. Gainesville: University of Florida Press, 1974b. p. 201-229.

FALESI, I. C. Estado atual de conhecimentos de solos da Amazônia brasileira. In: EMBRAPA-CPATU (Org.). Anais do Primeiro Simpósio do Trópico Úmido. Belém: EMBRAPA-CPATU, 1986. V. I: Clima e Solo.

FALESI, I. C. Efeitos da queima da biomassa florestal nas características do solo da Amazônia. In: COSTA, J. M. M. da (Org.). Amazônia: desenvolvimento ou retrocesso. Belém: Cejup, 1992. p. ...-...

FALESI, I. C.; BAENA, A.; DUTRA, S. Conseqüencias da exploração agropecuária sobre as condições físicas e químicas dos solos das microrregiões do Nordeste paraense. Belém: EMBRAPA-CPATU, 1980 (Boletim de Pesquisa 14).

FAO; INCRA. Diretrizes de política agrária e desenvolvimento sustentável para a pequena produção familiar na região norte. Brasília, DF: Ms., 1995. 
FEARNSIDE, P. M. Agriculture in Amazonia. In: PRANCE, G. T.; LOVEJ OY, T. E. (Ed.). Key Environments: Amazonia. Oxford: Pergamon Press, 1985.

FEARNSIDE, P. M. Human Carrying Capacity of the Brazilian Rainforest. New York: Columbia University Press, 1986.

FEARNSIDE, P. M. An Ecological Analysis of Predominant Land Uses in the Brazilian Amazon. The Environmentalist, v. 8, n. 4, p. 281-300, 1988a.

FEARNSIDE, P. M. O carvão de Carajás. Ciência Hoje, v. 8, n. 48, p. 17$21,1988 \mathrm{~b}$.

FIGUEIREDO, R. B. de. Diagnóstico da agricultura familiar do município de Paragominas-PA. Belém: NAEA/DAZ, 1994.

FITTKAU, E. J . Ökologische Gliederung des Amazonasgebietes auf geochemischer Grundlage. Münster Forsch. Geol. Paläont., Nr. 20/21, S. 3550, 1971.

FLOHRSCHÜTZ, G. Analise econômica de estabelecimentos rurais no município de Tomé Açu, Pará: um estudo de caso. Belém: EMBRAPACPATU, 1983 (Documento 19).

FOWERAKER, J. The Struggle for Land: A Political Economy of the Pioneer Frontier in Brazil from 1930 to the Present Day. Cambridge: Cambridge University Press, 1981.

FRANCO, W.; DEZZEO, N. Soils and Soil Water Regime in the Terra Firme-Caatinga Forest Complex near San Carlos de Rio Negro, State of Amazonas, Venezuela. Interciencia, v. 19, n. 6, p. 305-316, 1994.

GASH, J.; NOBRE, C.; ROBERTS, J.; VICTORIA, R. (Ed.). Amazonian Deforestation and Climate. Chichester, New York: Wiley, 1996.

GIDDENS, A. The Constitution of Society. Cambridge: Polity Press, 1984.

GIDDENS, A. New Rules of Sociological Method, 2. Ausgabe, Cambridge: Polity Press, 1993.

GLERUM, B. B. Pesquisa combinada floresta-solo no Pará-Maranhão. Rio de J aneiro: SPVEA, 1965 (Inventários Florestais na Amazônia, v. 9).

GOUROU, P. Observações geográficas na Amazônia. Rev. Bras. de Geogr., [S.I.], v. 11, n. 3, p. 355-408, 1950. 
GROSSMANN, M. Diversifizierung der kleinbäuerlichen Landwirtschaft: Das Fallbeispiel Capitao Poco im Nordosten von Pará. Ein Weg zum nachhaltigen Landbau in Amazonien? Belém: NAEA, 1995.

HALL, A. Developing Amazonia: Deforestation and Social Conflict in Brazil's Carajás Programme. Manchester: Manchester University Press, 1989.

HÉBETTE, J. A relação pesquisadores-agricultores: diálogo, parceria, aliança? Uma análise estrutural. Agricultura Familiar, [S.I.], v. 1, n. 1, 1996.

HÉBETTE, J .; ACEVEDO, R. Colonização espontánea, política agrária e grupos sociais. In: COSTA, J. M. M. (Org.). Amazônia: desenvolvimento e ocupação. Rio de J aneiro: IPEA/INPES, 1979a.

HÉBETTE, J .; ACEVEDO, R. Colonização para quem? Belém: NAEA/UFPA, 1979b.

HECHT, S. Cattle Ranching in Eastern Amazonia: Environmental and Social Implications. In: MORAN, E. F. (Ed.). The Dilemma of Amazonian Development). Boulder, Col.: Westview Press, 1983. p. 155-188.

HECHT, S. Environment, Development and Politics: Capital Accumulation and the Livestock Sector in Eastern Amazonia. World Development, v. 13, n. 6, p. 663-684, 1985.

HEINSDIJ K, D.; Bastos, A. de M. Inventários florestais na Amazônia. Rio de J aneiro: Ministério de Agricultura/Serviço Florestal, 1963 (Boletim n. 6).

HERRERA, R.; J ORDAN, C.; KLINGE, H.; MEDINA, E. Amazon Ecosystems: Their Structure and Functioning with Particular Emphasis on Nutrients. Interciencia, v. 4, n. 3, p. 223-231, 1978.

HODNETT, M. G.; PIMENTAL DA SILVA, L.; ROCHA, H. R. da; SENNA, R. C. Seasonal Soil Water Storage Changes Beneath Central Amazonian Rain Forest and Pasture. J . of Hydrology, n. 170, p. 233-254, 1995.

HÖLSCHER, D. Wasser- und Stoffhaushalt eines Agrarökosystems mit Waldbrache im östlichen Amazonasgebiet. Göttingen: Universität Göttingen, 1995 (Göttinger Beiträge zur Land- und Forstwissenschaft in den Tropen und Subtropen 106). 
HOMMA, A.; WALKER, R. Land Use and Land Cover Dynamics in the Brazilian Amazon: an Overview. Ecological Economics, v. 18, n. 1, p. 6780, 1996.

HOMMA, A.; WALKER, T.; CARVALHO, R.; FERREIRA, C.; CONTO, A. de; SANTOS, A. dos; SCATENA, F. Dinâmica dos sistemas agroflorestais: o caso dos agricultores nipo-brasileiros em Tomé-Açu (Pará). In: COSTA, J. M. M. da (Org.). Amazônia: desenvolvimento econômico, desenvolvimento sustentável e sustentabilidade de recursos naturais. Belém: Cejup, 1995.

HURTIENNE, T. Ökologie, Ökonomie und Sozialsysteme Amazoniens: Versuch einer kulturökologischen Bilanz (Teil 1). Berlin: Ms, 1988.

HURTIENNE, T. Das Ende eines Mythos? Natur und Kultur in Amazonien. In: STAATLICHE KUNSTHALLE BERLIN (Hrsg.). Klima Global - Arte Amazonas. Berlin, 1993. S. 51-61.

INHETVIN, T. Wo der Pfeffer wächst: Weltmarkt und lokale Produktion im brasilianischen Amazonien, Diplomarbeit am FB Wirtschaftswissenschaften der FU Berlin. Berlin, 1991.

J ANOS, D. P. Tropical Mycorrhizas, Nutrient Cycles and Plant Growth. In: SUTTON, S. L.; WHITMORE, T. C.; CHADWICK, A. C. (Ed.). Tropical Rain Forest: Ecology and Management. Oxford: Blackwell Scientific Publications, 1983.

J ORDAN, C. F. Amazon Rain Forests. American Scientist, v. 70, J uly/ Aug. 1982.

J ORDAN, C. F. Nutrient Cycling in Tropical Forest Ecosystems. Chichester: Wiley, 1985a.

J ORDAN, C. F. Soils of the Amazon Rainforest. In: PRANCE, G. T.; LOVEJ OY, T. E. (Ed.). Key Environments: Amazonia. Oxford: Pergamon Press, 1985b.

J ORDAN, C. F. (Ed.). Amazonian Rain Forests: Ecosystem Disturbance and Recovery. Case Studies of Ecosystem Dynamics under a Spectrum of Land-Use Intensities. New York: Springer; Berlin: Heidelberg, 1987a.

J ORDAN, C. F. Shifting Cultivation: Slash and Burn Agriculture near San Carlos de Rio Negro, Venezuela. In: J ORDAN, C. F. (Ed.). Amazoni- 
an Rain Forests: Ecosystem Disturbance and Recovery. New York: Springer, 1987b. p. 9-23.

J ORDAN, C. F. (Ed.). An Amazonian Rain Forest: The Structure and Function of a Nutrient Stressed Ecosystem and the Impact of Slash-And-Burn Agriculture. Paris: UNESCO, 1989 (Man and the Biosphere Series, v. 2).

KITAMURA, P. Agricultura migratória na Amazônia: um sistema de produção viável. Belém: EMBRAPA-CPATU, 1982 (Documento 12).

KITAMURA, P. A Amazônia e o desenvolvimento sustentável. Brasília: EMBRAPA-SPI, 1994.

KITAMURA, P.; HOMMA, A.; FLOHRSCHÜTZ, G.; SANTOS, A. dos. A pequena agricultura no Nordeste paraense. Belém: EMBRAPA, 1983.

KLINGE, H. Root Mass Estimation in Lowland Tropical Rain Forests of Central Amazonia, Brazil. I. Fine Root Masses of a Pale Yellow Latosol and a Giant Humus Podzol. Tropical Ecology, v. 14, n. 11, p. 2938, 1973a.

KLINGE, H. Root Mass Estimation. II. 'Coarse Root Mass' of Trees and Palms in Different Height Classes. Annales Academia Brasileira de Ciencias, v. 45, n. 3/4, p. 595-609, 1973b.

KLINGE, H. Struktur und Artenreichtum des zentralamazonischen Regenwaldes. Amazoniana, Nr. 4, S. 283-292, 1973c.

KLINGE, H. Bilanzierung von Hauptnährstoffen im Ökosystem tropischer Regenwald (Manaus). Biogeographica, Nr. 7, S. 59-76, 1976a.

KLINGE, H. Nährstoffe, Wasser und Durchwurzelung von Podsolen und Latosolen unter tropischem Regenwald bei Manaus/Amazonien. Biogeographica, Nr. 7, S. 45-58, 1976b.

KLINGE, H.; ADIS, J.; FURCH, K.; J UNK, W. J . Algunos elementos básicos del ecosistema amazónico. In: KOH LHEPP, G.; SCHRADER, A. (Org.). Homem e natureza na Amazônia. Tübingen: Geographisches Institut der Universität Tübingen, 1987.

KLINGE, H.; BRÜNIG, E.; FITTKAU, E. J. Biomass and Structure in a Central Amazonian Rainforest. In: GOLLEY, F. B.; MEDINA, E. (Ed.). Tropical Ecological Systems. New York: Springer, 1975. p. 115-122. 
KLINGE, H.; FITTKAU, E. J . Filterfunktionen im Ökosystem des zentralamazonischen Regenwaldes. Mitt. deutsche bodenkundl. Ges., Nr. 16, S. 130-135, 1972.

KLINGE, $\mathrm{H}$. et al. Biomass and Structure in a Central Amazonian Rain Forest. In: GOLLEY, F. B.; MEDINA, E. (Ed.). Tropical Ecological Systems. New York: Springer, 1975.

KÖPPEN, W. Grundriß der Klimakunde. Berlin: Leipzig, 1931.

LARCHER, W. Ökophysiologie der Pflanzen. Stuttgart: Eugen Ulmer, 1994.

LIPTON, M. The Theory of Optimising Peasant. J ournal of Development Studies, v. 4, n. 3, p. 327-351, 1968.

MAHAR, D. Desenvolvimento econômico da Amazônia: uma analise das políticas governamentais. Rio de J aneiro: IPEA/INPES, 1978.

MARTINE, G. Rondônia and the Fate of small farmers. In: GOODMAN, D.; HALL, A. (Ed.). The Future of Amazonia: Destruction or Sustainable Development? London: Macmillan, 1990.

MATTOS, A.; UHL, C. Economic and Ecological Perspectives on Ranching in the Eastern Amazon. World Development, v. 22, n. 2, 1994.

MAZOYER, M. Dynamique des systèmes agraires. Paris: Ministère de la Recherche et de la Technologie, 1987. Rapport de synthèse du colloque sur la dynamique des systèmes agraires.

MEDINA, E.; CUEVAS, E. Biomass Production and Accumulation in Nutrient-Limited Rain Forests: Implications for Responses to Global Change. In: GASH, J .; NOBRE, C.; ROBERTS, J .; VICTORIA, R. (Ed.). Amazonian Deforestation and Climate. Chichester, New York: Wiley, 1996.

MEGGERS, B. Environmental Limitations on the Development of Culture. American Anthropologist, n. 56, p. 801-824, 1954.

MEGGERS, B. Amazonia. Chicago: Aldine, 1971.

MORAN, E. F. Developing the Amazon. Bloomington: Indiana University Press, 1981. 
MORAN, E. F. Through Amazonian Eyes: The Human Ecology of Amazonian Populations. Iowa: University of Iowa Press, 1993.

MORAN, E. F.; PACKER, A.; BRONDIZIO, E.; TUCKER, J. Restoration of Vegetation Cover in the Eastern Amazon. Ecological Economics, v. 18, n. 1, p. 41-54, 1996.

NATIONAL RESEARCH COUNCIL (Ed.). Sustainable Agriculture and the Environment in the Humid Tropics. Washington, D.C.: National Academy Press, 1993.

NASCIMENTO, C.; HOMMA, A. Amazônia: meio ambiente e tecnología agrícola. Belém: EMBRAPA-CPATU, 1984 (Documento 27).

NEPSTAD, D. et al. The Role of Deep Roots in the Hydrological and Carbon Cycles of Amazonian Forests and Pastures. Nature, n. 372, p. 666-669, 1994.

NEPSTAD, D.; UHL, C.; PEREIRA, C.; SILVA, J . da. A Comparative Study of Tree Establishment in Abandoned Pasture and Mature Forest of Eastern Amazonia. Oikos, v. 75, n. 1, 1996.

NEPSTAD, D.; UHL, C.; SERRÃO, E. A. S. Recuperation of a Degraded Landscape: Forest Recovery and Agricultural Restoration. Ambio, n. 20, p. 248-255, 1991.

NICHOLAIDES, J . J. et al. Crop Production Systems in the Amazon Basin. In: MORAN, E. F. (Ed.). The Dilemma of Amazonian Development. Boulder, Col.: Westview Press, 1983.

NITSCH, M. Sinn und Unsinn von Rotationsfonds in der Kleingewerbeund Kleinbauernförderung - ein Beispiel für angewandte Institutionenökonomik. Berlin: Lateinamerika-Institut der FU Berlin (Sonderdruck), 1991.

NITSCH, M. Kleinbauern in Amazonien: Das Erfolgsrezept von Uraim. Lateinamerika. Analysen-Daten-Dokumentation, Nr. 19, S. 55-64, 1992.

NITSCH, M.; KASPER, A. Pequenos produtores na Zona Bragantina: uma abordagem sócio-econômica à análise ecossistêmica do uso da terra e do manejo da capoeira no município de Igarapé Açu. Beitrag für den SHIFT-Workshop in Cuiabá vom 14.-18.7.1995. Papier für den SHIFTWorkshop in Cuiabá, 10.-14. J uli 1995. Berlin: Ms, 1996. 
NOBRE, C.; SELLERS, P.; SHUKLA, J. Amazonian Deforestation and Regional Climate Change. J. Climate, n. 4, p. 957-988, 1991.

NORGAARD, R. Sociosystem and Ecosystem Coevolution in the Amazon. J ournal of Environmental Economics and Management, n. 8, p. 238$254,1981$.

ODUM, E. P. Prinzipien der Ökologie. Lebensräume, Stoffkreisläufe, Wachstumsgrenzen. Heidelberg, 1991.

PAET (Programa Agro-Ecológico da Transamazônica). 0 futuro da agricultura familiar na Transamazônica. Altamira, 1994.

PANDOLFO, C. A floresta amazônica brasileira: enfoque econômico-ecológico. Belém: SUDAM, 1978.

PANDOLFO, C. Amazônia brasileira: ocupação, desenvolvimento e perspectivas atuais e futuras. Belém: Cejup, 1994.

PARKER, E. The Amazon Caboclo: An Introduction and Overview. In: PARKER, E. (Ed.). The Amazon Caboclo: Historical and Contemporary Perspectives. Williamsburg, Va.: Department of Anthropology, College of William and Mary, 1985, p. 1-49 (Studies in Third World Societies, v. 32).

PENTEADO, A. R. Problemas de colonização e uso da terra na região bragantina do Estado do Pará, 2 Bde., Diss. Belém: Universidade Federal do Pará, 1967.

PIRES, J . M. The Forest Ecosystems of the Brazilian Amazon: Description, Functioning and Research Needs. In: UNESCO (Ed.). Tropical Forest Ecosystems: A Stae-of-Knowledge Report. Nat. Res. Res. No. 14, 1978.

PIRES, J . M.; DOBZHANSKY, T.; BLACK, G. A. An Estimate of the Number of Trees in an Amazonian Forest Community. Bot. Gaz., n. 114, p. 467-477. 1953.

PIRES, J . M.; PRANCE, G. T. The Vegetation Types of the Brazilian Amazon. In: PRANCE, G. T.; LOVEJ OY, T. E. (Ed.). Key Environments: Amazonia. Oxford: Pergamon Press, 1985.

POELS, R. Soils, Water and Nutrients in a Forest Ecosystem in Suriname. Wageningen: Agric. Univ. Wageningen, 1987. 
POELS, R. The Use of the Tropfor Model to Simulate Growth and Water Use of Tropical Rain Forests. Interciencia, v. 19, n. 6, p. 386-398, 1994.

PRINZ, D. Erhaltung und Verbesserung der landwirtschaftlichen Produktivität in den Tropen und Subtropen. In: REHM, S. (Hrsg.). Grundlagen des Pflanzenbaues in den Tropen und Subtropen. Handbuch der Landwirtschaft und Ernährung in den Entwicklungsländern, Bd. 3. Stuttgart: Eugen Ulmer, 1986.

REICHHOLF, J. H. Der tropische Regenwald. Die Ökobiologie des artenreichsten Naturraums der Erde. München: dtv, 1990.

REIJ NTJ ES, C.; HAVERKORT, B.; WATERS-BAYER, A. Agricultura para o futuro: uma introdução à agricultura sustentável e de baixo uso de insumos externos. Rio de J aneiro: ASPTA/ILEIA, 1994.

REYNAL, V. de; MUCHAGATA, A. G.; TOPALL, O.; HÉBETTE, J . Agriculturas familiares e desenvolvimento em frente pioneira amazônica. Belém: LASAT/CAT, 1996.

RICHARDS, P. W. The Tropical Rain Forest: An Ecological Study. Cambridge: Cambridge University Press, 1952.

RICHARDS, P. W. The Tropical Rain Forest. Scientific American, n. 229, 1973.

RICHARDS, P. W. Tropical Forests and Woodlands: An Overview. AgroEcosystems, n. 3, p. 225-238, 1977.

ROOSEVELT, A. Parmana: Prehistoric Maize and Maniok Subsistence Along the Amazon and Orinoco. New York: Academic Press, 1980.

RUTHENBERG, H. Farming Systems in the Tropics. Oxford: Clarendon Press, 1980.

RUTHENBERG, H.; ANDREAE, B. Landwirtschaftliche Betriebssysteme in den Tropen und Subtropen. In: VON BLANCKENBURG, P. (Hrsg.). Handbuch der Landwirtschaft und Ernährung in den Entwicklungsländern, Bd. 1: Sozialökonomie der ländlichen Entwicklung, Stuttgart: Eugen Ulmer, 1982.

SALATI, E.; VOSE, P. Amazon Basin: A System in Equilibrium. Science, n. 225, p. 129-138, 1984. 
Thomas Hurtienne

SALOMÃO, R.; NEPSTAD, D.; VIEIRA, I. Como a biomassa de florestas tropicais influi no efeito estufa? Ciência hoje, v. 21, n. 123, p......., 1996.

SANCHEZ, P. A. Properties and Management of Soils in the Tropics. New York, London: J ohn Wiley \& Sons, 1976.

SANTANA, A. Diagnóstico sócio-econômico da pequena agricultura de Igarapé Açu. Belém: FCAP, 1990. Relatório de pesquisa.

SANTANA, A. Análise da pequena produção agrícola em comunidades da Amazônia. Belém: FCAP, BASA, 1995 (Caderno sócio-economico, n. 1).

SAWYER, D. Colonização da Amazônia: migração de nordestinos para uma frente agrícola no Pará. R. Econ. Nord., v. 10, n. 3, p. 773-812, 1979a.

SAWYER, D. Peasants and Capitalism on an Amazon Frontier. Cambridge, Mass.: Harvard University Press, 1979b. PhD Thesis.

SCHIMPER, A. Plant Geography upon a Physiological Basis. Oxford: P. Groom \& I. B. Balfour, 1903.

SCHMIDT, J. C. $O$ clima da Amazônia. Rev. Bras. de Geogr., v. 4, n. 3, p. 3-38, 1947.

SCHNEIDER, R. Government and the Economy on an Amazon Frontier. Washington, D.C.: World Bank, 1995.

SERRÃO, E. A. S. Desenvolvimento agropecuário e florestal na Amazônia. In: COSTA, J. M. M. da (Org.). Amazônia: desenvolvimento econômico, desenvolvimento sustentável e sustentabilidade de recursos naturais. Belém: Cejup, 1995a.

SERRÃO, E. A. S. Possibilitiesfor Sustainable Agriculture Development in the Brazilian Amazon: An EMBRAPA Proposal. In: CLÜSENER-GODT, M.; SACHS, I. (Ed.). Brazilian Perspectives on Sustainable Development of the Amazon Region. Paris: UNESCO, 1995b. (Man and the Biosphere Series, v. 15).

SERRÃO, E. A. S.; HOMMA, A. Brazil Country Profile. In: NATIONAL RESEARCH COUNCIL (Ed.). Sustainable Agriculture and the Environment in the Humid Tropics. Washington, D.C.: National Academy Press, 1993. 
SHUKLA, J .; NOBRE, C.; SELLERS, P. Amazon Deforestation and Climate Change. Science, n. 247, p. 1322-1325, 1990.

SIOLI, H. Estudo preliminar das relações entre a geologia e a limnologia da Zona Bragantina. Belém: IAN, 1951 (Bol. Técn. 24).

SIOLI, H. Über Natur und Mensch im brasilianischen Amazonasgebiet. Erdkunde, Bd. X, H. 2, 1956.

SIOLI, H. Pesquisas limnológicas na região da estrada de ferro de Bragança, Estado do Pará, Brasil. IAN Bol. Técn., n. 37, p. 1-91, 1960.

SIOLI, H. Recent Human Activities in the Brazilian Amazon Region and Their Ecological Effects. In: MEGGERS, B. J.; AYENSU, E. S.; DUCKWORTH, W. D. (Ed.). Tropical Forest Ecosystems in Africa and South America: A Comparative Revue. Washington, D.C.: Smithsonian Inst. Press, 1973.

SIOLI, H. Amazonien: Grundlagen der Ökologie des größten tropischen Waldlandes. Stuttgart: Wissenschaftliche Verlagsgesellschaft, 1983.

SIOLI, H. Former and Recent Utilizations of Amazonia and Their Impact on the Environment. In: SIOLI, H. (Ed.). The Amazon: Limnology and Landscape Ecology of a Mighty Tropical River and Its Basin. Dordrecht, Boston, Lancaster: W. J unk, 1984a.

SIOLI, H. Present 'Development' of Amazonia in the Light of the Ecological Aspect of Life, and Alternative Concepts. In: SIOLI, H. (Ed.). The Amazon: Limnology and Landscape Ecology of a Mighty Tropical River and Its Basin. Dordrecht, Boston, Lancaster: W. J unk, 1984b.

SIOLI, H. (Ed.). The Amazon: Limnology and Landscape Ecology of a Mighty Tropical River and Its Basin. Dordrecht, Boston, Lancaster: W. J unk, 1984c.

SIOLI, H. Unifying Principles of Amazonian Landscape Ecology and Their Implications. In: SIOLI, H. (Ed.). The Amazon: Limnology and Landscape Ecology of a Mighty Tropical River and Its Basin. Dordrecht, Boston, Lancaster: W. J unk, 1984d.

SMITH, N. Rainforest Corridors: The Transamazon Colonization Scheme. Berkeley: University of California Press, 1982. 
SOARES, L. de C. Limites meridionais e orientais de ocorrência da floresta amazônica em território brasileiro. Rev. Bras. de Geogr., v. 15, n. 1, p. 3-122, 1953.

SOMBROEK, W. Amazon Soils. Wageningen: Centre for Agricultural Publications and Documentation, 1966.

SOUSA FILHO, F. R. Agricultura familiar: a dinâmica histórica de sua reprodução na fronteira agrária da Amazônia. Belém: NAEA, 1997.

STARK, N; J ORDAN, C. F. Nutrient Retention by the Root Mat of an Amazonian Rain Forest. Ecology, n. 59, p. 434-437, 1978.

STEINER, K. G. Intercropping in Tropical Smallholder Agriculture with Special Reference to West Africa. Eschborn: GTZ, 1982 (Schriftenreihe Nr. 137).

SUBLER, S. Mechanisms of Nutrient Retention and Recycling in a Chronosequence of Amazonian Agroforestry Systems: Steps Toward Sustainable Use of the Amazon Rain Forest. Pennsylvania: The Pennsylvania State University, 1993. PhD Diss.

SUBLER, S.; UHL, C. J apanese Agroforestry in Amazonia: A Case Study in Tomé Acu. In: ANDERSON, A. (Ed.). Alternatives to Deforestation: Steps Towards Sustainable Use of the Amazon Rain Forest. New York: Columbia University Press, 1990.

SUDAM. Projeto de hidrologia e climatologia da Amazônia. Belém, 1984.

TEPICHT, J. Marxisme et agriculture: le paysan polonais. Paris: Armand Colin, 1973.

TIESSEN, H.; CUEVAS, E.; CHACÓN, P. The Role of Soil Organic Matter in Sustaining Soil Fertility. Nature, n. 371, p. 783-785, 1994.

TONIOLO, A.; UHL, C. Perspectivas economicas e ecológicas da agricultura na Amazônia Oriental. In: ALMEIDA, O. T. (Org.). A evolução da fronteira amazônica: oportunidades para um desenvolvimento sustentável. Belém: IMAZON, 1996.

TSCHAJ ANOW, A. Die Lehre von der bäuerlichen Wirtschaft: Versuch einer Theorie der Familienwirtschaft im Landbau. Berlin: Paul Parey, 1923. 
UHL, C. You Can Keep a Good Forest Down. How much abuse can Amazonian Rain Forests Take and Still Recover? Natural History, n. 4, p. 7179, 1983.

UHL, C.; J ORDAN, C. F.; CLARK, K.; CLARK, H.; HERRERA, R. Ecosystem Recovery in Amazon Caatinga Forest after Cutting, Cutting and Burning, and Bulldozer Clearing Treatments. Oikos, n. 38, p. 313-320, 1982.

UHL, C. et al. Studies of Ecosystem Response to Natural and Anthropogenic Disturbances Provide Guidelines for Designing Sustainable LandUse Systems in Amazonia. In: ANDERSON, A. B. (Ed.). Alternatives to Deforestation: Steps toward Sustainable Use of the Amazon Rain Forest. New York: Columbia University Press, 1990.

VEIGA, J . B. da; TOURRAND, J .-F.; QUANZ, D. A pecuária na fronteira agrícola da Amazônia: o caso do município de Uruará-PA na Transamazônica. Belém: EMBRAPA-CPATU, 1995.

VELHO, O. Capitalismo autoritário e campesinato. São Paulo, Rio de J aneiro: Difel, 1976.

VIEIRA, I. Forest Succession after Shifting Cultivation in Eastern Amazonia. Stirling: University of Stirling, 1996. PhD Thesis.

VIEIRA, I.; SALOMÃO, R.; NEPSTAD, D.; ROMA, J . O renascimento da floresta no rastro da agricultura: como a floresta amazônica sobrevive ao desmatamento e às queimadas. Ciência Hoje, v. 20, n. 119, 1996.

VLEK, P.; FÖLSTER, H. Sekundärwald und Brachevegetation in der Kulturlandschaft des östlichen Amazonasgebietes - Funktion und Manipulierbarkeit, SHIFT-Verlängerungsantrag (1995-1999). Göttingen: Universität Göttingen, 1994.

WAGLEY, C. Amazon Town. New York: Macmillan, 1953.

WALTER, H. Vegetation of the Earth in Relation to Climate and the Ecophysiological Conditions. New York: Springer, 1973.

WALTER, H.; BRECKLE, S.-W. Ökologie der Erde. Bd. 2. Spezielle Ökologie der tropischen und subtropischen Zonen. Stuttgart: Gustav Fischer, 1984.

WEISCHET, W. Die ökologische Benachteiligung der Tropen. Stuttgart: B.G. Teubner, 1980. 
WEISCHET, W.; CAVIEDES, C. The Persisting Ecological Constraints of Tropical Agriculture. Essex: Longman Scientific \& Technical; New York: Wiley, 1993.

WENT, F. W.; STARK, N. Mycorrhiza. BioScience, n. 18, p. 1035-1039, 1968.

WHITMORE, T. C. Tropical Rainforests of the Far East. Oxford: Clarendon Press, 1975.

WHITMORE, T. C. Tropische Regenwälder. Eine Einführung. Heidelberg: Spektrum, 1993.

WIESENMÜLLER, J .; DENICH, M.; VLEK, P. Dynamics of Root Development in Fallow Vegetatoin in Eastern Amazonia, Brazil. In: GERMAN/ BRAZILIAN COOPERATION IN ENVIRONMENTAL RESEARCH AND TECHNOLOGY, CNPq, IBAMA, BMBF, DLR (Ed.). Summaries of Lectures and Posters Presented at the Second SHIFT-Workshop Cuiabá, J uly 10-14, 1995. Cuiabá, 1995.

WORLD BANK. Brazil: An Analysis of Environmental Problems in the Amazon. Washington, D.C.: World Bank, Country Operations Division, Brazil Department, 1992.

WORLD BANK; BRAZIL. World Bank Pilot Program Coordination. The Brazil Rain Forest Pilot Program: Lessons Learned and Implications for the Years to Come. In: PPG7. Pilot Program To Protect The Brazilian Rain Forests. Report on the Third Meeting of the Participants. Bonn, 10-12 September 1996. Bonn, 1996.

WRIGHT, I. R.; GASH, J .; ROCHA, H. da; ROBERTS, J. Modelling Surface Condactance for Amazonian Pasture and Forest. In: GASH, J .; NOBRE, A.; ROBERTS, J.; VICTORIA, R. (Ed.). Amazonian Deforestation and Climate. New York: Wiley, 1996. 